\title{
Cultural Resources Inventory at Lake Corpus Christi State Park, San Patricio County, Texas
}

Carole Leezer

Center for Archaeological Studies

Follow this and additional works at: https://scholarworks.sfasu.edu/ita

Part of the American Material Culture Commons, Archaeological Anthropology Commons, Environmental Studies Commons, Other American Studies Commons, Other Arts and Humanities Commons, Other History of Art, Architecture, and Archaeology Commons, and the United States History Commons

Tell us how this article helped you.

This Article is brought to you for free and open access by the Center for Regional Heritage Research at SFA ScholarWorks. It has been accepted for inclusion in Index of Texas Archaeology: Open Access Gray Literature from the Lone Star State by an authorized editor of SFA ScholarWorks. For more information, please contact cdsscholarworks@sfasu.edu. 


\section{Cultural Resources Inventory at Lake Corpus Christi State Park, San Patricio}

County, Texas

\section{Creative Commons License}

\section{(c) (i) (9)}

This work is licensed under a Creative Commons Attribution-NonCommercial 4.0 International License 
Cultural Resources Inventory at Lake Corpus Christi State Park, San Patricio County, Texas

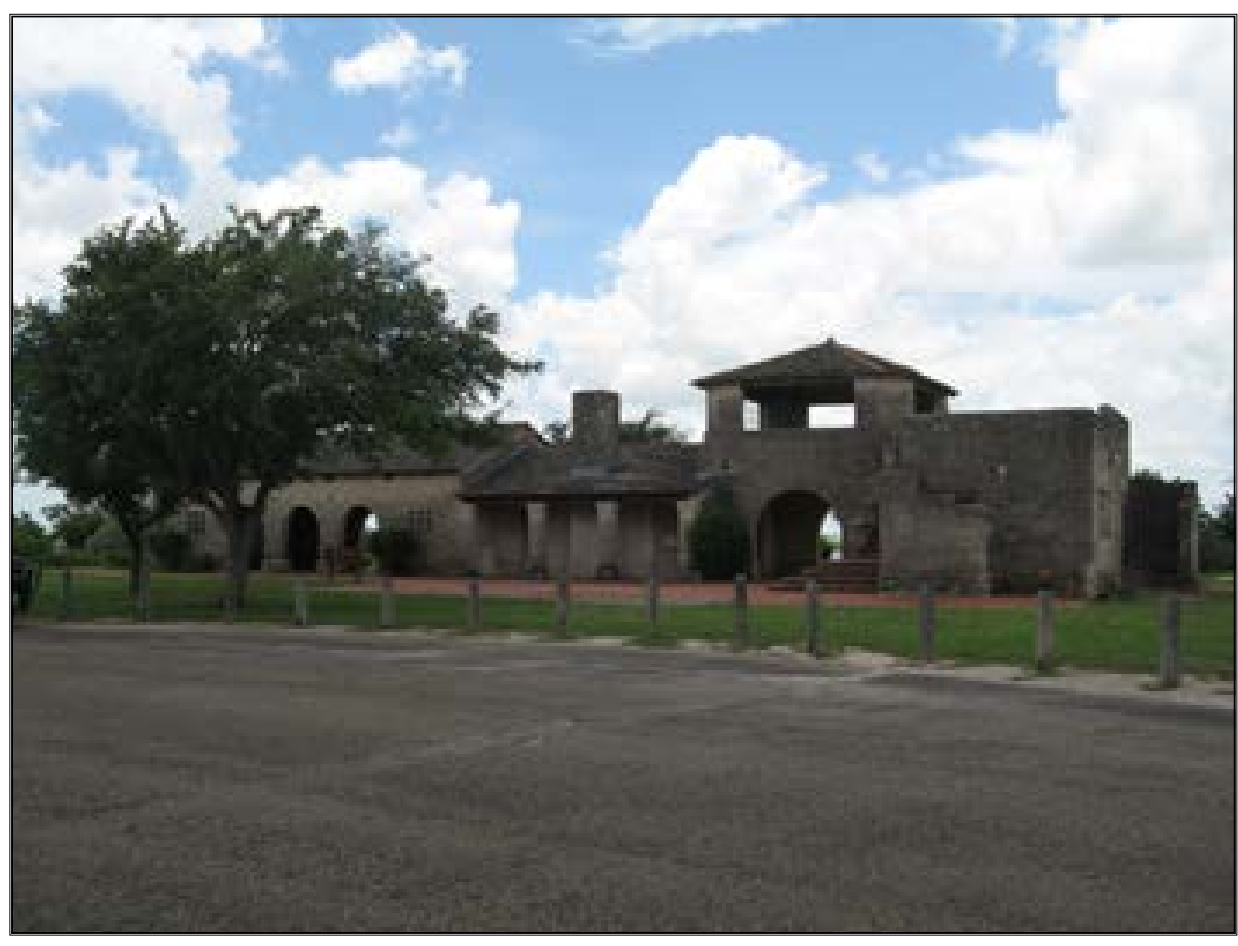

By

Carole Leezer

Principal Investigator: Carole Leezer

Archaeological Studies Report No. 21

Texas Antiquities Permit 5652 


\title{
Cultural Resources Inventory at Lake Corpus Christi State Park, San Patricio County, Texas
}

\author{
by \\ Carole Leezer \\ Principal Investigator: Carole Leezer
}

Texas Antiquities Permit 5652

Prepared for:

Texas Parks and Wildlife Department Cultural Resources Program

Archaeological Studies Report No. 21

Center for Archaeological Studies

Texas State University-San Marcos 
The following information is provided in accordance with the General Rules of Practice and Procedures, Title 13, Chapter 26, Texas Administrative Code:

1. Type of investigation: A cultural resources inventory at Lake Corpus Christi State Park, San Patricio County, Texas, consisting of pedestrian survey augmented by shovel test excavations.

2. Project name: Cultural Resources Inventory at Lake Corpus Christi State Park, San Patricio County, Texas

3. County: San Patricio

4. Principal Investigator: Carole Leezer

5. Name and location of sponsoring agency: Texas Parks and Wildlife Department, Cultural Resources Program

6. Published by the Center for Archaeological Studies, Texas State University-San Marcos, 601 University Drive, San Marcos, Texas, 78666-4616 (2011)

Texas State University-San Marcos is a member of the Texas State University System Copyright (C) 2011 by the Center for Archaeological Studies at Texas State University-San Marcos

All rights reserved.

No part of this book may be reproduced or utilized in any form or by any means, electronic or mechanical, including photocopying, recording, or by any information storage and retrieval system without permission in writing.

For further information on this and other publications by the Center for Archaeological Studies, please contact:

Center for Archaeological Studies

Texas State University-San Marcos

601 University Drive

San Marcos, TX 78666-4616

www.txstate.edu/anthropology/cas/

Editor: Maggie McClain

Cover Photograph: Refectory Building, Lake Corpus Christi State Park.

Printed in the United States of America

by

Ginny's Printing Inc., Austin

TPWD receives federal assistance from the U.S. Fish and Wildlife Service and other federal agencies and is subject to Title VI of the Civil Rights Act of 1964, Section 504 of the Rehabilitation Act of 1973, Title II of the Americans with Disabilities Act of 1990, the Age Discrimination Act of 1975, Title IX of the Education Amendments of 1972, and state anti-discrimination laws which prohibit discrimination the basis of race, color, national origin, age, sex or disability. If you believe that you have been discriminated against in any TPWD program, activity or facility, or need more information, please contact Civil Rights Coordinator for Public Access,

U.S. Fish and Wildlife Service, 4401 N. Fairfax Drive, Mail Stop: MBSP-4020, Arlington, VA 22203. 


\section{Management Summary}

PROJECT TITLE: Cultural Resources Inventory at Lake Corpus Christi State Park, San Patricio County, Texas

PROJECT DESCRIPTION: A cultural resources inventory of prehistoric and historic sites within the park for the purpose of identifying and evaluating previously unrecorded and previously recorded archeological sites.

SPONSOR: Texas Parks and Wildlife Department, Cultural Resources Program

LOCATION: Lake Corpus Christi State Park, San Patricio County, Texas

PRINCIPAL INVESTIGATOR: Carole Leezer

PROJECT ARCHAEOLOGIST: Carole Leezer

CREW MEMBERS: Julian A. Sitters, Sarah Scogin, Robert Z. Seldon, and Jacob Hooge

INSTITUTION: Center for Archaeological Studies, Texas State University-San Marcos

TEXAS ANTIQUITIES PERMIT: 5652

DATES OF WORK: June 7, 2010 to June 18, 2010

MAN HOURS: 320

TOTAL ACREAGE EVALUATED: 368 acres

PURPOSE OF WORK: Survey results will be used to determine National Register of Historic Places and State Archeological Landmark eligibility status of the newly identified and reassessed cultural resources. Resulting data will also be used by TPWD to address long-term stewardship and management of the resources, and to augment a detailed cultural resources management plan for Lake Corpus Christi State Park.

\section{NUMBER OF SITES: 7}

CURATION: Texas Parks and Wildlife Department

COMMENTS: Five previously recorded sites (41SP116, 41SP178, 41SP202, 41SP227, and 41SP228) were reassessed and two new sites (41SP234 and 41SP235) were recorded. Three possible Civilian Conservation Corps (CCC)-era features were also identified (water tower, culvert, and road segment). Specific management priorities and recommendations for management practices are provided for each archaeological site and identified CCC feature. 


\section{Abstract}

At the request of the Texas Parks and Wildlife Department (TPWD), Cultural Resources Program, archaeologists from the Center for Archaeological Studies at Texas State University-San Marcos conducted a cultural resources inventory at Lake Corpus Christi State Park, San Patricio County, Texas. Field investigations were conducted between June 7 and 18, 2010, under Texas Antiquities Permit No. 5652. Carole Leezer served as Principal Investigator, and the field crew of consisted of Julian A. Sitters, Robert Z. Seldon, Sarah Scogin, and Jacob Hooge. CAS archaeologists conducted a pedestrian survey and excavated 128 shovel test units within the 368-acre project area. This cultural resources inventory identified and evaluated five previously recorded sites (41SP116, 41SP178, 41SP202, 41SP227, and 41SP228), two newly recorded sites (41SP234 and 41SP235), and three possible Civilian Conservation Corps (CCC) features (a water tower, a culvert, and a road segment). Investigations were conducted with the goal of determining eligibility status for nomination to the National Register of Historic Places (NRHP) and designation as a State Archeological Landmark (SAL). Resulting data will also be used by TPWD to address long-term stewardship and management of the resources, and to augment a detailed resource management plan for Lake Corpus Christi State Park. Additional testing investigations are recommended for sites 41SP178, 41SP228, and 41SP234 to aid in the determination of eligibility for NRHP/SAL nomination. Site 41SP227 is recommended for SAL status due to the high likelihood of current and future vandalism and looting at this site. The potential for the newly identified CCC features to be recommended for NRHP nomination and for listing as an SAL is currently unknown. 


\section{Table of Contents}

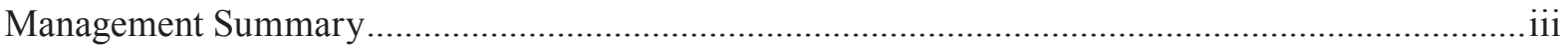

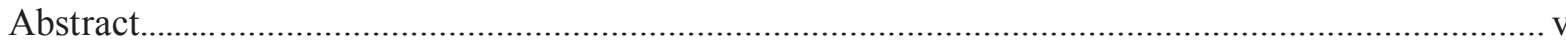

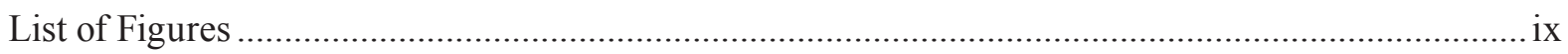

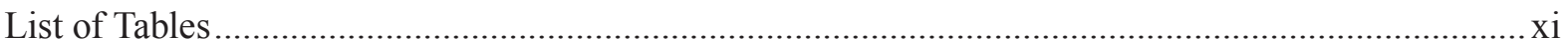

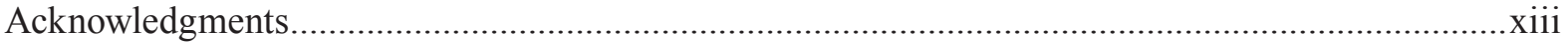

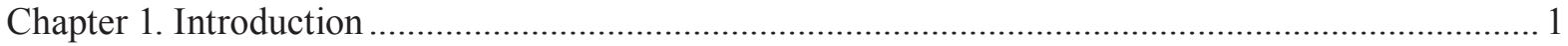

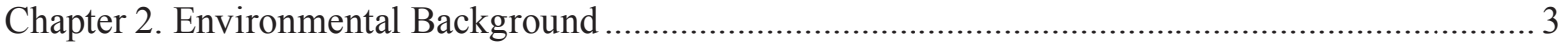

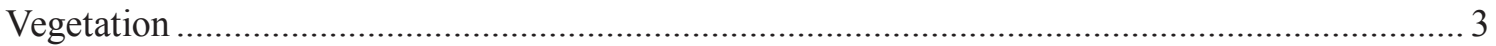

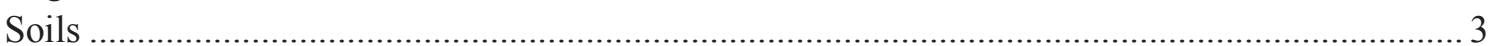

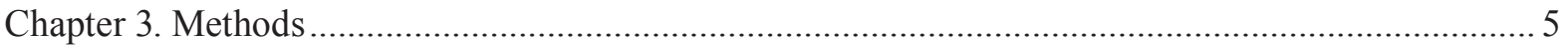

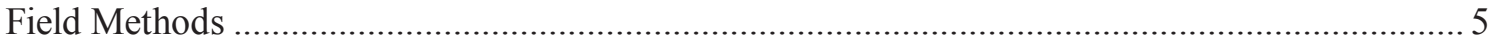

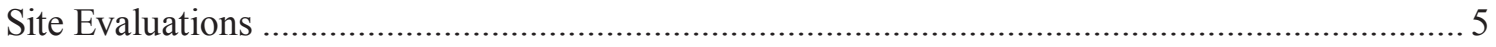

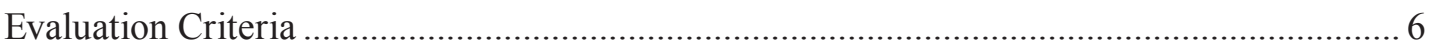

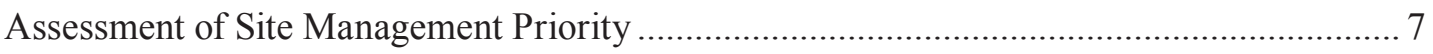

Laboratory Procedures and Curation Preparation.................................................................... 7

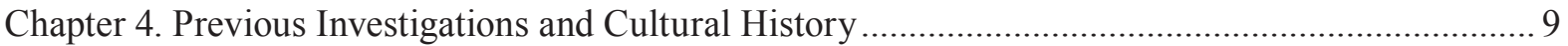

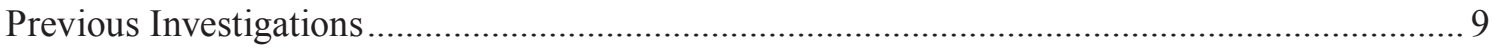

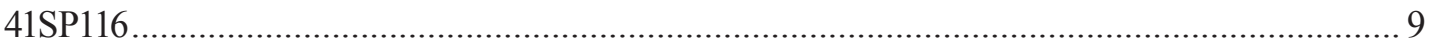

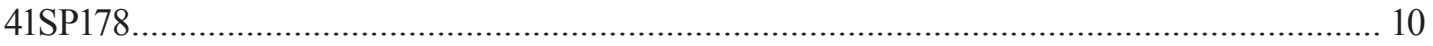

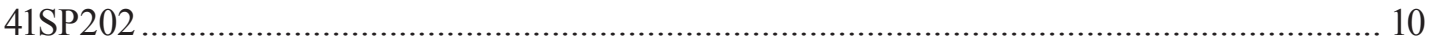

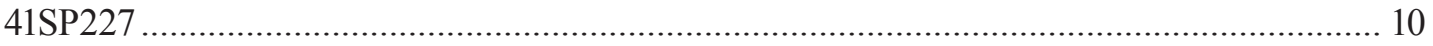

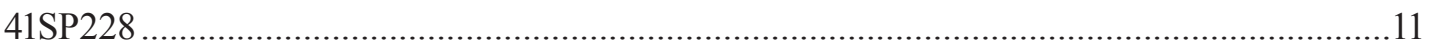

Inventoried/Assessed Civilian Conservation Corps Structures ...........................................11

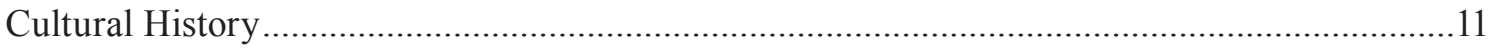

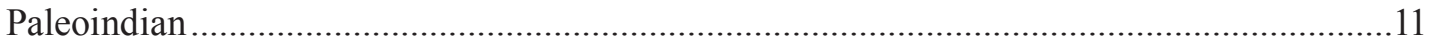

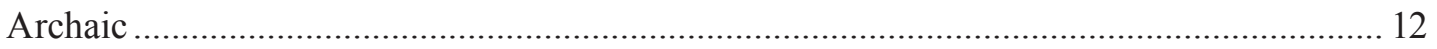

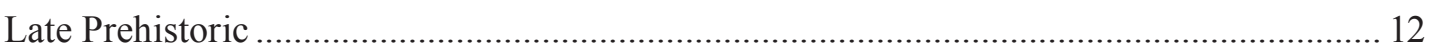

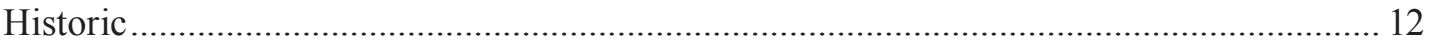

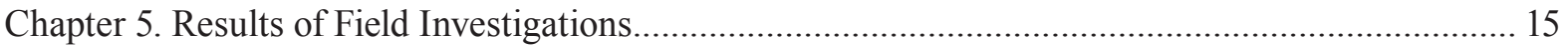

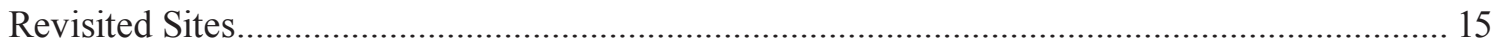

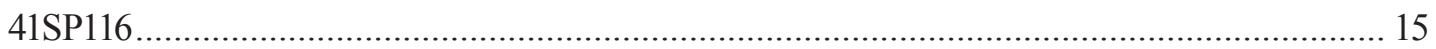

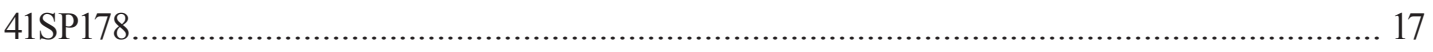

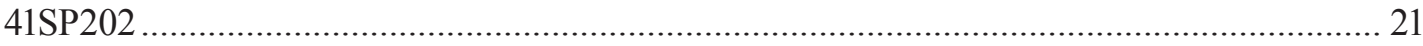

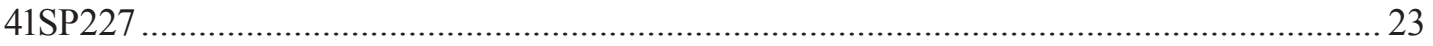

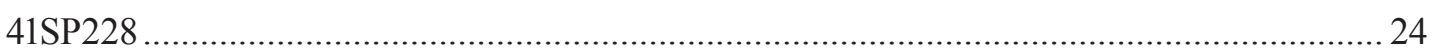

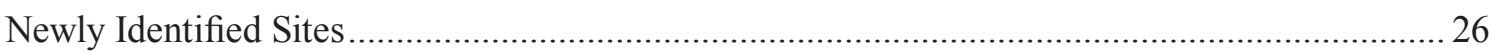

41SP235 26

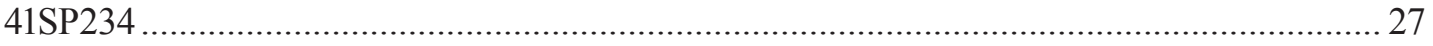

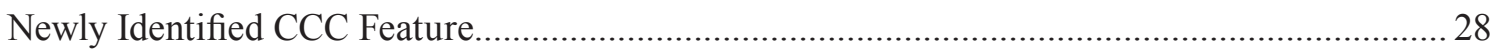




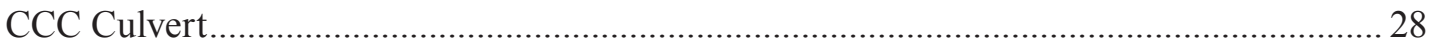

Investigations of Possible CCC Features ............................................................................. 30

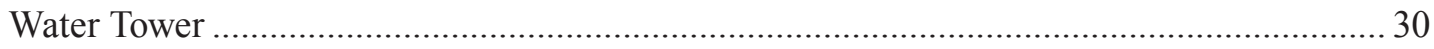

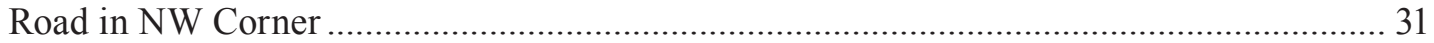

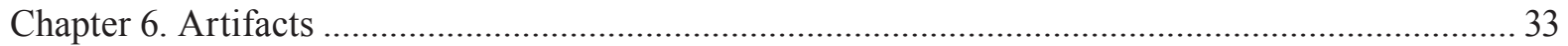

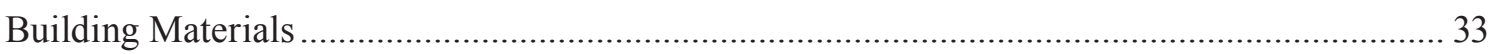

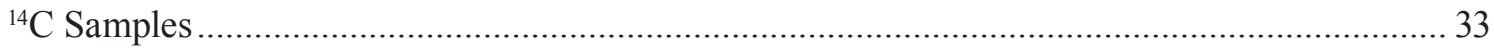

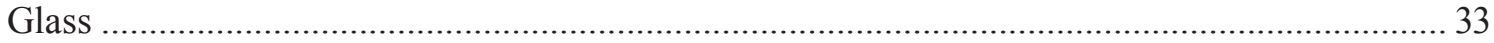

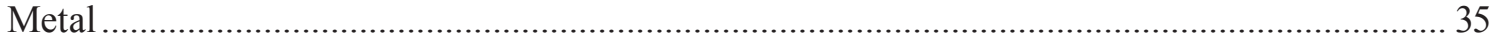

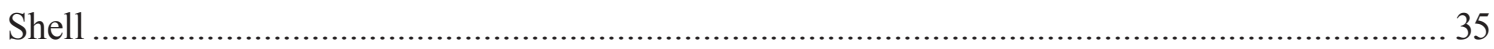

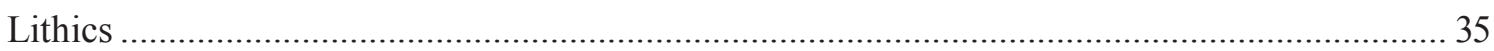

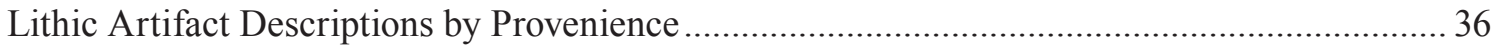

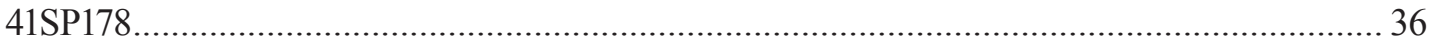

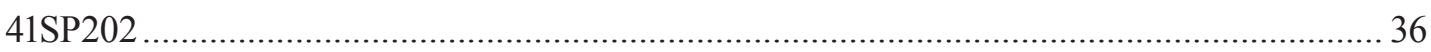

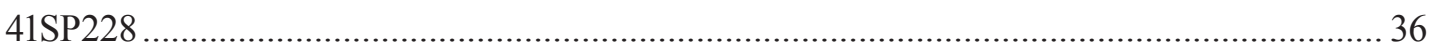

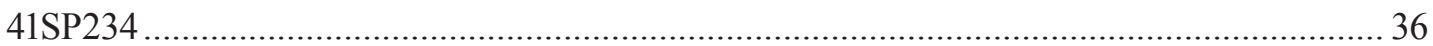

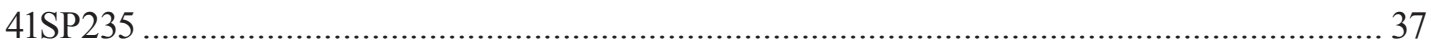

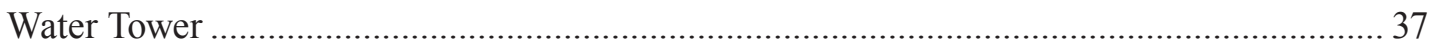

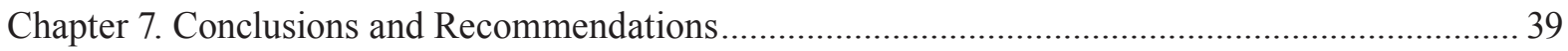

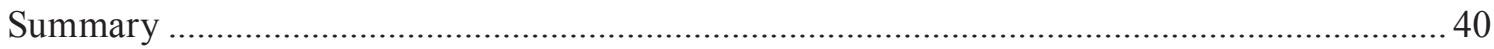

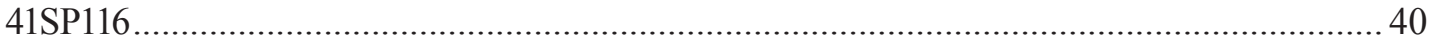

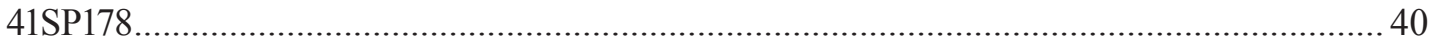

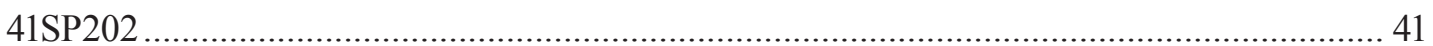

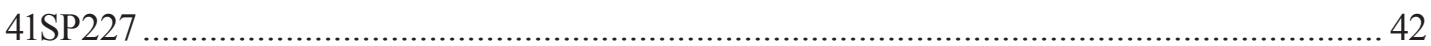

41SP228

41SP234

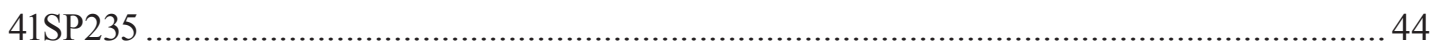

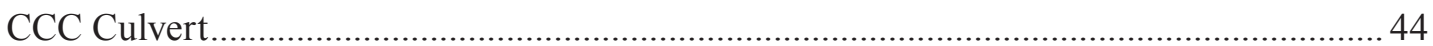

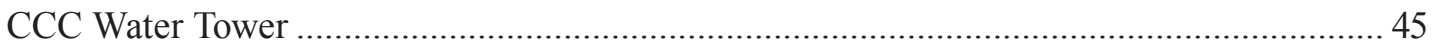

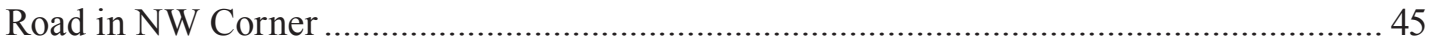

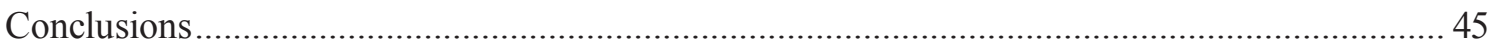

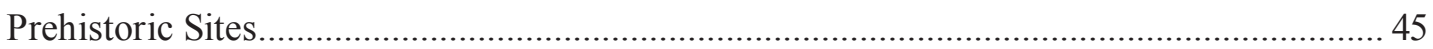

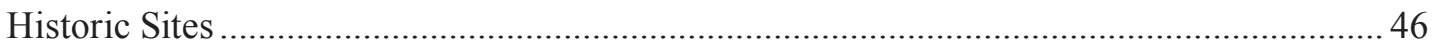

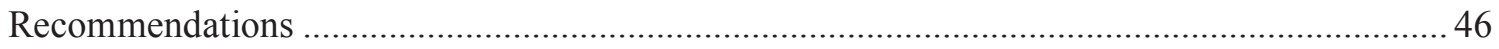

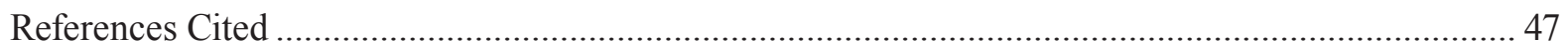

Appendix A. LCCSP Archaeological Survey Shovel Test Resulta ................................................ 51

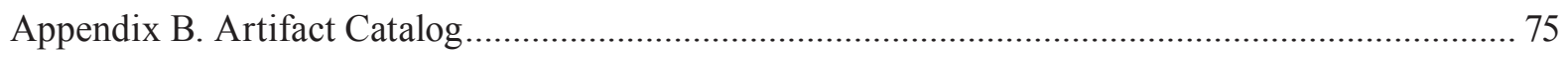

Appendix C. State of Texas Archeological Site Data Forms (Restricted Access Only)..................... 83

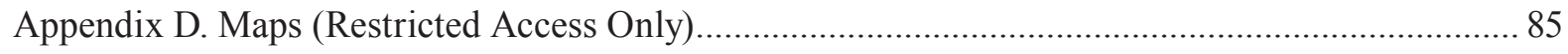

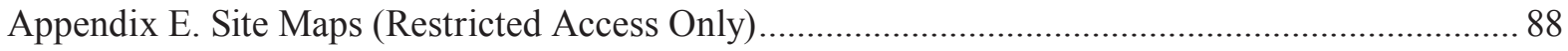




\section{List of Figures}

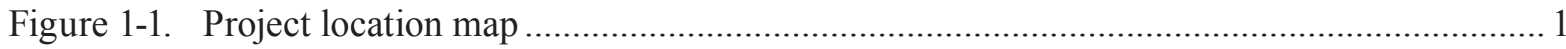

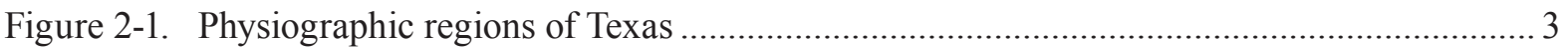

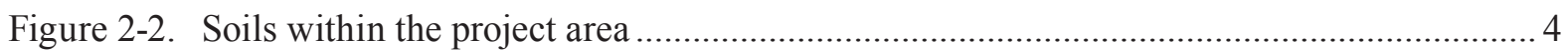

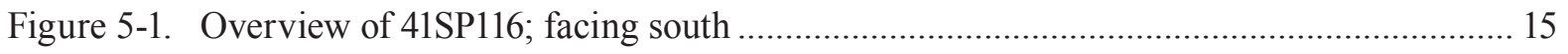

Figure 5-2. Utility pole on peninsula within $41 \mathrm{SP} 116$ site boundary; facing west .......................... 16

Figure 5-3. BBQ grill located within site 41SP116 boundaries; facing southeast............................. 16

Figure 5-4. Concrete slab with chain in center; facing northeast .................................................. 16

Figure 5-5. Water heater located within site 41SP116 boundaries; facing west ................................ 17

Figure 5-6. Windmill water pump located within site 41SP116 boundaries; facing northwest .......... 18

Figure 5-7. Close-up of water pump, displaying patents .............................................................. 18

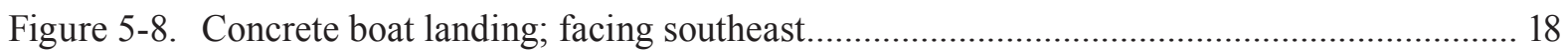

Figure 5-9. Remains of wooden boat pier; facing southeast ........................................................ 19

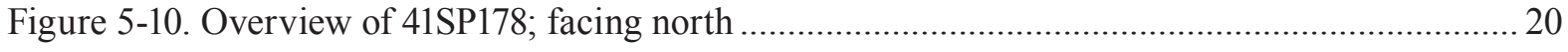

Figure 5-11. Cement block located near 41SP178 foundation feature; facing north ........................... 20

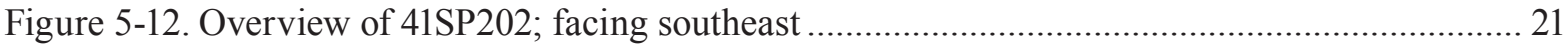

Figure 5-13. Lithic tool (Scraper A) from surface of ST 124, 41SP202; ventral side shown

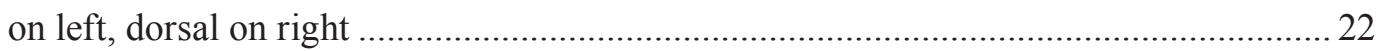

Figure 5-14. Lithic tool (Utilized Flake B) from surface of ST 124, 41SP202; ventral side shown on left, dorsal on right

Figure 5-15. Lithic tool (Scraper C) from surface of ST 124, 41SP202; ventral side shown on left, dorsal on right

Figure 5-16. Lithic tool (Scraper D) from surface of ST 124, 41SP202; ventral side shown on left, dorsal on right 23

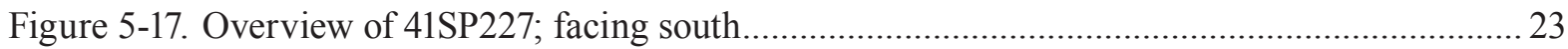

Figure 5-18. Possible bedrock grinding mortars; facing north .......................................................... 24

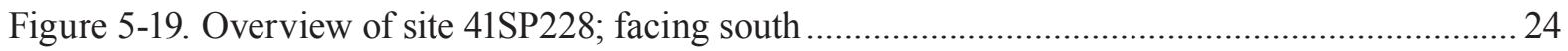

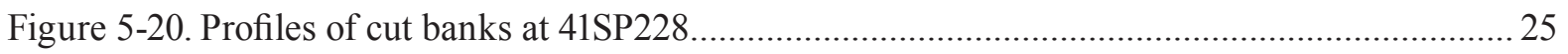

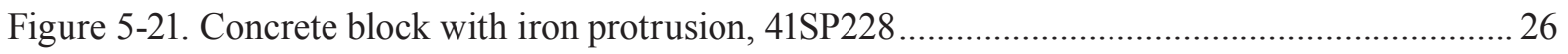

Figure 5-22. Lithic tool (Scraper) from surface of 41SP228; ventral side shown on left,

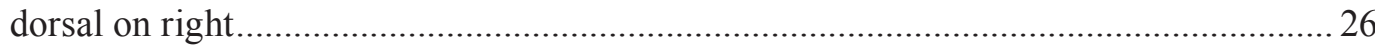

Figure 5-23. Overview of 41SP235; facing west ............................................................................. 27

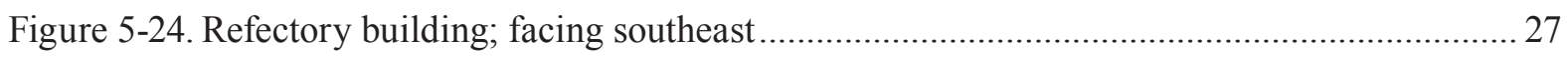


Figure 5-25. Stairwell southwest of refectory building; facing southeast ....................................... 28

Figure 5-26. Pump house scenic overlook; facing northwest ........................................................... 28

Figure 5-27. Exterior of north side of culvert; facing southwest .................................................... 29

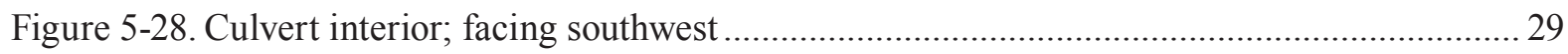

Figure 5-29. Exterior of south side of culvert; facing northeast ....................................................... 29

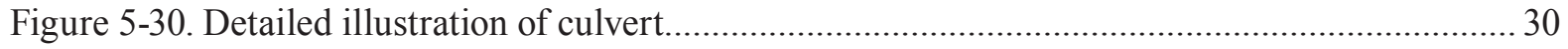

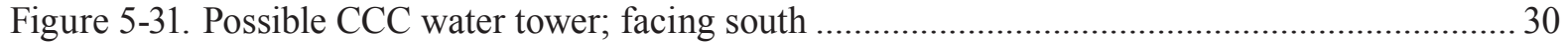

Figure 5-32. Pump house associated with water tower; facing northwest....................................... 31

Figure 5-33. Stock pile of BBQ grills; facing northwest ................................................................ 31

Figure 5-34. Chert stone road base pile; facing northeast................................................................. 32

Figure 6-1. Amber atomizer bottle recovered from ST 75, 41SP228 …........................................ 34

Figure 6-2. Clear art deco bottle recovered from surface, 41SP234 ............................................. 34 


\section{List OF TABLES}

Table 7-1. Site Assessment and Recommendations ....

39 


\section{ACKnOWledgments}

The author would like to thank Texas Parks and Wildlife Department, especially David Aviles, Kent Hicks, Aina Dodge, and Michael Strutt. I would also like to extend a thank you to the field crew, Julian A. Sitters, Jacob Hooge, Sarah Scogin, and Robert Z. Seldon for their timely and expert work in what were often very trying conditions; your hard work is greatly appreciated! Thanks also go to the many individuals involved in the analysis and production of this report. David Yelacic and Eric Wettengel assembled and administered the GIS database. Julian A. Sitters, David Yelacic, and Eric Wettengel also created the illustrations provided in this report. Antonio Padilla assisted in the analysis of collected artifacts. Artifacts and records generated during the investigations were processed by Veronica Suarez and Eulalia M. Cholak for final curation at the Texas Parks and Wildlife Department's Archaeological Laboratory. Maggie McClain edited and assembled this report. This project would not have been possible without the help of these individuals, for which I am truly thankful. 


\section{Chapter 1}

\section{INTRODUCTION}

Lake Corpus Christi State Park is located on the southeastern shore of Lake Corpus Christi, approximately one mile north of the Seale Dam (Figure 1-1). The park is located on Park Road 25, four miles southwest of Mathis off State Highway 359 , and 35 miles northwest of Corpus Christi, Texas. The park consists of 418 acres, 368 acres of which are under lease to the Texas Parks and Wildlife Department (TPWD) by the City of Corpus Christi. This lease agreement was negotiated in 1934 prior to the construction of the park by the Civilian Conservation Corps (CCC), and will expire in 2032. An additional 50 acres located in the northern portion of the park was acquired in 2002 and is owned by TPWD.

TPWD contracted with the Center for Archaeological Studies (CAS) at Texas State University-San Marcos to conduct a cultural resources inventory of archaeological sites within the park. The purpose of the inventory was to identify and evaluate new prehistoric and historic sites and reassess all previously recorded

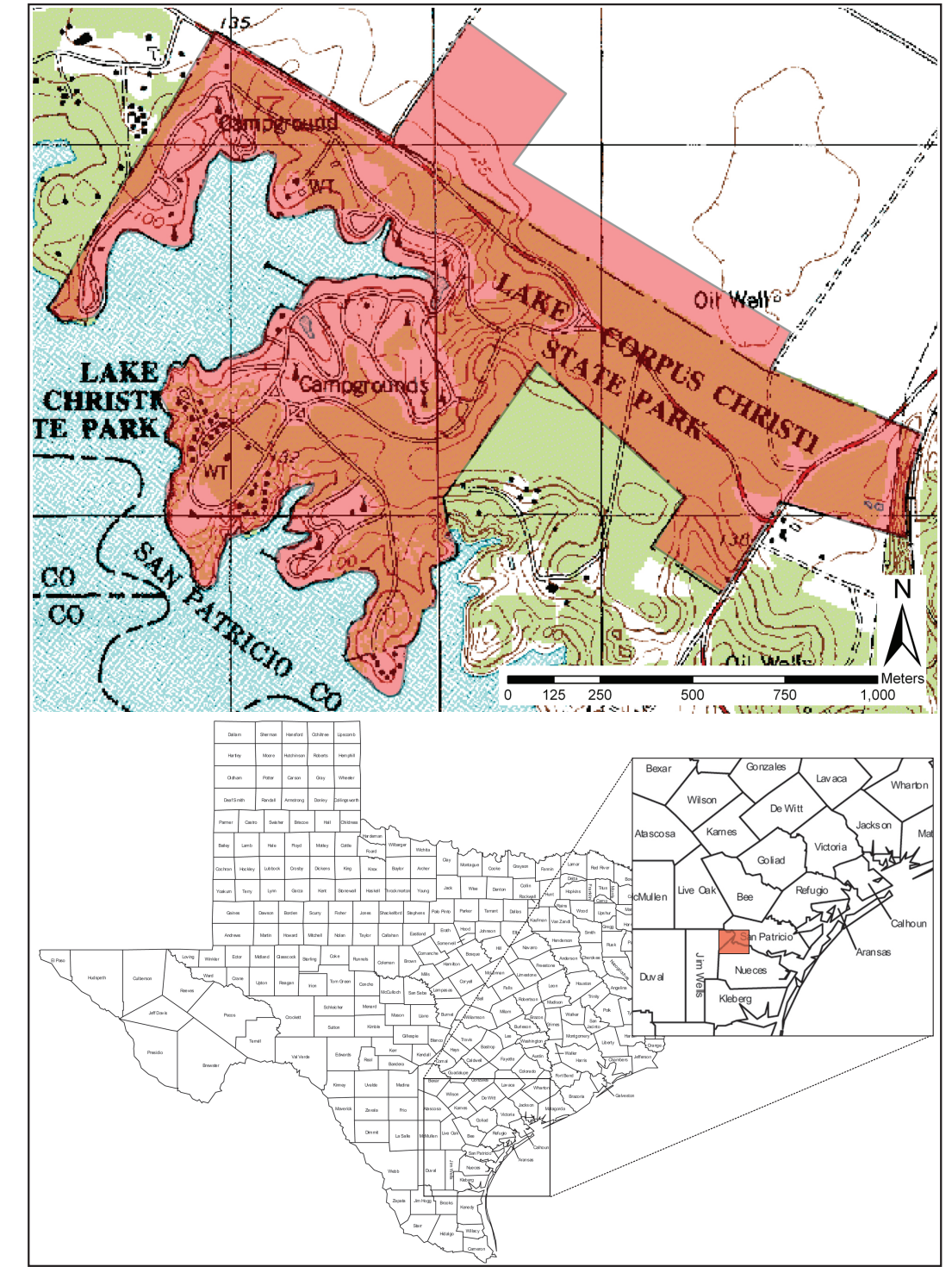

Figure 1-1. Project location map. 
sites. Results from the survey will be used to determine State Archeological Landmark (SAL) and National Register of Historic Places (NRHP) eligibility status of any cultural resources. Resulting data will also be used by TPWD to address long-term stewardship and management of the resources, and to augment a detailed cultural resources management plan for Lake Corpus Christi State Park. All project documents and artifacts collected are curated at TPWD. 


\section{Chapter 2}

\section{Environmental BaCkground}

Lake Corpus Christi State Park is located in the eastern extremity of the South Texas Brush Country, not far from the western border of the Gulf Coast Prairie and Marsh Zone (Figure 2-1). Two geologic-edaphic habitat types occur within the park. These are sugarberry-mesquite woodland located above alluvial deposits, and a mixed-brush shrub land on soils covering limestone outcrops (Ralph 1997).

\section{Vegetation}

The project area lies within the portion of the Southern Coastal Corridor characterized by terrestrial floodplains and adjacent prairies (Mercado-Allinger and Ricklis 1996). Prominent vegetation includes live oak, blackjack oak, hackberry, pecan, mesquite, and a variety of grasses (Jones 1982). Medium to tall grasses, forbs, mesquite and acacia are supported by the clayey soils of the inland prairie, and characterize the majority of the project area. Sandier soils in the northern portion of the project area support live oaks, medium to tall grasses, mesquite, acacia, and spiny hackberry understory communities. Natural vegetation of the region is quickly succumbing to land clearing and cultivation throughout the Southern
Coastal Corridor, including portions of the project area.

\section{Soils}

As described by the US Department of Agriculture Natural Resources Conservation Service (2009), soils within Lake Corpus Christi State Park include: Comitas loamy fine sand (Cs); Delfina loamy fine sand (Dn); Papalote fine sandy loam, 0-1 percent slopes (PaA); Papalote fine sandy loam, 1-3 percent slopes ( $\mathrm{PaB})$; Pettus loam, 0-3 percent slopes (PeB); Pharr fine sandy loam, 1-5 percent slopes (PfC); Raymondville clay loam, 0-1 percent slopes (RaA); Raymondville clay loam, 1-3 percent slopes $(\mathrm{RaB})$; Orelia fine sandy loam (Or); Orelia sandy

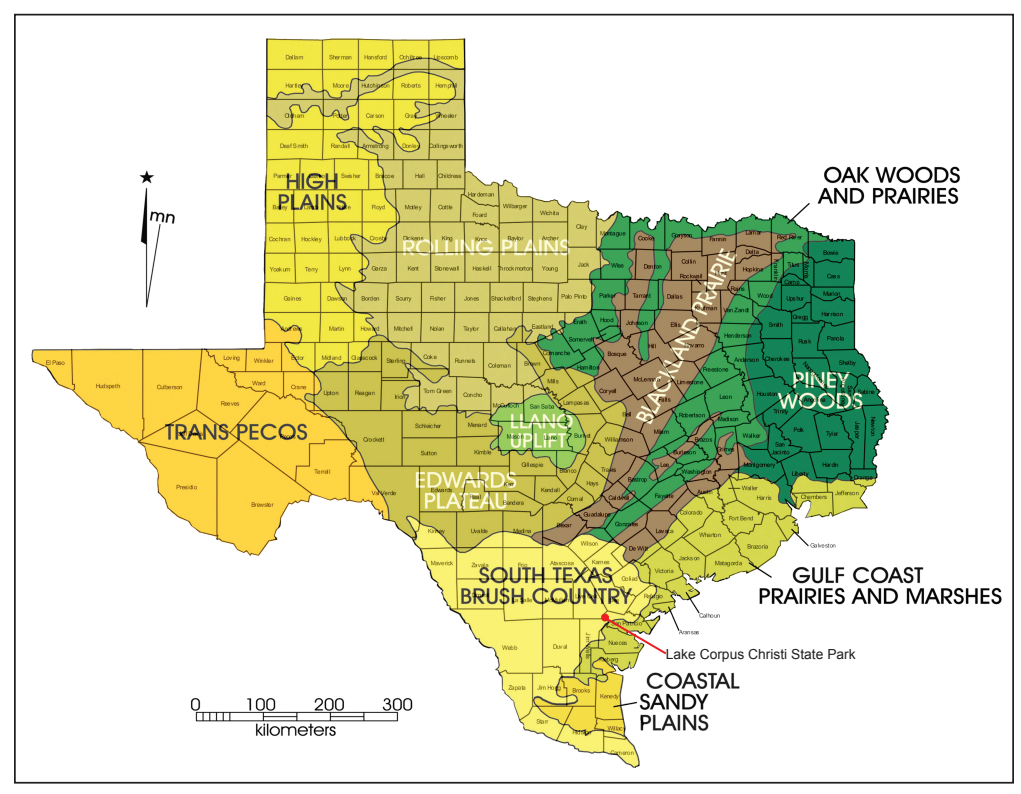

Figure 2-1. Physiographic regions of Texas. 
clay loam (Os); Victoria clay, $0-1$ percent slopes (VcA); Willacy fine sandy loam, 0-1 percent slopes (WfA); and Willacy fine sandy loam 1-3 percent slopes (WfB; Figure 2-2). Generally, soil formation and subsequent taxonomic classification/differentiation depends upon climate, organisms, topography, parent material, and time. Topography, parent material, and time are the most influential factors for differentiation among the variety of soils present in the park. Parent materials of these soils are characteristic of a terrestrial-marine water interface, or in other words, the mouth of the Nueces River and a fluctuating sea level. Ages of the deposits may indicate the type and nature of the archaeological deposits potentially contained therein. The mode of deposition, alluvial versus fluviomarine, will differentially preserve archaeological deposits.

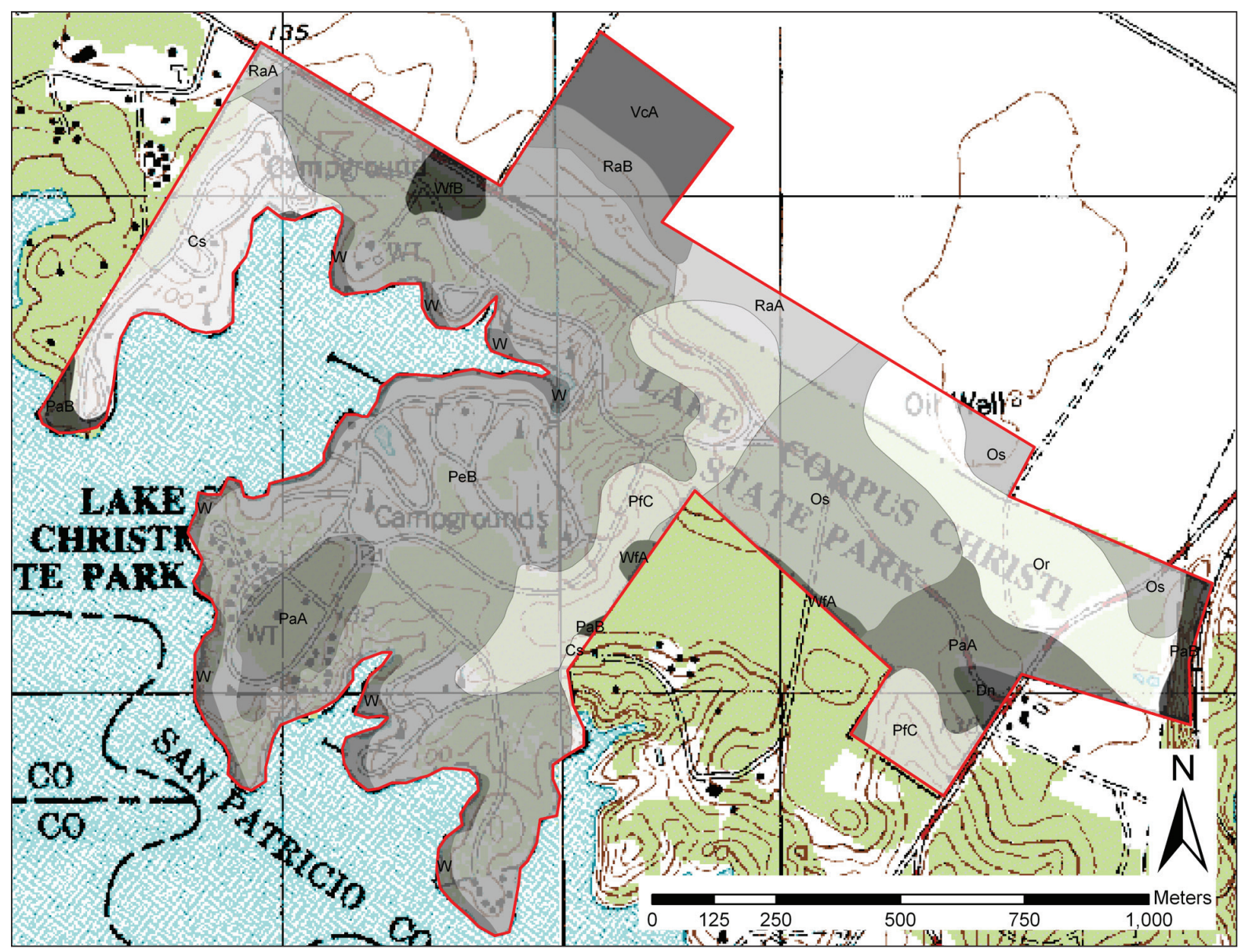

Figure 2-2. Soils within the project area. 


\section{Chapter 3}

\section{MethodS}

A cultural resources survey of Lake Corpus Christi State Park was conducted by archaeologists from CAS between June 7 and June 18, 2010, following guidelines established by the Texas Historical Commission (THC), the Council of Texas Archeologists (CTA), and TPWD. Approximately 368 acres of park land were subject to pedestrian survey and excavation of shovel tests to identify previously unknown cultural resources. Previously identified sites within the park were reassessed and their records were updated accordingly. Locations of possible CCC structures were also investigated.

\section{Field Methods}

In all, 128 shovel test were excavated within the 368 -acre project area, exceeding minimum survey standards established by the THC and CTA for project areas less than 200 acres. In 2002, Marianne Marek surveyed a 50-acre portion of park (Marek 2002). The majority of this previously investigated land was omitted from the current investigation, as there is a low probability of identifying any unknown cultural resources within this area. However, archaeological site 41SP202, which was identified during Marek's survey, was revisited and reassessed.

Pedestrian survey transects were placed and walked approximately 30 meters (m) apart. Shovel test excavations were concentrated in undisturbed, uncleared, and/or unmodified areas. For areas that were disturbed by modern construction and/or clearing, a cursory visual surface inspection was conducted. With the exception of revisited sites and identified possible CCC structure locations, shovel tests were not excavated in disturbed areas.

Shovel tests were excavated in $20-\mathrm{cm}$ levels to $40-60 \mathrm{~cm}$ below surface (cmbs), upon which sterile soils were encountered. Soils were screened through a $1 / 4$-inch mesh, and all cultural materials were collected. Soil descriptions and recovered materials were noted on standardized shovel test forms. All shovel test locations were recorded with a handheld Global Positioning System (GPS) unit with sub-meter accuracy. Temporally diagnostic artifacts encountered on the surface during pedestrian survey were collected and their locations were also recorded with a handheld GPS unit.

Digital photography was used to document all sites, including two general overviews of the site illustrating the site setting (terrain, vegetation, etc.). A photographic log was maintained and completed in the field. Texas Archeological Site Data Forms were completed for all revisited and newly encountered archaeological sites.

\section{Site Evaluations}

Each site discovered or revisited during the survey was evaluated for eligibility for SAL designation with reference to the criteria in Sections 26.7 and 26.8 of the Rules of Practice and Procedure for the Antiquities Code of Texas. If possible, they were also assessed for potential 
eligibility for nomination to NRHP following the National Register Criteria for Evaluation (36CFR 60). Additionally, each prehistoric and/or historic archaeological site discovered or reassessed during the inventory survey was evaluated with regard to specific TPWD management priorities and recommendations for TPWD management practices. Resulting data will be used by TPWD to address long-term stewardship and management of the resources and to augment a detailed resource management plan for Lake Corpus Christi State Park.

\section{Evaluation Criteria}

There are two main cultural properties categories, historic structures and archaeological sites, that are utilized in the evaluation of sites for SAL designations. The evaluation criteria are found in Chapter 26 Rules and Procedures for administering the Antiquities Code of Texas.

Historic structures may be designated as SALs following the criteria in Section 26.7, Criteria for Evaluating Historic Structures, provided that the following conditions are met:

(1) the structure, or building is listed in the National Register of Historic Places; and

(2) the structure, or building fits within at least one of the following criteria:

(A) is associated with events that have made a significant contribution to the broad patterns of our history;

(B) is associated with the lives of persons significant in our past;

(C) is important to a particular cultural or ethnic group;

(D) is the work of a significant architect, master builder, or craftsman;
(E) embodies the distinctive characteristics of a type, period, or method of construction, possesses high aesthetic value, or represents a significant and distinguishable entity whose components may lack individual distinctions;

(F) has yielded or may be likely to yield information important to the understanding of Texas culture or history.

The THC uses Section 26.8, Criteria for Evaluating Archeological Sites, when assessing the appropriateness of official landmark designation, and/or the need for further investigations under the permit process:

(1) the site has the potential to contribute to a better understanding of the prehistory and/or history of Texas by the addition of new and important information;

(2) the site's archaeological deposits and the artifacts within the site are preserved and intact, thereby supporting the research potential or preservation interests of the site;

(3) the site possesses unique or rare attributes concerning Texas prehistory and/or history;

(4) the study of the site offers the opportunity to test theories and methods of preservation, thereby contributing to new scientific knowledge;

(5) the high likelihood that vandalism and relic collecting has occurred or could occur, and official landmark designation is needed to insure maximum legal protection, or alternatively further investigations are needed to mitigate the 
effects of vandalism and relic collecting when the site cannot be protected.

Properties listed or potentially eligible for listing on the NRHP fall under the jurisdiction of Section 106 of the National Historic Preservation Act of 1966. The criteria for nominating properties and determining NRHP eligibility is contained in 36CFR60 (United States Congress 2004). The NRHP evaluation criteria attempt to address the historical significance of a wide variety of properties, both historical and archaeological, including places, structures, and objects as stated in 36CFR60.4:

The quality of significance in American history, architecture, archeology, engineering, and culture is present in districts, sites, buildings, structures, and objects that possess integrity of location, design, setting, materials, workmanship, feeling, and association and

(a) that are associated with events that have made a significant contribution to the broad patterns of our history; or

(b) that are associated with the lives of persons significant in our past; or

(c) that embody the distinctive characteristics of a type, period, or method of construction, or that represent the work of a master, or that possess high artistic values, or that represent a significant and distinguishable entity whose components may lack individual distinction; or

(d) that have yielded, or may be likely to yield, information important in prehistory or history.

Buildings and structures generally have to be at least 50 years old and in their original context, location, and condition to be considered eligible. Properties are nominated to the NRHP by the State Historic Preservation Officer in consultation with the National Park Service.

\section{Assessment of Site Management Priority}

Each prehistoric and/or historic archaeological site discovered or reassessed during the inventory survey was evaluated with regard to specific management priorities and recommendations for management practices. Each site's research potential and suitability for designation as an SAL and/or nomination to the NRHP lead directly to its management priority ranking, while each site's susceptibility to natural and cultural impacts were used to recommend particular management practices. Sites that are designated as SALs are ranked as Management Priority 1 , and sites that are recommended for official designation as SALs and/or recommended as eligible for listing on the NRHP are ranked as Management Priority 2, in order to focus efforts on preventing impacts on these sites. Sites whose SAL status and eligibility for listing on the NRHP are undetermined are ranked at Management Priority 3, so that additional efforts (i.e., further archaeological investigations) may be directed at them. Sites that have been determined to be ineligible for SAL status and/or recommended as not eligible for listing on the NRHP are ranked at Management Priority 4, and have the lowest priority for management and protection.

\section{Laboratory Procedures and Curation Preparation}

A temporary field laboratory was established at the project location and artifacts and forms were accounted for on a daily basis. At the completion of fieldwork, all collected cultural materials and field forms were transported to the CAS lab in San Marcos for processing and inventory. All recovered artifacts were processed in accordance 
with the TPWD Archeology Lab Manual, and analysis was conducted during processing. All collected cultural materials were prepared for curation in accordance with federal regulation 36 CFR 79, current guidelines of the CTA, TPWD Archeology Lab Manual, and with Texas Archeological Research Laboratory (TARL) guidelines. Processed artifacts were stored in archival-quality bags and acid-free labels were placed in all bags. Artifacts were individually labeled and coated with PVA when appropriate. Processed materials were then stored in acid-free boxes with standard labels. 


\section{Chapter 4}

\section{Previous Investigations ANd Cultural History}

\section{Previous Investigations}

Five archaeological sites within the boundaries of Lake Corpus Christi State Park were identified during previous investigations (Figure D-1, Appendix D). These previously recorded sites include 41SP116, 41SP178, 41SP202, 41SP227, and 41SP228. In addition, Quimby McCoy Preservation Architecture, LLP, conducted an inventory and assessment of the CCC structures located within Lake Corpus Christi State Park and prepared a report in September of 2008.

\section{SP116}

In October of 1982, the Center for Archaeological Research at The University of Texas at San Antonio conducted a pedestrian survey of a proposed well pad site within Lake Corpus Christi State Park (Lukowski 1984). The project location was described to be positioned on a ridge that extended out into Lake Corpus Christi, slightly north of the Wesley Seale Dam. According to Lukowski, the area was cleared of mesquite and prickly pear and extensively modified to serve as a fishing resort camp. Three standing structures or cabins were noted, in addition to concrete foundations that marked the locations of recent structures. Noted nonnative vegetations included mulberry bushes, palms, and grasses. A light lithic scatter was documented on the surface over the ridge containing the proposed well pad site. Two shovel tests were excavated during the 1982 survey, which recovered both modern/historic debris and prehistoric lithic debris. While the presence of a light lithic scatter suggested that the area was once the locus of prehistoric activity, the extensive land modifications and the mixing of prehistoric and modern/historic debris led to the conclusion that no further investigations were warranted at the site. $41 \mathrm{SP} 116$ was recommended as not eligible for SAL or NRHP listing.

A subsequent cultural resources survey of four water well drilling sites within the park by James E. Warren (1984) reassessed 41SP116. The proposed location of Well Pad No. 2 was surveyed in October of 1984 just to the north of the 41SP116 site boundary. Survey consisted of pedestrian survey and the excavation of "random shovel tests" (Warren 1984). No evidence of previous occupations was noted by either surface inspection or shovel test excavation at the proposed location of Well Pad No. 2. However, due to the dense nature of the vegetation in the proposed location and the proximity of 41SP116, monitoring of construction activities at this location was recommend (Warren 1984).

In January of 1985, TPWD archaeologist Ron Ralph conducted additional investigations at 41SP116. Ralph (1997) concluded that the historic component at 41SP116 was too recent to be a by-product of the CCC and that it postdated WWII. According to Ralph, the area was an old park dump. Ralph stated that the area had been bulldozed pushed and burned repeatedly in the 
past. However, a triangular Tortugas projectile point was recovered from site during Ralph's visit. It was recommended that the area be seeded with rye grass to retard erosion (Ralph 1997).

\section{$41 S P 178$}

A historic foundation, 41SP178, was discovered in November of 1991 by TPWD archaeologists monitoring utility line repairs in the Utility Camping Loop area (Boes 1991). The concrete foundation was located in a small growth of scrub $30 \mathrm{~m}$ south-southwest of Campsite No. 5. An inspection of the surrounding ground surface uncovered brick, glass, and historic ceramic debris. Four shovel tests were excavated around the sides of the structure. These shovel tests yielded historic debris consisting of brick, glass, nails, mortar, and ceramics. TPWD archaeologists concluded that this was a historic site, and the location was registered with TARL.

A State of Texas Archeological Site Data Form was submitted to TARL in November of 1991 naming the site the "Farm House Site" (Boes 1991). According to the form, the structure appeared to have been destroyed by fire prior to the construction of the camping area and subsequently covered with dirt, leveling its surface with the surrounding hillside, and ultimately resulting in the protrusion of the northern portion from the surrounding ground surface. The form states that "a 1920s farm is said to have been here but the whereabouts of those structures has since been forgotten" (Boes 1991). The site was recommended for preservation via avoidance (Boes 1991).

\section{SP202}

An archaeological survey of the 50-acre addition to Lake Corpus Christi State Park was conducted by Marek (2002). Cultural remains were identified in two areas of the parcel. A modern well constructed with PVC pipe was identified and believed to be associated with former irrigation of the area. Due to its recent origin, it was not classified as an archaeological site. A lithic scatter of unknown age, designated 41SP202, was also identified. Marek states that only a portion of this site is located within the 50-acre parcel; the boundaries of the site extend to the south into a wooded section of park property. Artifacts encountered during the survey of this area were generally located on the surface and were noted as widely dispersed by plowing (Marek 2002). While the portion located within the 50-acre parcel was determined to be ineligible for SAL or NRHP listing, the portion extending southward was not evaluated. Marek recommended avoidance of the site until the entire site can be evaluated (Marek 2002).

\section{SP227}

Archaeological site 41SP227 was identified during an archaeological survey by TPWD archaeologist Chris Ringstaff in 2007 (Ringstaff 2007a). 41SP227 was described as a Late Archaic lithic procurement site and possible open campsite. The site is located atop a gravelcapped point immediately south and west of the park's Depression-era CCC pavilion. Ringstaff noted that the site is located approximately $150 \mathrm{~m}$ east of the river channel, and its location would have afforded a considerable view of the Nueces River Valley. An Ensor point was recovered during investigations, suggesting a Late Archaic occupation. Additional recovered artifacts included lithic debitage, biface fragments, and tested cobbles. Ringstaff concluded that based on the recovery of siliceous gravels, tested cobbles, and debitage, the site appears to have been primarily utilized as a lithic procurement site. As the majority of the site lies within dense brush, additional investigations of the area would be needed to determine any additional function. The 
northern portion of the site was impacted by the construction of the CCC Refectory Building in 1935, and the site continues to be heavily impacted by a pedestrian trail that bisects it. Ringstaff recommended additional investigation of this site to determine its research value (Ringstaff 2007a).

\section{$41 S P 228$}

41SP228 consists of a scatter of historicera artifacts and a prehistoric lithic scatter/ open campsite recorded by TPWD archaeologist Chris Ringstaff in 2007 (Ringstaff 2007b). This site is located in a cleared field within the south camping loop, approximately $170 \mathrm{~m}$ northeast of a fishing pier. Investigation of this location included pedestrian survey and shovel test excavation. The prehistoric component of the site dated to the Archaic based on the recovery of a Martindale-like dart point. Additional recovered artifacts included lithic debitage, solarized glass, whiteware, chert cores, biface fragments, and mussel shell fragments. An area of dense lithic debitage was noted by Ringstaff in the southern portion of the site and may represent a lithic reduction feature or overlapping features (Ringstaff 2007b). Ringstaff recommended limited trench investigations in this area due to the presence of sandy deposits, which suggest the possibility of intact buried features or materials. In addition, he recommended further exploration of the wooded section in the western portion of the site (Ringstaff 2007b).

\section{Inventoried/Assessed Civilian Conservation Corps Structures}

Fourteen CCC structures and/or features were inventoried and assessed by Quimby McCoy Preservation Architecture, LLP, in November of 2008 (Quimby McCoy 2008). These structures and/or features included: the Refectory, the concrete Water Tank at the Superintendent's Residence, a Road Remnant near the Park
Superintendent's Residence, two Concrete Benches at the Park Superintendent's Residence, a Stone Pile near the Park Superintendent's Residence, the Park Entrance, the Well House, the Overlook, and six Culverts. The inventory and assessment consisted of a description of each structure/feature, an assessment of its current condition, recommendations, and probable construction cost summary. Photographs, GPS location information, and historic drawings of the CCC features were also presented (Quimby McCoy 2008).

\section{Cultural History}

Previous archaeological research is limited in the area of Lake Corpus Christi, where the three counties of San Patricio, Jim Wells, and Live Oak meet. Therefore, not much is known about the cultural history of the area. The lake itself was constructed prior to state or federal regulations requiring archaeological studies. The project area is located within the Southern Coastal Corridor Archeological Region of Texas (Mercado-Allinger et al. 1996). The cultural chronology of this region includes the following periods: Paleoindian (9200-6000 BC), Archaic (6000 BC-AD 800), Late Prehistoric (AD 8001600), and Historic (AD 1600-1940).

\section{Paleoindian}

Sites dating to the Paleoindian period (9200-6000 BC) are uncommon in the area, but limited numbers of Clovis, Folsom, Plainview, Golondrina, Scottsbluff, and Angostura projectile points have been identified (Hester 1975). Occupations of the region during this time are characterized as low population density and small-sized bands with extremely large territorial ranges (Black 1989). What few Paleoindian sites that have been identified are located in the uplands or on high terraces. 


\section{Archaic}

The Archaic period is divided into the Early Archaic (6000-2500 BC), Middle Archaic (2500-400 BC), and Late Archaic (400 BC-AD 800; Mercado-Allinger et al. 1996). While there appears to be little information on the transition from the Paleoindian period to the Archaic period, evidence gathered from the area indicates a shift in subsistence from big game hunting to exploitation of estuarine resources (MercadoAllinger and Ricklis 1996).

The Early Archaic in this region is characterized by the appearance of shell middens, dart points, large thin triangular bifaces, and beveled tools. Archaeological data suggest that low population density with large territorial ranges continues from the Paleoindian period (Mercado-Allinger et al. 1996). While the majority of cultural deposits dating from this period occur in upland locations, some alluvial and coastal sites have been recorded (Scott and Fox 1981).

The Middle Archaic is characterized by stemmed projectile points, medium-sized triangular bifaces, and beveled tools in addition to ground stone artifacts such as manos, grinding slabs, and tubular stone pipes (Black 1989). Middle Archaic sites are found in a greater range of topographic settings, including along estuary bays, further inland and upland, and alluvial and tributary settings. This change in location may indicate a shift in subsistence that includes more plant resources. Increased populations are suggested in this phase by evidence of large interaction spheres as well as the presence of cemeteries (Mercado-Allinger et al. 1996).

Large, thick, shell midden deposits are characteristic of the Late Archaic and appear to be more common and visible than at Early or Middle Archaic sites. Small corner- or side- notched dart points are common for this period. Late Archaic sites have been found in all settings, including cemeteries along the coastline. Subsistence strategies include the exploitation of shellfish, fish, and small mammals in addition to the continued use of plant resources (MercadoAllinger et al. 1996).

\section{Late Prehistoric}

The Late Prehistoric (AD 800-1600) is characterized by the appearance of pottery and the use of the bow and arrow (Mercado-Allinger and Ricklis 1996). This period is the most well understood in the region. The transition to the Late Prehistoric appears to be rapid, evidenced by a shift to very small, expanding-stemmed projectile points. The Rockport complex begins in the region by AD 1200, and is defined by the presence of Rockport pottery, which is a thin, grey, sandy-paste ware. Other distinctive artifact types and evidence of the Late Prehistoric include beveled knives and small endscrapers, and evidence of long-distance trade. Sites from this period are common along the Texas coast, with the majority of them located within $50 \mathrm{~m}$ of a water source along bays, brackish water streams leading to bays, and barrier islands (Black 1989).

\section{Historic}

Several Spanish and French explorers, including Alonso Álvarez de Pineda, Alonso De León, Jean Béranger, Diego Ortiz Parrilla, and José de Evia, traveled through what is now San Patricio County. Mexican sheepherders also camped in the area before the era of European colonization. Colonization of the county begin in 1828 with empresarios John McMullen and James McGloin, who contracted with the government of Mexico to settle 200 Irish Catholic families on 80 leagues of land. The first groups of families, recruited from the Irish population of New York, landed at El Cópano and Matagorda in late 1829; 
two other groups soon followed. The colonists proceeded to the east side of the Nueces River and established the town of San Patricio de Hibernia, named after the patron saint of Ireland. In 1834, the colony was legally established as the Municipality of San Patricio in the Mexican state of Coahuila and Texas (Guthrie 2010a).

By 1836, 84 land grants had been made in the colony, and about 500 people were living there. The colonists eventually became engulfed in fighting during the early stages of the Texas Revolution. San Patricio County was established by the Congress of the new Republic of Texas following the Texas Revolution in 1836. The original San Patricio County included territory later incorporated into other counties. The area was not really stabilized, however, until General Zachary Taylor moved his army into the region after Texas was annexed by the United States in 1845. By 1850 , cattle ranching was the focus of the local economy, with further changes resulting from the Civil War. While far removed from the main battle lines, the area became a major center of cotton smuggling on the Cotton Road to Matamoros, Mexico, after the Union government imposed a blockade on the South (Guthrie 2010a).

Following the Civil War, ranching continued to dominate the local economy, but crop cultivation also began to take hold. In 1871, Thomas M. Coleman and Colonel George W. Fulton joined with J. M. and Thomas H. Mathis in a partnership that formed the largest cattle firm in Texas: the Coleman, Mathis, and Fulton partnership, which held acreage in San Patricio, Goliad, and Aransas counties. The company flourished until an 18-month drought in 1878-79 wiped out much of its stock. When the partnership was dissolved in 1879, T. H. Mathis, who was awarded 64,000 acres of the firm's land, began plans to develop a town site, Mathis, on his property. The San Antonio, Uvalde, and
Gulf Pacific Railroad reached Mathis in 1913, and a chamber of commerce was organized the same year. Mathis grew as a trading center for a large ranching area reaching into Nueces, Jim Wells, Live Oak, and Bee counties. Ranching and cotton and corn farming were the basis of the city's economy until the early 1930s, when vegetable production began on a large scale. The construction of Lake Corpus Christi on the Nueces River four miles from Mathis opened a new area of development in the early 1930s. (Guthrie 2010b).

The land upon which Lake Corpus Christi State Park is located was leased from the City of Corpus Christi in 1934. The park opened in 1934, and many of the park's facilities were built by the CCC during the 1930s. Buildings constructed included a bathhouse, park residence, and a refectory, but only the refectory remains. This Mediterranean-style building was built from casts of local caliche. The blocks were cast in various sizes and laid in a random-ashlar pattern, closely resembling cut limestone (Steely 1999).

The 21,000-acre lake next to Lake Corpus Christi State Park was formed by damming the Nueces River. A reservoir called Lake Lovenskiold was created in this valley in 1929 by the construction of the La Fruita Dam across the Nueces River. The dam was washed out the same year it was constructed, and rebuilt in 1935 with federal funds provided by President Roosevelt's New Deal. The name was then changed to Lake Corpus Christi. In 1959, the Wesley Seale Dam raised the level of the lake to 94 feet (ft) above sea level and brought more lakeside development. The new dam made Lake Corpus Christi one of the largest artificial bodies of water in Texas. It covers 21,000 acres, with a capacity of 300,000 acre-ft at the spillway elevation of $94 \mathrm{ft}$ above sea level (Texas Parks and Wildlife 2010). 


\section{Chapter 5}

\section{Results of Field Investigations}

CAS archaeologists revisited and reassessed five previously identified archaeological sites (41SP116, 41SP178, 41SP202, 41SP227, and 41SP228). Investigators conducted pedestrian survey and excavated 128 shovel tests in undisturbed areas (Appendix A), and conducted pedestrian survey and visual surface inspection in disturbed areas. Appendix B lists artifacts recovered from the shovel tests. Two new sites were recorded (41SP234 and 41SP235). In addition, three new CCC-era features (a culvert, a water tower, and a road) were identified. State of Texas Archeological Site Data forms, maps, and site maps are presented for restricted access only in Appendices C, D, and E.

\section{Revisited Sites}

\section{$41 S P 116$}

Archaeological site 41 SP116 was originally identified as a light lithic scatter during a survey of a well pad site within Lake Corpus Christi State Park by Lukowski in 1982. The site was recommended as not eligible for SAL status or NRHP listing. The site was reassessed in 1984 by Warren, who described the site as a lithic procurement area and workshop. A prehistoric triangular Tortugas projectile point was identified in the area of 41SP116 by TPWD archeologist Ron Ralph in 1985 (Ralph 1997).
Archaeologists from the CAS revisited archaeological site 41 SP116 during the current investigation (Figure 5-1). The site is located on a peninsula in Lake Corpus Christi State Park that extends into Lake Corpus Christi. The peninsula is characterized by dense vegetation consisting of tall grasses, prickly pear cactus, mesquite, blackbrush, brasil, and other thorny plants, as well as two tall palm trees. Ground surface visibility was less than 10 percent with exposed surfaces consisting of sandy loam deposits. While no standing structures were noted, the remains of a shack or shelter consisting of a large piece of corrugated metal sheet (ca. $5 \times 6$ $\mathrm{ft}$ ) were identified. Its location was recorded with a handheld Trimble GeoExplorer XT GPS unit. In addition, five utility poles (Figure 5-2), two metal barbeque grills (Figure 5-3), four

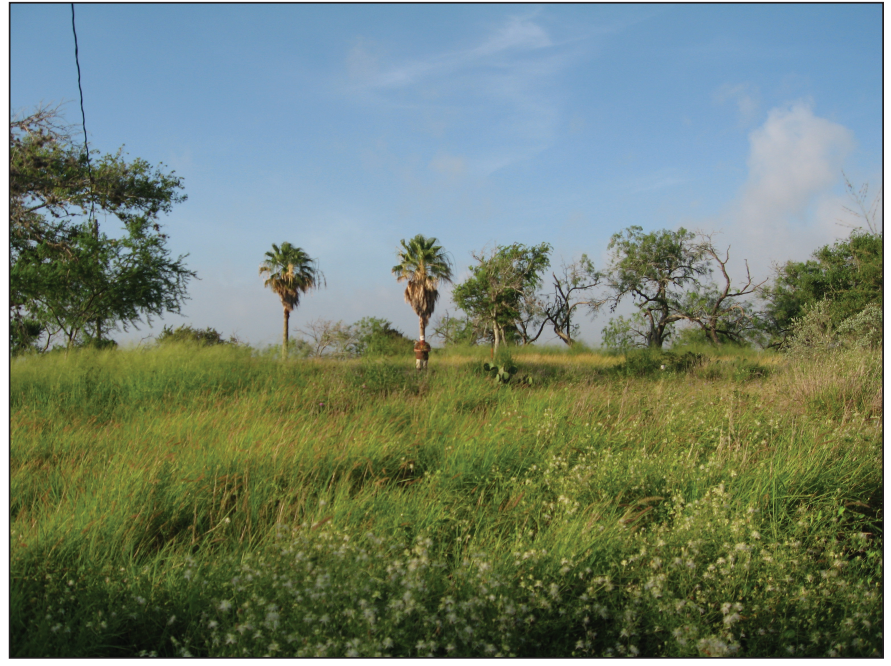

Figure 5-1. Overview of 41SP116; facing south. 


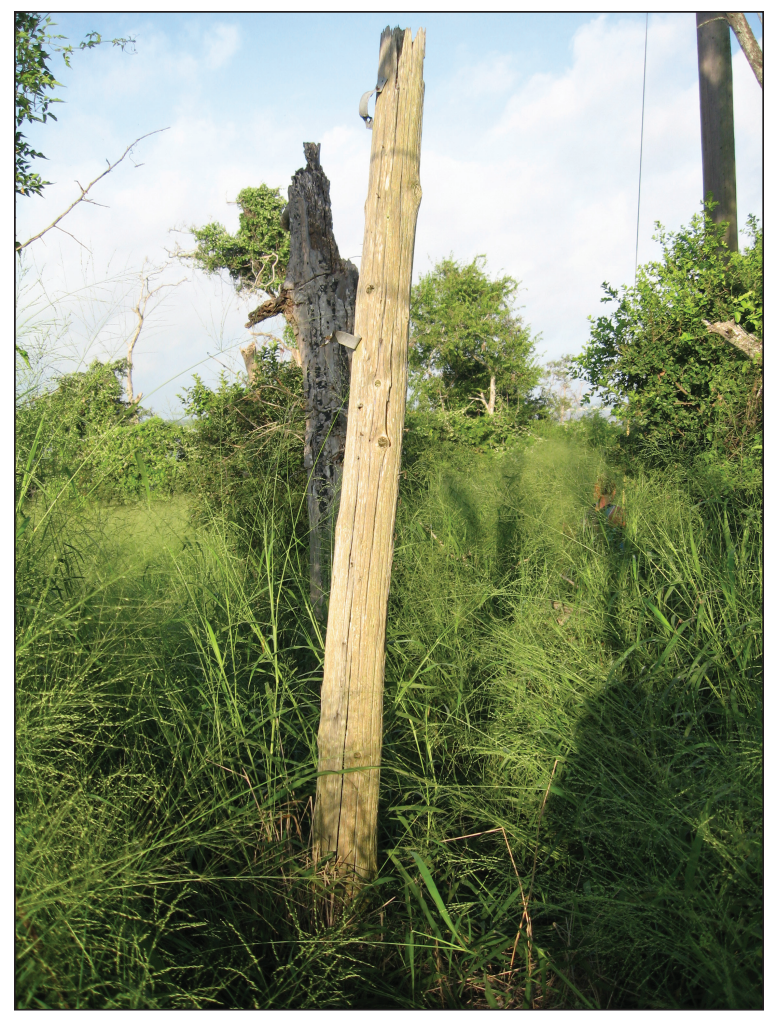

Figure 5-2. Utility pole on peninsula within 41SP116 site boundary; facing west.

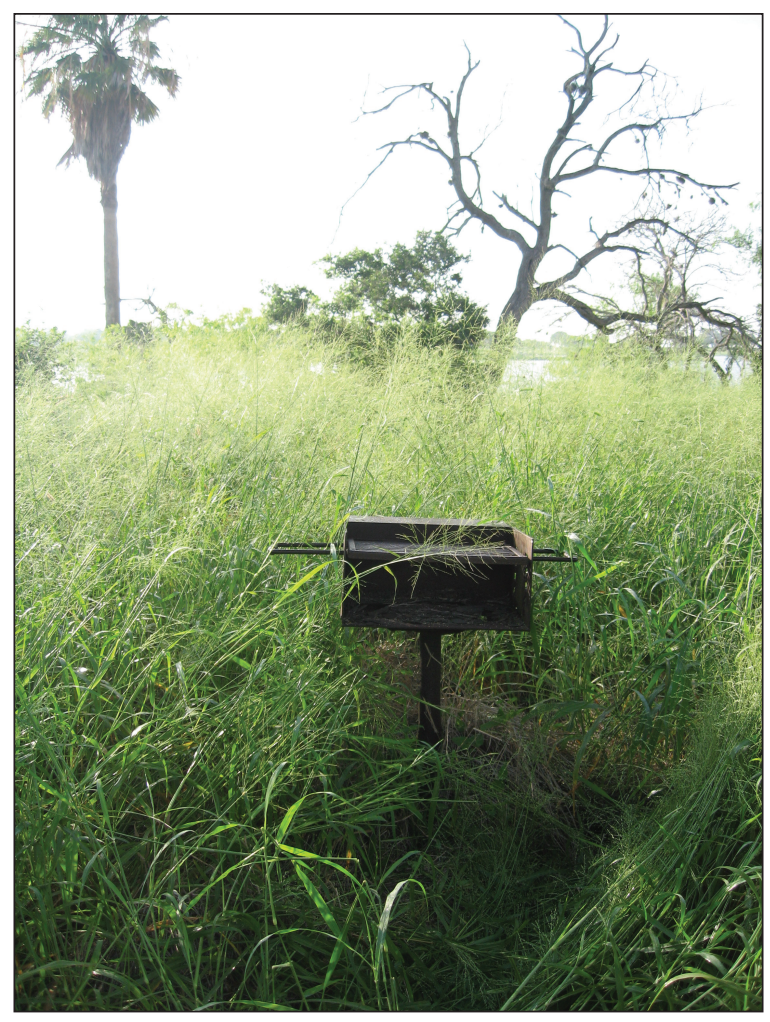

Figure 5-3. BBQ grill located within site 41SP116 boundaries; facing southeast.

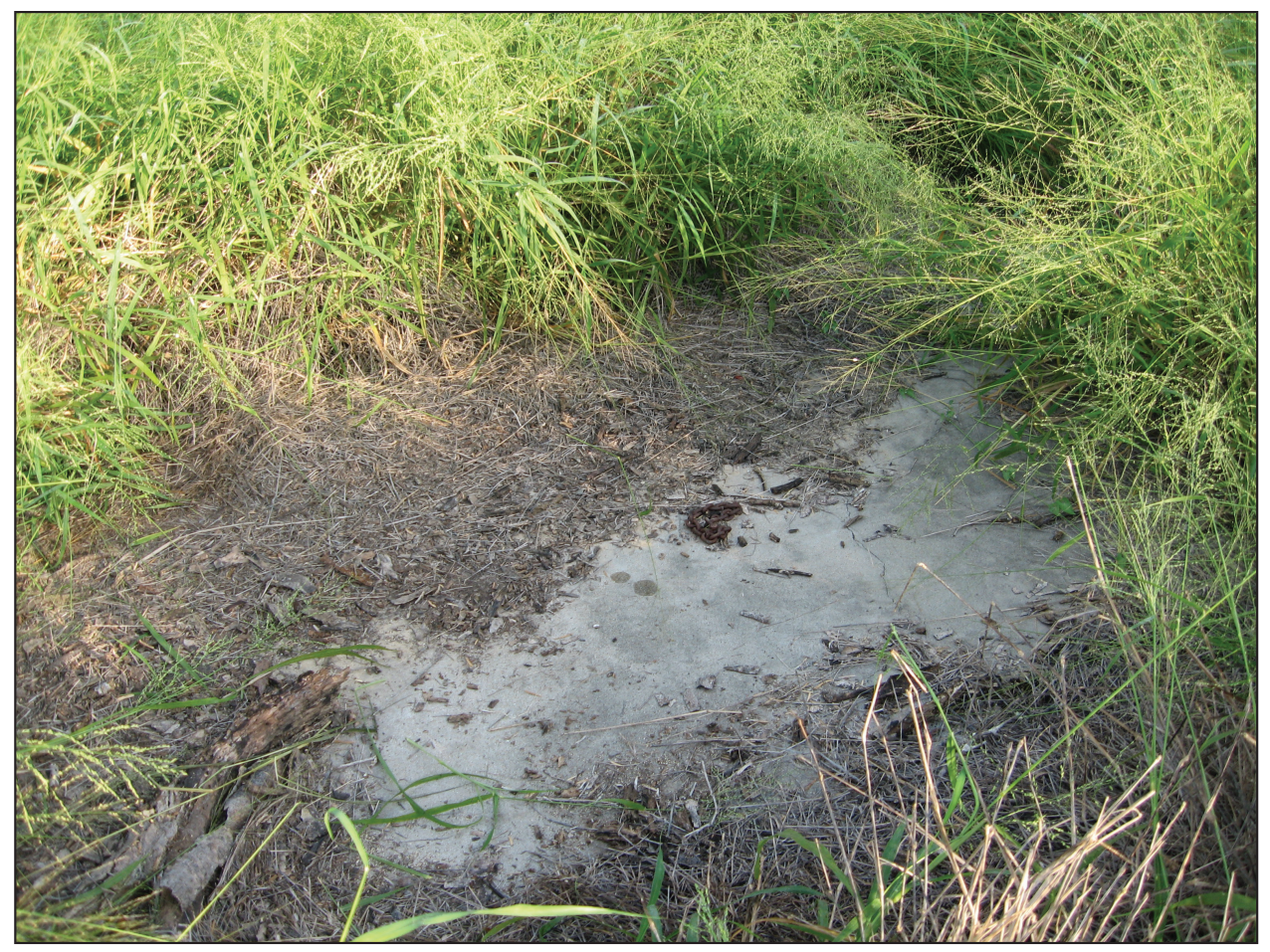

Figure 5-4. Concrete slab with chain in center; facing northeast. 


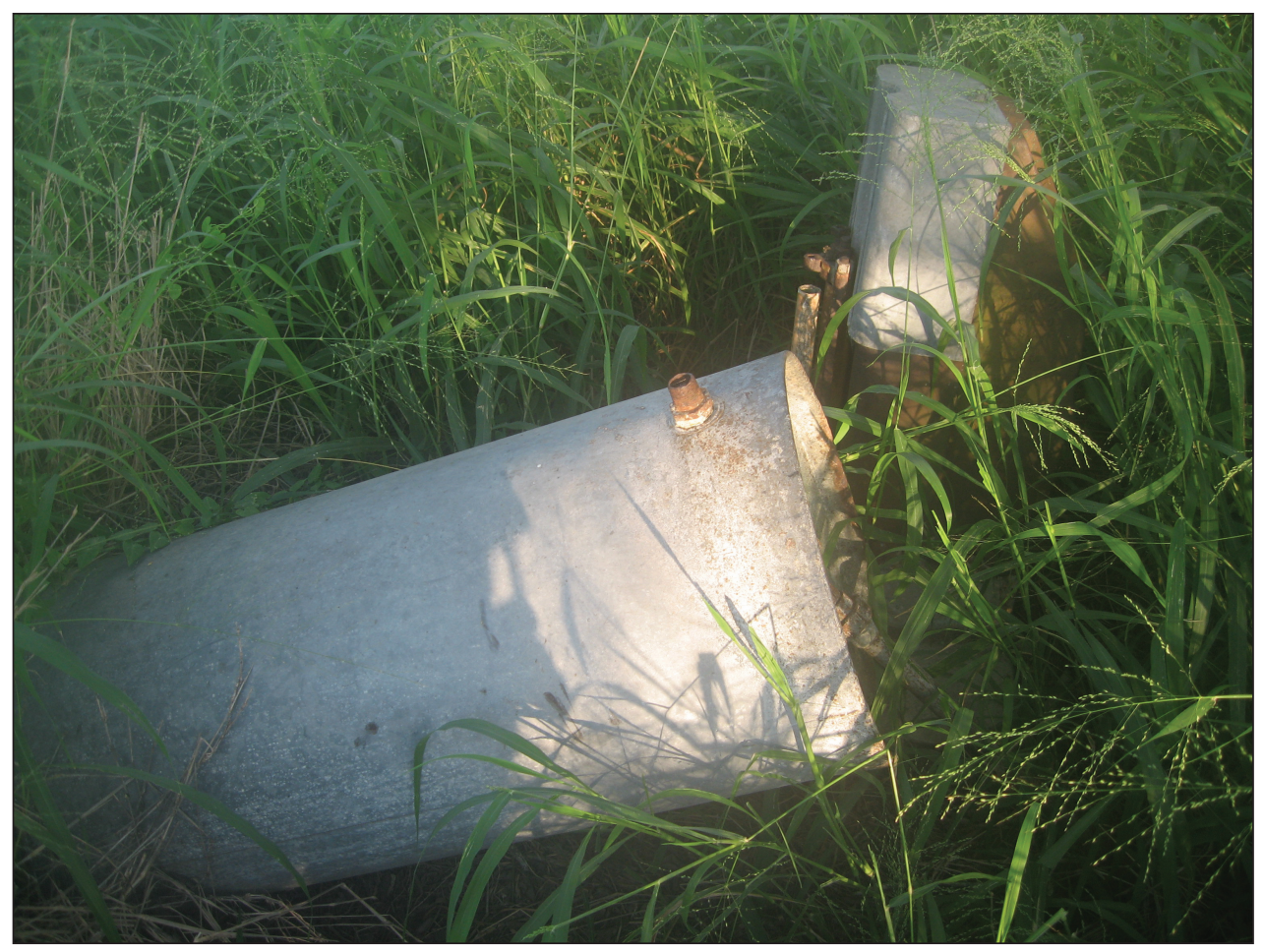

Figure 5-5. Water heater located within site 41SP116 boundaries; facing west.

concrete pads (one with PVC pipes protruding upward; Figure 5-4), one possible water tank (Figure 5-5), a windmill water pump (Figures 5-6 and 5-7), a concrete boat landing (Figure 5-8), and the remains of a wooden boat pier (Figure 5-9) were identified and their locations were recorded. Four shovel tests were excavated within the existing boundaries of 41SP116 (ST 68, ST 69, ST 70, and ST 71). All shovel tests were sterile of any subsurface cultural remains; a single lithic flake was identified on the surface of ST 70. Excavated soils consisted of sandy loams.

To include all the identified surface features, the boundaries of 41SP116 were reassessed and redrawn to encompass the entire southern portion of the peninsula. While the surface features appear to be of a recent nature, the actual age of these deposits are currently unknown and may date to historic times. The identified windmill pump was manufactured by the Aeromotor Company of Chicago and contained a patent number of 1901061 (see Figure 5-7). A review of registered US patents revealed that this was a patent for a pump invented by Daniel R. Scholes registered on March 14, 1933.

\section{SP178}

Archaeological site 41SP178 was recorded by TPWD staff archaeologists in 1991 as the "Farm House Site." This site was characterized by a weathered concrete foundation located along the hill slope area between the shelter area to the south and the utility camping loop at the northern bottom end of the slope. The foundation was visible within a small cluster of trees. Remnants of brick, glass, and historic ceramics were noted on the surface surrounding the feature during initial investigations. Four shovel tests were excavated around the sides of the foundation by TPWD staff archaeologists in November 1991, and all yielded historic debris that included glass, brick, mortar, nails, and ceramics. It was 


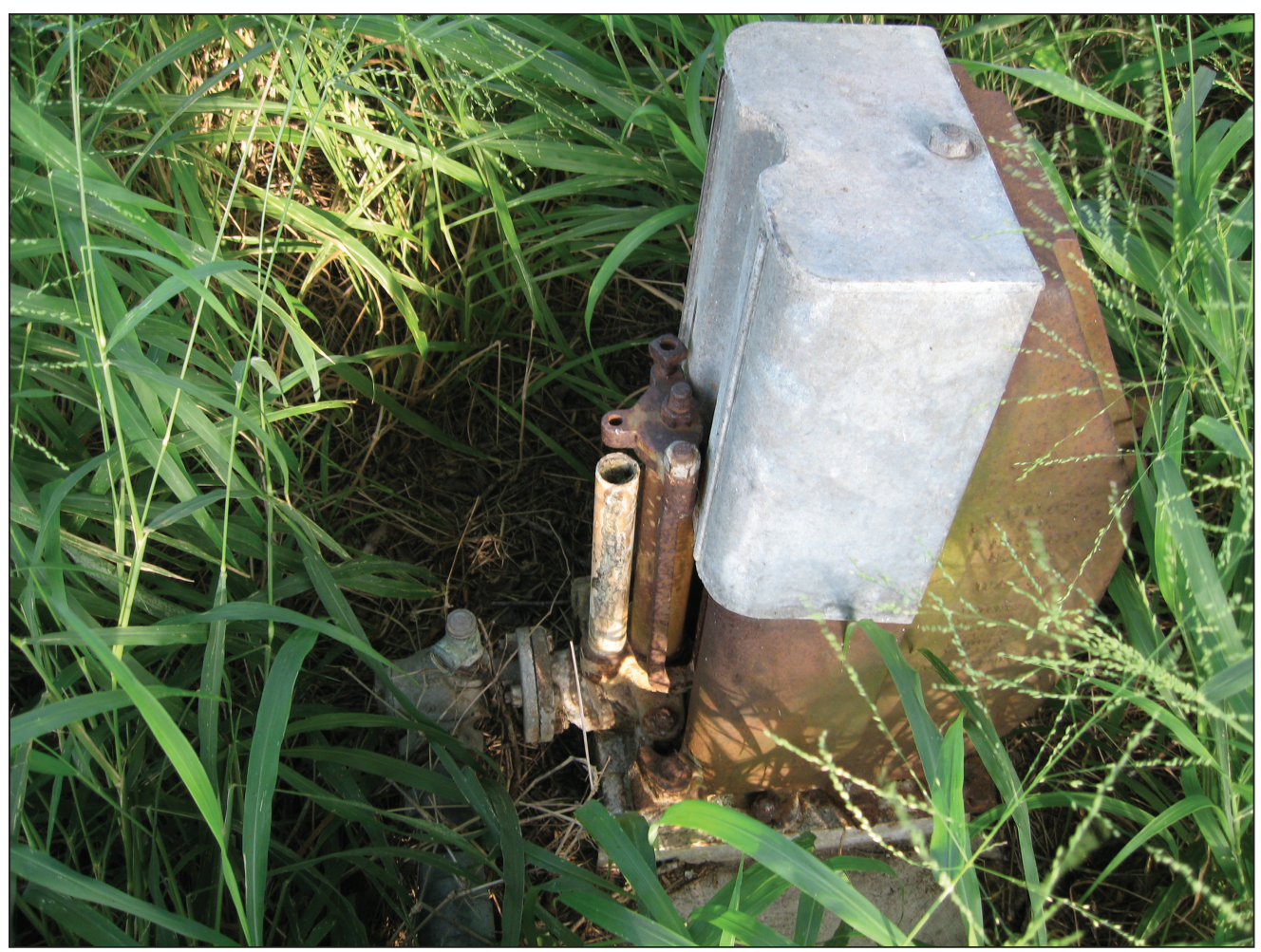

Figure 5-6. Windmill water pump located within site 41SP116 boundaries; facing northwest.

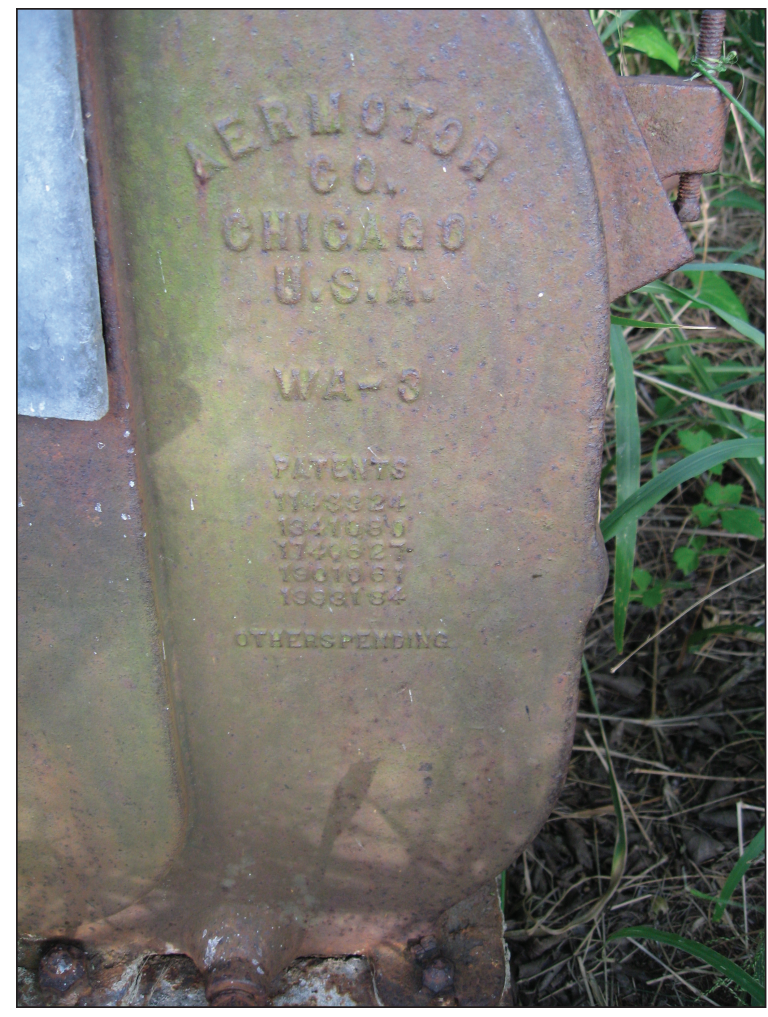

Figure 5-7. Close-up of water pump, displaying patents.

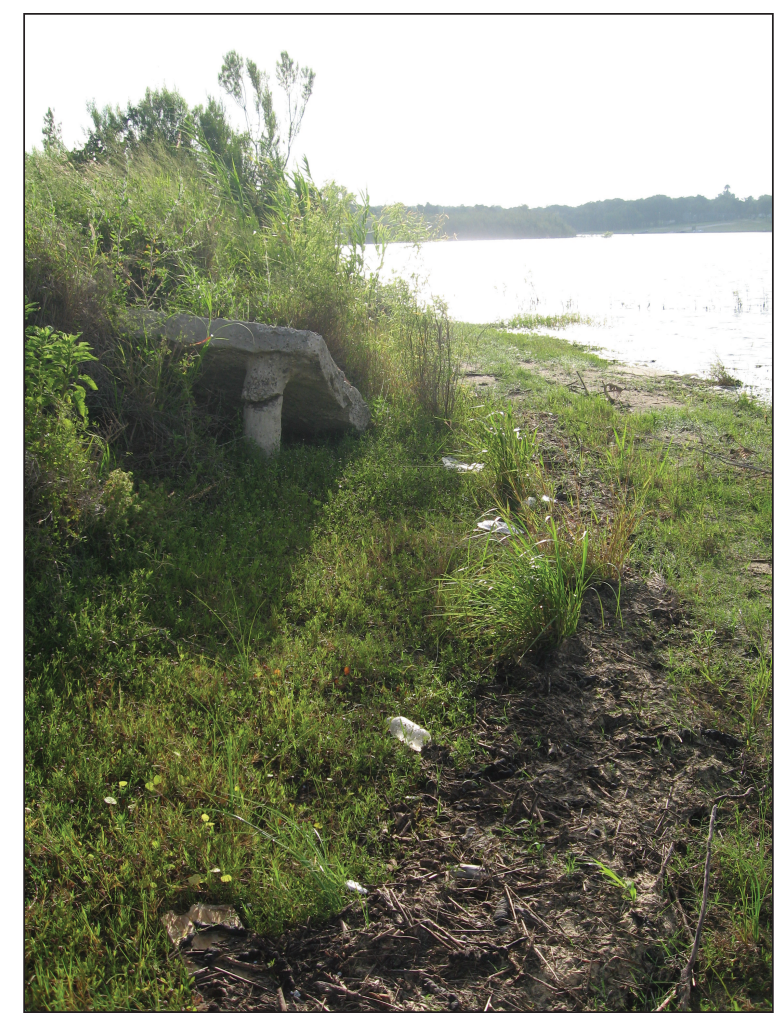

Figure 5-8. Concrete boat landing; facing southeast. 


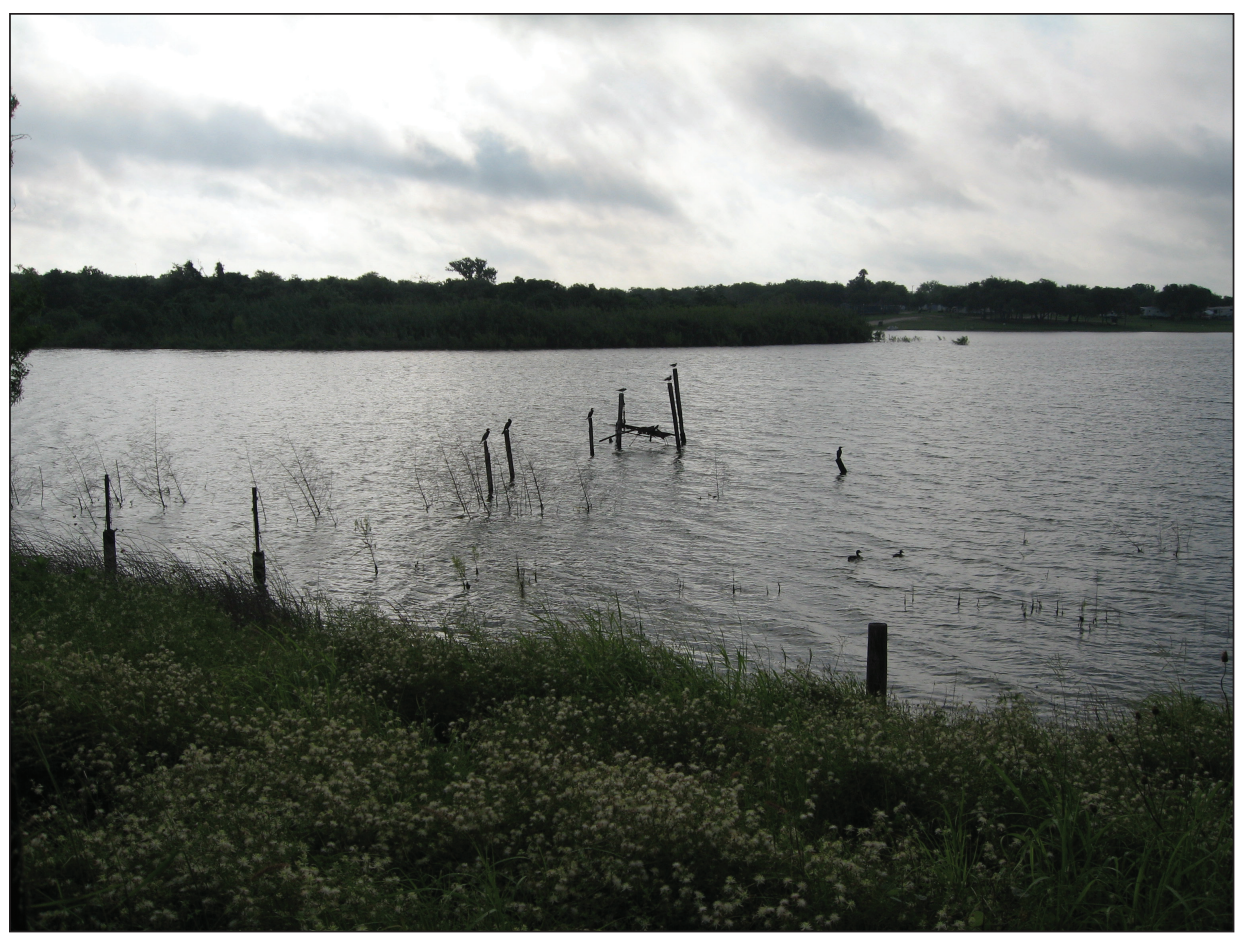

Figure 5-9. Remains of wooden boat pier; facing southeast.

concluded during these first investigations that these remains are the foundation of a domestic structure. Boes stated in his 1991 State of Texas Archeological Site Data Form that "a 1920s farm is said to have been here but the whereabouts of those structures has since been forgotten" (Boes 1991).

The site was revisited and reassessed by CAS archaeologists (Figure 5-10). With the exception of a few sparse trees spread out across the area, the slope area upon which the foundation is located is absent of the natural surrounding scrub vegetation. Ground surface visibility was less than 20 percent with exposed ground surfaces consisting of compact loams. The surface area surrounding the exposed foundation was visually inspected for historic remains; however, only modern garbage debris was noted. Three shovel tests (ST 104, ST 105, and ST 106) were excavated in the area of the exposed foundation. ST 104, to the north of the foundation, was excavated to a depth of $60 \mathrm{cmbs}$ upon which sterile soil levels were encountered. Artifacts recovered from this shovel test included nails and glass. ST 105 was excavated to the east of the foundation and encountered the caliche bedrock at $48 \mathrm{cmbs}$. Recovered artifacts from this shovel test included charcoal and brick fragments. ST 106 was excavated to the southwest of the exposed portion of the foundation to uncover the buried portion of this feature, which was encountered at 40 cmbs. Recovered cultural artifacts from this shovel test included nails.

A cement block and a piece of metal (possibly associated with the cement block) were identified approximately $75 \mathrm{~m}$ to the southwest of the exposed foundation (Figure 5-11). The cement block appears to lie even with the surrounding surface and is not clearly visible. This additional feature was recorded and photographed. A site boundary for $41 \mathrm{SP} 178$ was redrawn to follow the natural hill slope of the area that includes the cement block, the piece of metal, and the previously identified exposed foundation. The 


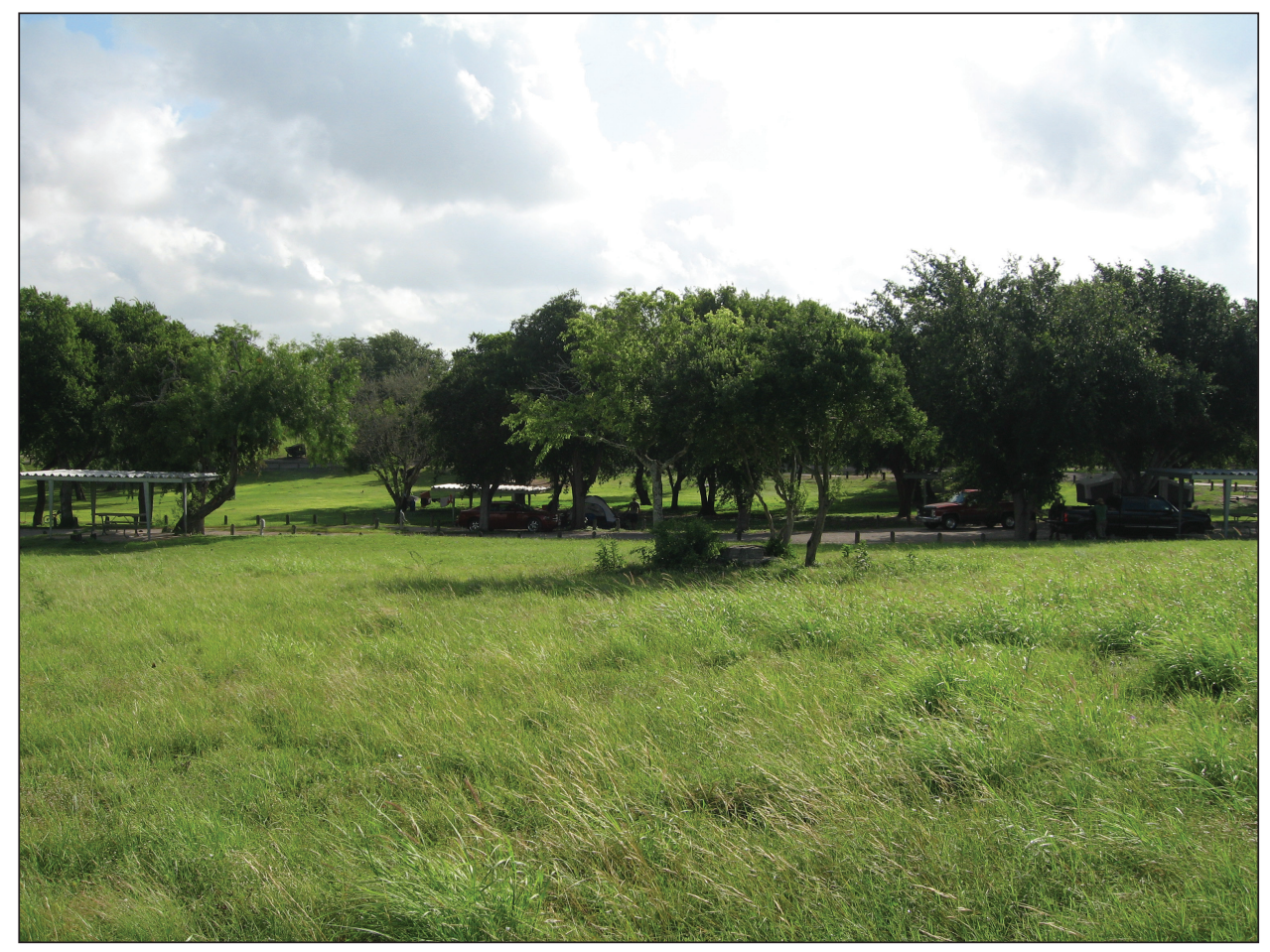

Figure 5-10. Overview of 41SP178; facing north.

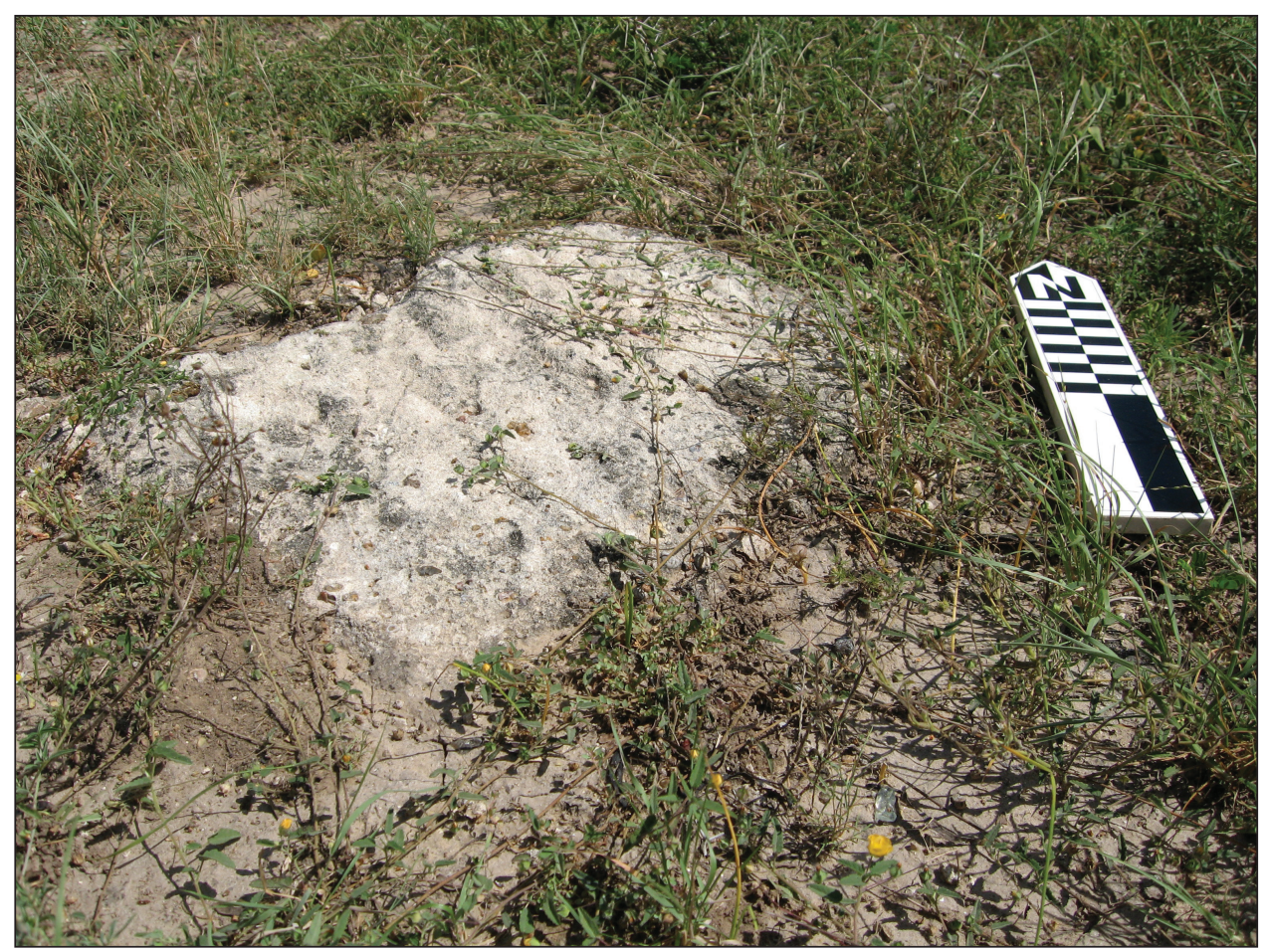

Figure 5-11. Cement block located near 41SP178 foundation feature; facing north. 


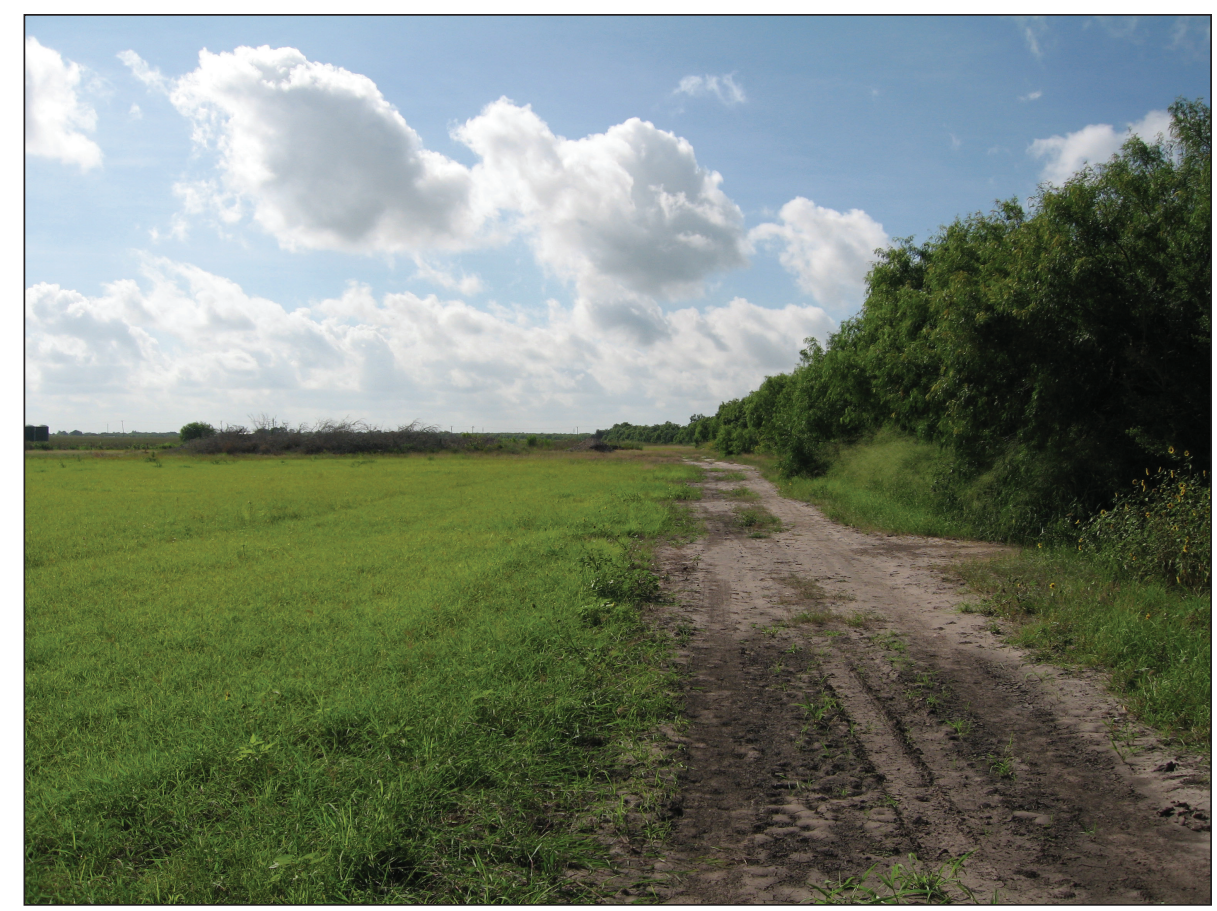

Figure 5-12. Overview of 41SP202; facing southeast.

foundation may correspond to the location of a CCC structure identified on a CCC map of the area (Figure D-2, Appendix D). This historic map was then overlaid on a current map of the park to discern if the identified foundation can be linked to a once-existing CCC structure (Figure D-4, Appendix D).

\section{SP202}

Archaeological site 41SP202 was identified as a lithic scatter of unknown age by Marek in 2002. Marek contends that the boundaries of the site extend to the southwest into a wooded section of park property. Only the portion located within the 50-acre parcel surveyed by Marek was investigated in 2002. This portion was determined ineligible for SAL or NRHP listing. The portion extending southward was not evaluated during Marek's survey.

Archaeologists from CAS revisited 41SP202 during investigations (Figure 5-12). The site is located in an open field covered with mediumtall grasses with surface visibility less than 20 percent. Traces of a dirt road lie along the southwestern edge of the open field and through the southwestern portion of the site. The area does not appear to have been plowed or irrigated recently and the sandy loam soils were hard and compact. Lithic debris (flakes, chert chunks) was observed on the surface of the dirt road and in areas where the surface was visible in the open grass field. Locations containing visible surface artifacts conformed to the site boundaries recorded by Marek in 2002. Piles of mulch, vegetation, trees, brush, building materials and logs were observed along the dirt road and in the open grass field. Two lithic tools (Scrapers A and Utilized Flake B; Figures 5-13 and 5-14) were recovered from a concentration of surface lithic materials. These artifacts were collected and their locations were plotted with a handheld GPS unit. ST 124 was excavated to $50 \mathrm{cmbs}$ in this area, but did not contain any cultural materials. Two additional lithic tools (Scraper C and Scraper 


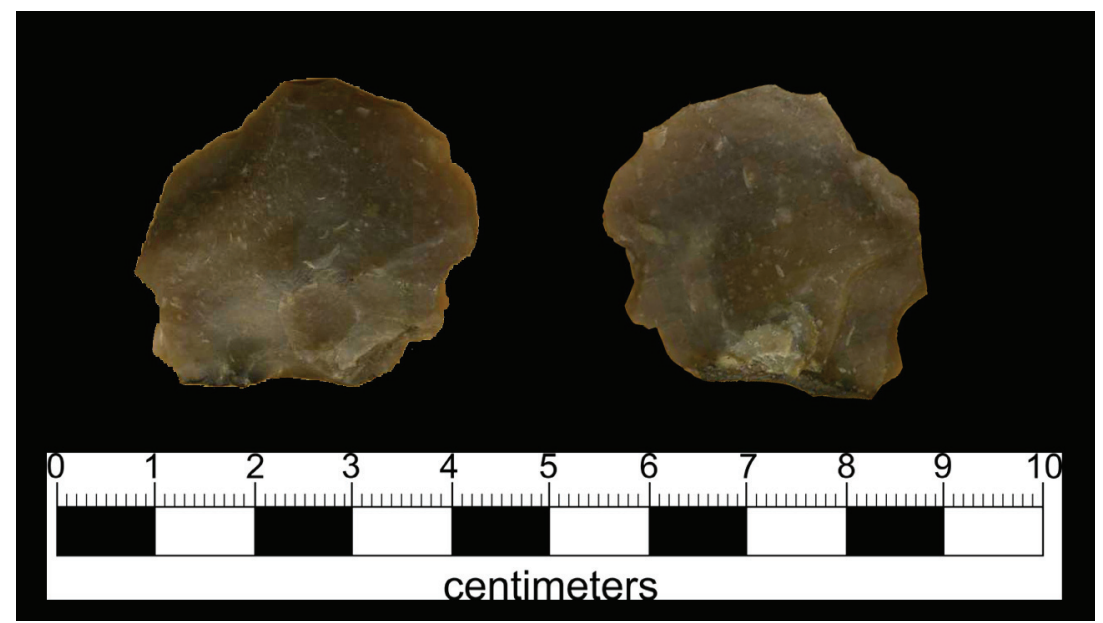

Figure 5-13. Lithic tool (Scraper A) from surface of ST 124, 41SP202; ventral side shown on left, dorsal on right.

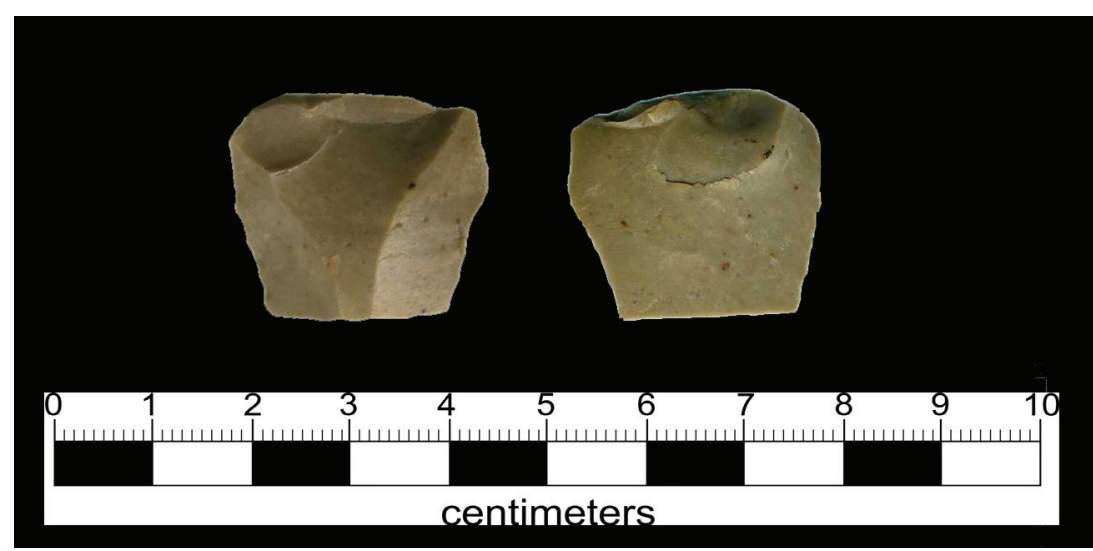

Figure 5-14. Lithic tool (Utilized Flake B) from surface of ST 124, 41SP202; ventral side shown on left, dorsal on right.

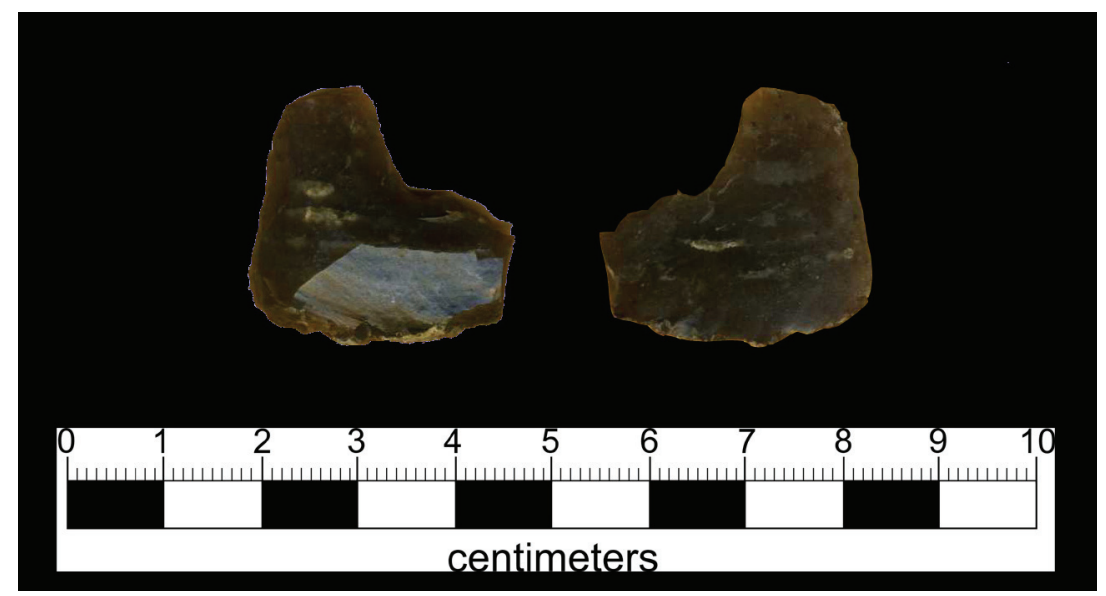

Figure 5-15. Lithic tool (Scraper C) from surface of ST 124, 41SP202; ventral side shown on left, dorsal on right. 
D) were collected from surface contexts (Figures 5-15 and 5-16).

The wooded area to the immediate southwest of the site was subject to investigations as Marek contends that a portion of the uninvestigated site extends in this direction. Five shovel tests (ST 107, ST 108, ST 109, ST 123, and ST 125) were

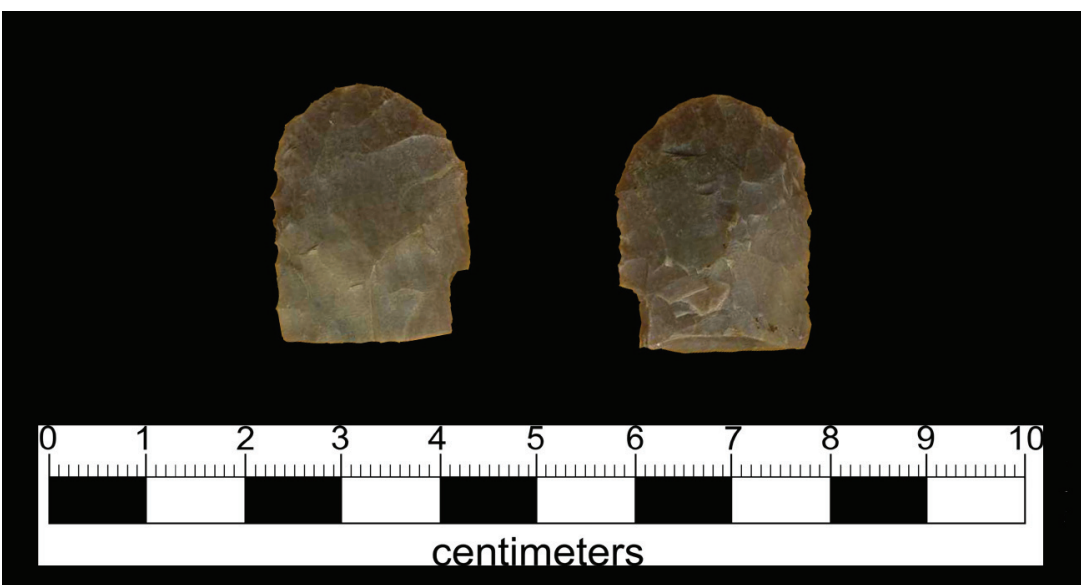

Figure 5-16. Lithic tool (Scraper D) from surface of ST 124, 41SP202; ventral side shown on left, dorsal on right. excavated within the tree line to the south of the site centroid and lithic tool collection site. All shovel tests were excavated to $50-55 \mathrm{cmbs}$ through sandy loam soil; no artifacts were encountered. It is therefore believed that the site does not extend to the south into the wooded area.

\section{SP227}

41SP227 wasrecorded by TPWDarchaeologist Chris Ringstaff in 2007 (Ringstaff 2007a). The

Refectory building to the shore line. Vegetation upon the peninsula is characterized by dense thorny vegetation with surface visibility less than 3 percent in areas away from the heavily traversed trail. Surface visibility on the trail was 100 percent and consisted of exposed caliche bedrock. The peninsula upon which the site is located was traversed following transect lines spaced approximately 15-20 m apart and the surface of the site was visually inspected. Siliceous/cherty site was described as a Late Archaic lithic procurement site and possible open campsite located atop a gravel-capped point immediately south and southeast of the park's Depression-era CCC Refectory building.

Archaeologists from CAS revisited the site and noted that it lies on a heavily vegetated peninsula directly south of the CCC Refectory building (Figure 5-17). The site is bisected by a heavily utilized public trail that runs north to south from the

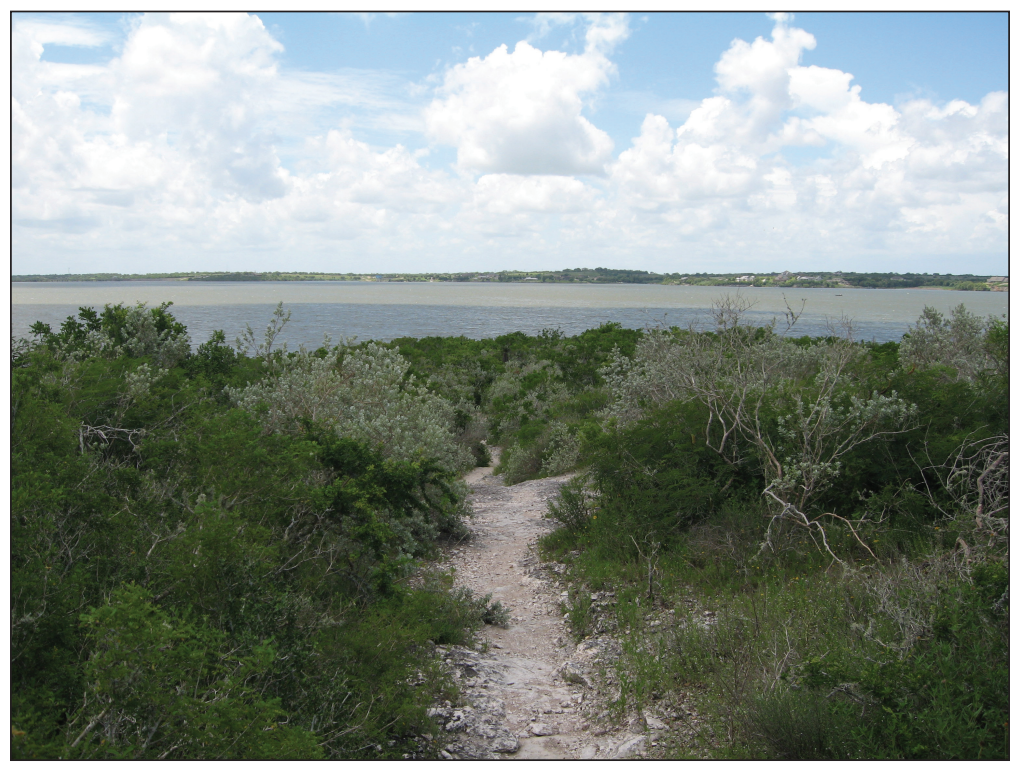

Figure 5-17. Overview of 41SP227; facing south. 


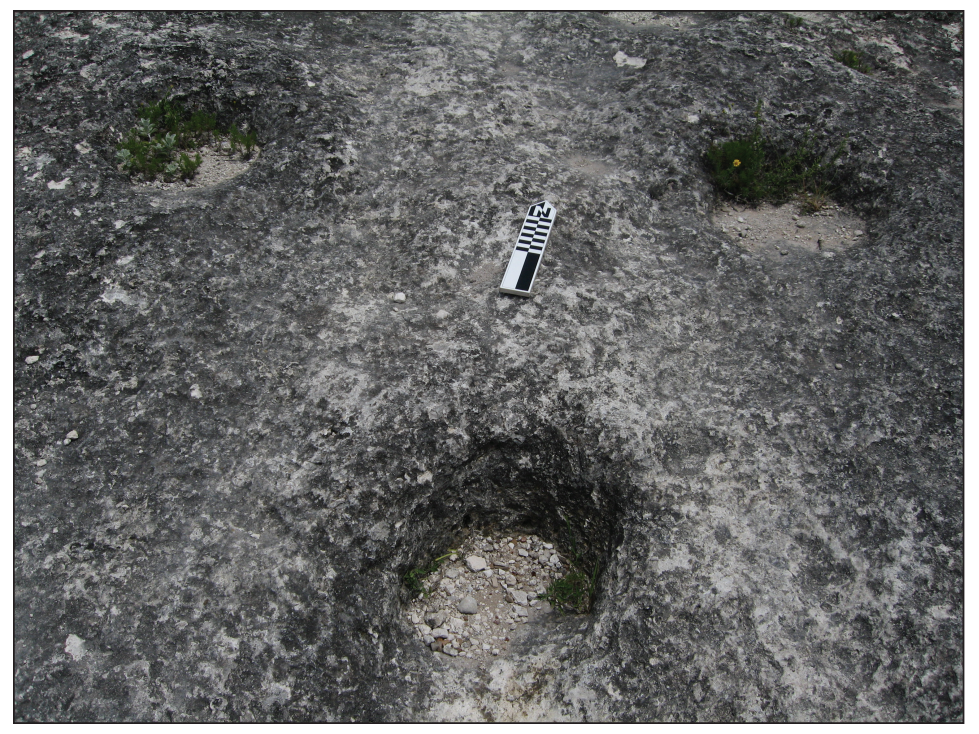

Figure 5-18. Possible bedrock grinding mortars; facing north.

2007b), as a scatter of historicera artifacts and prehistoric lithic scatter/open campsite. An area of dense lithic debitage was noted in the southern portion of the site during his investigations. Artifacts noted during Ringstaff's investigations include a possible Martindale point, chert cores, biface fragments, lithic debitage, solarized glass shards, and whiteware ceramic sherds. While the majority of the site lies within the cleared area of the south camping loop, possible shallow deposits were noted in the wooded area to the northwest of the open

gravels, tested cobbles, and lithic debitage were observed on visible surface areas. No diagnostic artifacts were observed or collected. The majority of artifacts were seen along the edges of the traversed trail, but several were observed in the dense brush. An area containing possible bedrock grinding mortars was identified, recorded, and investigated (Figure 5-18). After cleaning out the holes it was determined that they were solution cavities created by water accumulation upon the caliche/limestone bedrock. The site boundary for 41SP227 was redrawn to include the distribution of noted surface artifacts (lithic debitage and tested cobbles). Due to the rocky nature of the peninsula and the lack of soil deposition, no shovel tests were excavated in the heavily vegetated areas.

\section{SP228}

41SP228 was recorded by TPWD archaeologists Chris Ringstaff in 2007 (Ringstaff

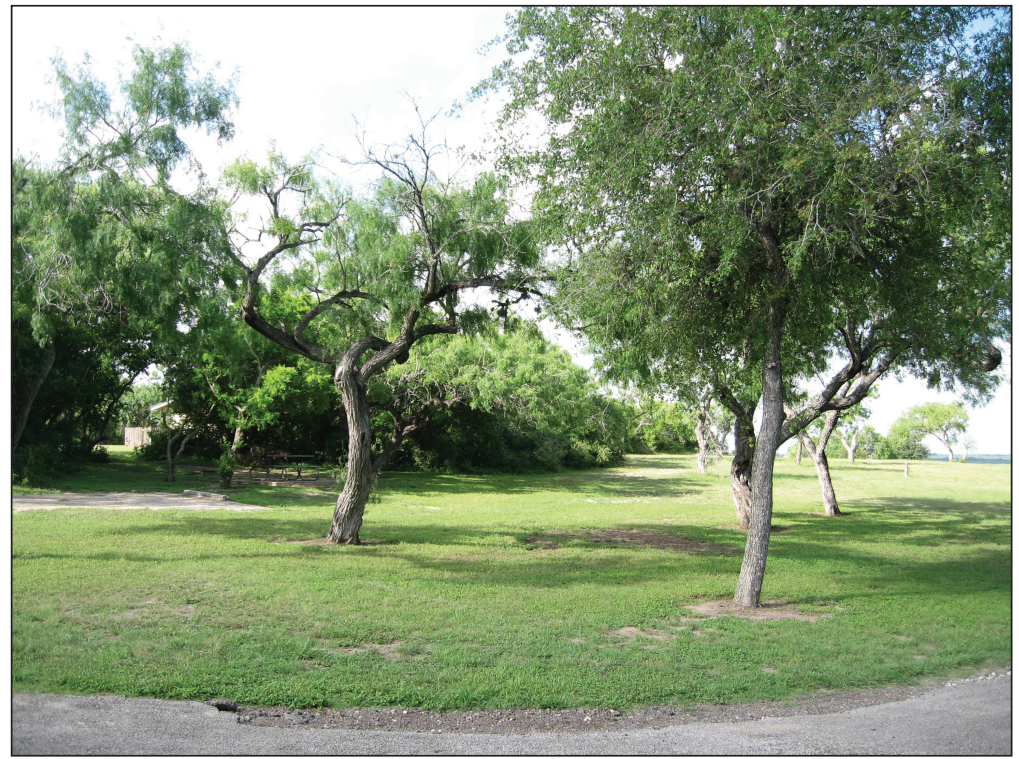

Figure 5-19. Overview of site 41SP228; facing south. 
percent. Locations of artifacts were pin flagged and three shovel tests were excavated in the area.

During the examination of the wooded area to the immediate northwest of the site, a cut bank was encountered and two profile descriptions were recorded (Figure 5-20). Additionally, three cement blocks (one with an iron protrusion, Figure 5-21) were observed and recorded, in addition to various non-diagnostic historic/modern debris. One shovel test, ST 76, was excavated in this heavily wooded area, but no subsurface cultural remains were encountered. No prehistoric artifacts were observed on the surface nor

\section{LCCSP \\ Profile 1 \\ Erosioan Channel \\ 41SP228 \\ $6 / 15 / 2010$ \\ R. Z. Seldon}

\begin{tabular}{|c|c|}
\hline $\begin{array}{l}\text { Depth } \\
\text { Below } \\
\text { Surface }\end{array}$ & Soil Description \\
\hline $0-10$ & \multirow{3}{*}{$\begin{array}{l}\text { 7.5YR2.5/1 (Black) Sandy Loam } \\
\text { (firm), blocky subangular, }<1 \% \\
\text { mottling, rootlets }\end{array}$} \\
\hline 10-20 & \\
\hline 20-30 & \\
\hline $30-40$ & $\begin{array}{l}\text { 7.5YR3/2 (Dark Brown), sandy loam } \\
\text { (friable), grandular fine }\end{array}$ \\
\hline $40-50$ & \multirow{5}{*}{$\begin{array}{l}\text { 7.5YR3/3 (Dark Brown) sandy loam } \\
\text { (loose), grandular fine, } 5 \% \text { mottled }\end{array}$} \\
\hline $50-60$ & \\
\hline $60-70$ & \\
\hline $70-80$ & \\
\hline 80-90 & \\
\hline $90-100$ & \multirow{2}{*}{$\begin{array}{l}\text { 7.5YR4/2 (Brown) Sandy (loose), } \\
\text { grandular med }\end{array}$} \\
\hline $100-110$ & \\
\hline $110-120$ & \multirow{6}{*}{$\begin{array}{l}\text { 7.5YR4/4 (Brown), sandy (loose), } \\
\text { grandular fine, roots }\end{array}$} \\
\hline $120-130$ & \\
\hline $130-140$ & \\
\hline 140-150 & \\
\hline $150-160$ & \\
\hline $160-170$ & \\
\hline $170-180$ & \multirow{2}{*}{$\begin{array}{l}\text { 7.5YR5/4 (Brown), sandy (loose), } \\
\text { grandular fine, } 5 \% \text { mottles }\end{array}$} \\
\hline 180-190 & \\
\hline
\end{tabular}

LCCSP

Profile 2

Erosioan Channel

41SP228

$6 / 15 / 2010$

J. Hooge

\begin{tabular}{|c|c|}
\hline $\begin{array}{l}\text { Depth Below } \\
\text { Surface }\end{array}$ & Soil Description \\
\hline $0-10$ & \multirow{2}{*}{$\begin{array}{l}\text { 10YR2/2 (Black), sandy loam (loose) } \\
\text { grandular fine, rootlets }\end{array}$} \\
\hline $10-20$ & \\
\hline $20-30$ & \multirow{2}{*}{$\begin{array}{l}\text { 10YR3/2 (Dark Brown), sandy loam } \\
\text { (loose), grandular fine, roots }\end{array}$} \\
\hline $30-40$ & \\
\hline $40-50$ & \multirow{4}{*}{$\begin{array}{l}\text { 10YR4/2 (Dark Brown), sandy loam } \\
\text { (loose), grandular fine, roots }\end{array}$} \\
\hline $50-60$ & \\
\hline $60-70$ & \\
\hline $70-80$ & \\
\hline 80-90 & \multirow{3}{*}{$\begin{array}{l}\text { 10YR4/3 (Brown), sandy loam } \\
\text { (loose), grandular fine, roots }\end{array}$} \\
\hline $90-100$ & \\
\hline 100-110 & \\
\hline $110-120$ & \multirow{4}{*}{$\begin{array}{c}\text { 10YR5/3 (Brown), sandy loam } \\
\text { (loose), grandular fine, } 5 \% \text { mottles, } \\
\text { roots }\end{array}$} \\
\hline $120-130$ & \\
\hline $130-140$ & \\
\hline $140-150$ & \\
\hline $150-160$ & \multirow{2}{*}{$\begin{array}{l}\text { 10YR5/4 (Brown), sandy loam } \\
\text { (loose), grandular fine, roots }\end{array}$} \\
\hline $160-170$ & \\
\hline $170-180$ & \multirow{2}{*}{ Unexcavated } \\
\hline $180-190$ & \\
\hline
\end{tabular}

Figure 5-20. Profiles of cut banks at 41SP228. 


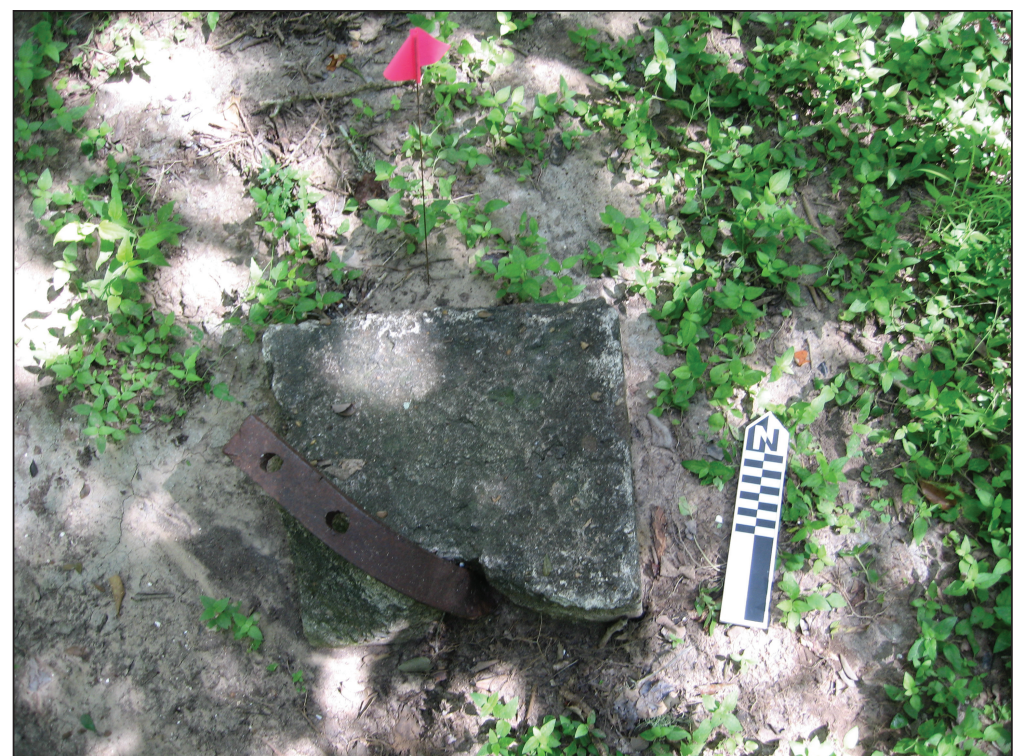

Figure 5-21. Concrete block with iron protrusion, 41SP228.

flake and a single lithic tool were observed, recorded, and collected from the surface of the cleared camping area (Figure 5-22). An additional shovel test, ST 77, was excavated on the far northeastern boundary of the site, but no subsurface cultural materials were encountered; only snail shells were recovered.

\section{Newly Identified Sites}

\section{$41 S P 235$}

A lithic scatter was encountered and recorded along the southern park road between

encountered during excavations of shovel tests in the wooded area. The site boundaries of 41SP228 were extended to include the locations of the historic/modern surface artifacts observed within the wooded portion.

Several chert debitage flakes, however, were observed on the surface of the cleared camping area and appeared in a dense concentration along the top of the ridge that extends from the northeast to the southwest through the cleared camping loop area. A single shovel test, ST 75 was excavated in the densest concentration of those lithic artifacts. Prehistoric lithic materials $(n=7)$ were encountered and collected between the surface and a depth of 50 cmbs. A complete amber bottle was recovered between 10 and 20 cmbs. In addition, one large chert

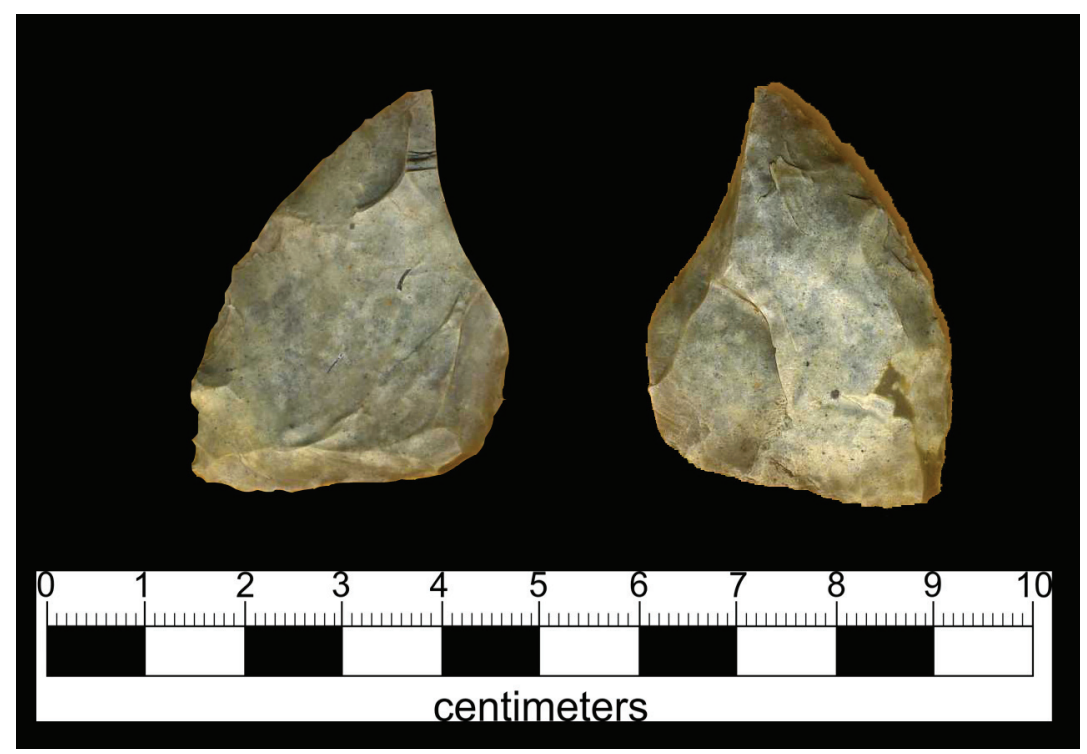

Figure 5-22. Lithic tool (Scraper) from surface of 41SP228; ventral side shown on left, dorsal on right. 
contained cultural artifacts. Cultural artifacts consisted of lithic debitage and one tested cobble; no diagnostic artifacts were encountered. Artifacts extended from the surface to a depth of up to $50 \mathrm{cmbs}$. The site appears to be a prehistoric lithic scatter and a TexSite form (Appendix C) was completed for this site. A more detailed presentation of the analysis of recovered lithic artifacts from this site is presented in Chapter 6: Artifacts.

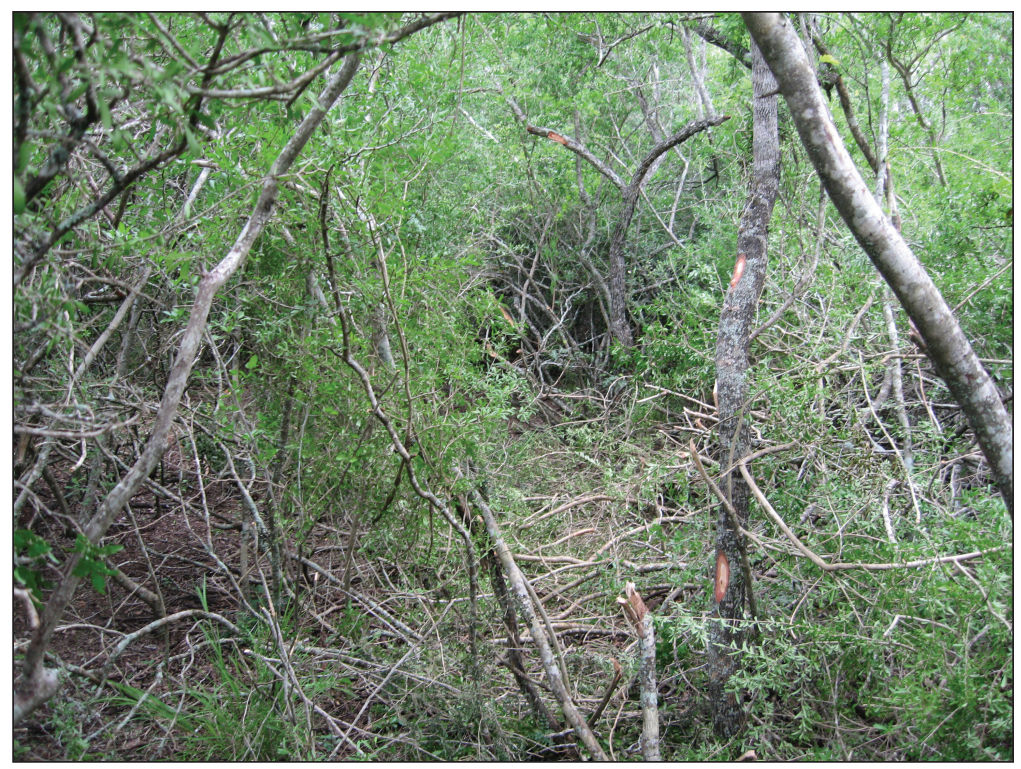

Figure 5-23. Overview of 41SP235; facing west.

\section{SP234}

During investigations at Lake Corpus Christi State Park, archaeologists from CAS revisited the Refectory Complex area. The area and associated features/structures were recorded, photographed and mapped (Figure 5-24). Structures recorded included the Refectory building, the Grand Stair Case (Figure 5-25), and the Pump House (Figure 5-26). Three shovel tests were excavated on the grounds of the Refectory Building; ST 98, ST 99 and ST 100. ST 100 was

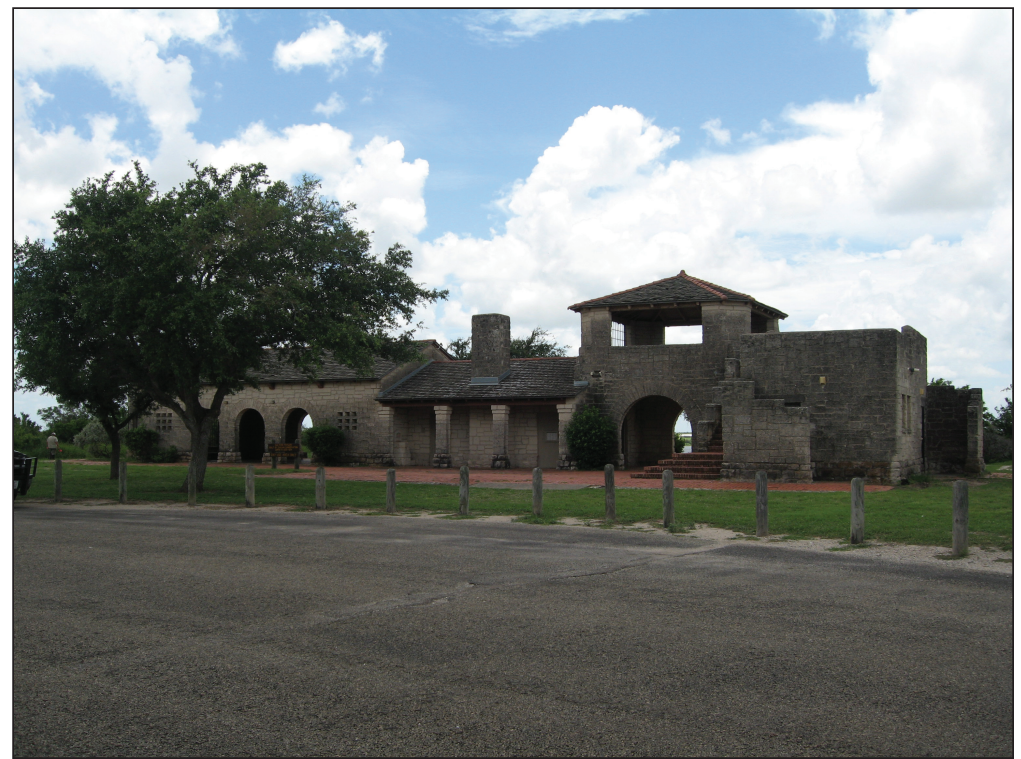

Figure 5-24. Refectory building; facing southeast. excavated to the immediate southeast of the Refectory Building and encountered a caliche bedrock layer at approximately 14 cmbs. ST 98 was excavated in the middle of the lawn area that extends from behind the Refectory Building to the lake edge. This unit was dug to a depth of $42 \mathrm{cmbs}$ with no encountered cultural artifacts. ST 99 was excavated adjacent to the boundary of

41SP227 to the south of the Refectory Building. This unit was excavated to a depth of $52 \mathrm{cmbs}$, where caliche bedrock was encountered. An exhausted core was encountered at 20-30 cmbs and a large lithic flake was encountered at 40-50 $\mathrm{cmbs}$. These recovered artifacts may be related to the adjacent prehistoric site 41SP227. A machinemade, art deco-style, Ball bottle was collected 


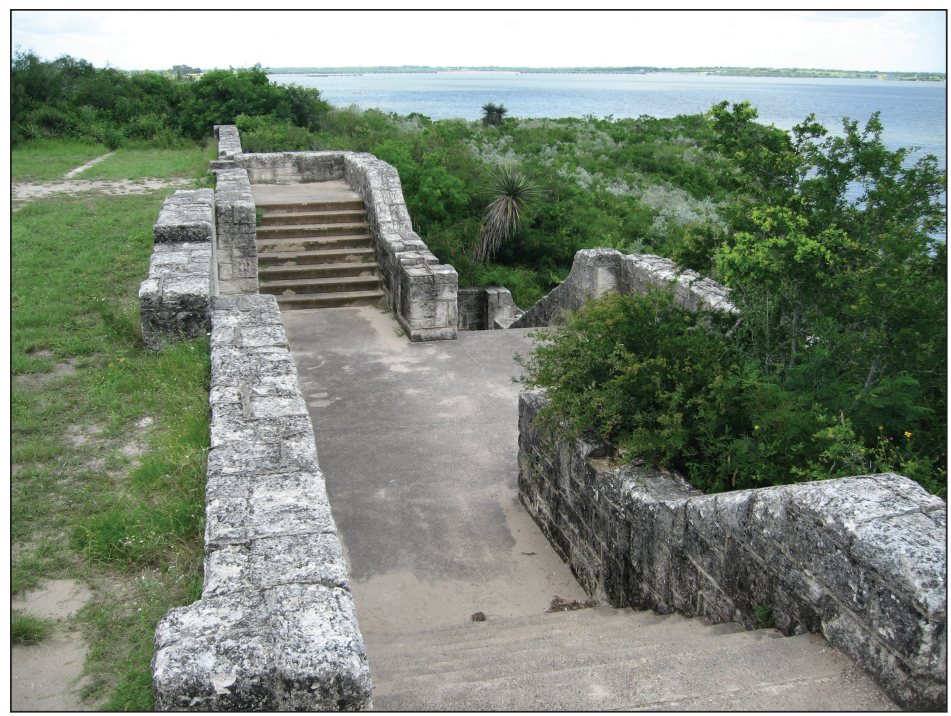

Figure 5-25. Stairwell southwest of refectory building; facing southeast.

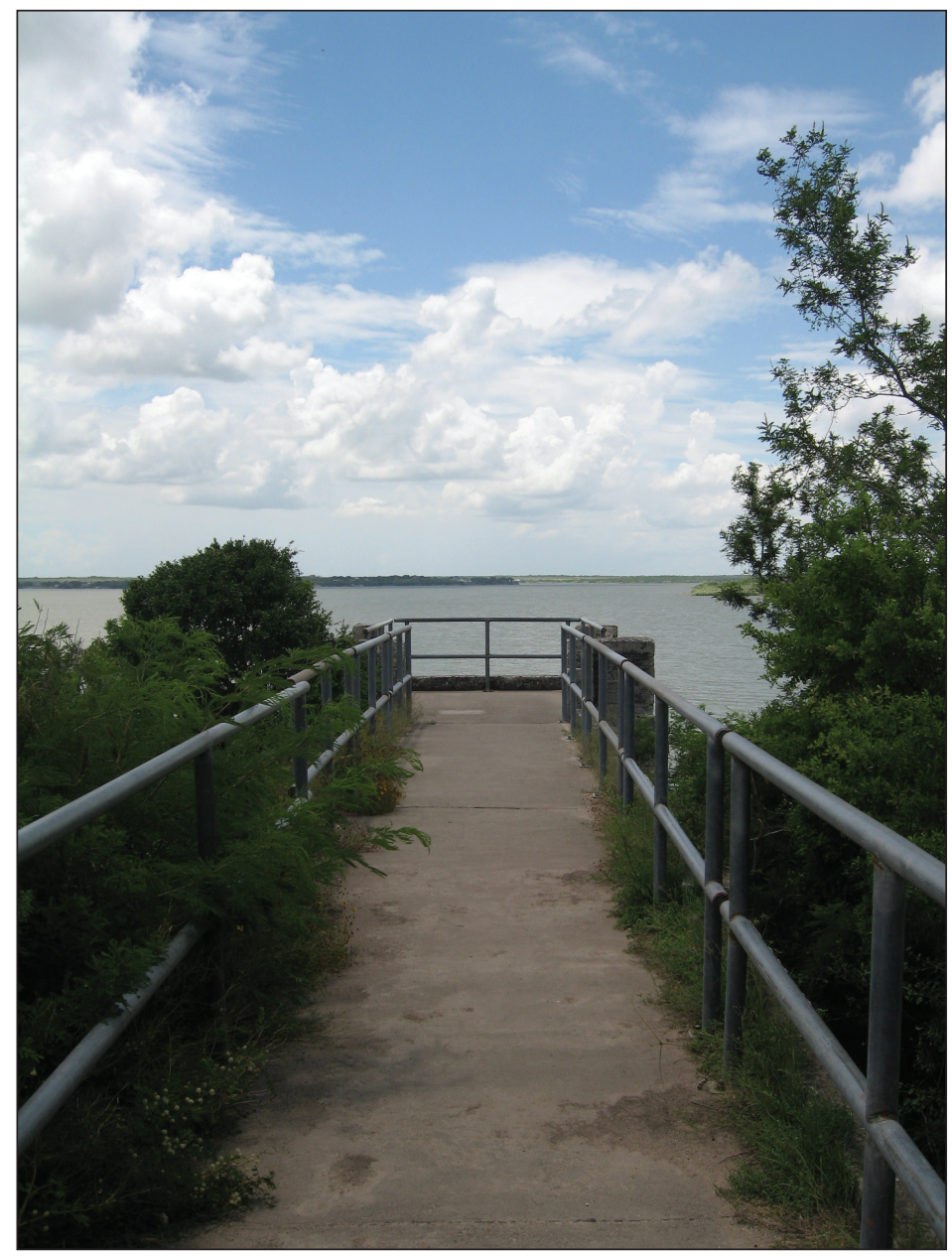

Figure 5-26. Pump house scenic overlook; facing northwest. from the surface of the lawn area behind the Refectory Building. A site boundary was then drawn for the CCC Refectory Complex that included the Refectory Building the Grand Staircase, the Pump House, and the excavated shovel tests. A TexSite form (Appendix C) was also completed for this site complex.

\section{Newly Identified CCC Feature}

\section{Culvert}

A feature that appears to be a CCC-era culvert was encountered during investigations along northern Park Road 25 (Figures 5-27, 5-28, and 5-29). This culvert is composed of cast calichecrete blocks set in a random-ashlar pattern (Steely 1999) similar to other CCC structures located within the park. The culvert extends approximately 14.4 m beneath Park Road 25 and acts as a water diversion channel. The northern side of the culvert was investigated in detail and an illustration was created (Figure 5-30).

The southern side was also investigated, but only photographs were taken of this portion of the culvert as it appears to have suffered some damage mostly resulting from the direction of flow of runoff water through the culvert. The northern portion of the culvert appears in pristine conditions as it has been protected by overlaying vegetation that was removed 


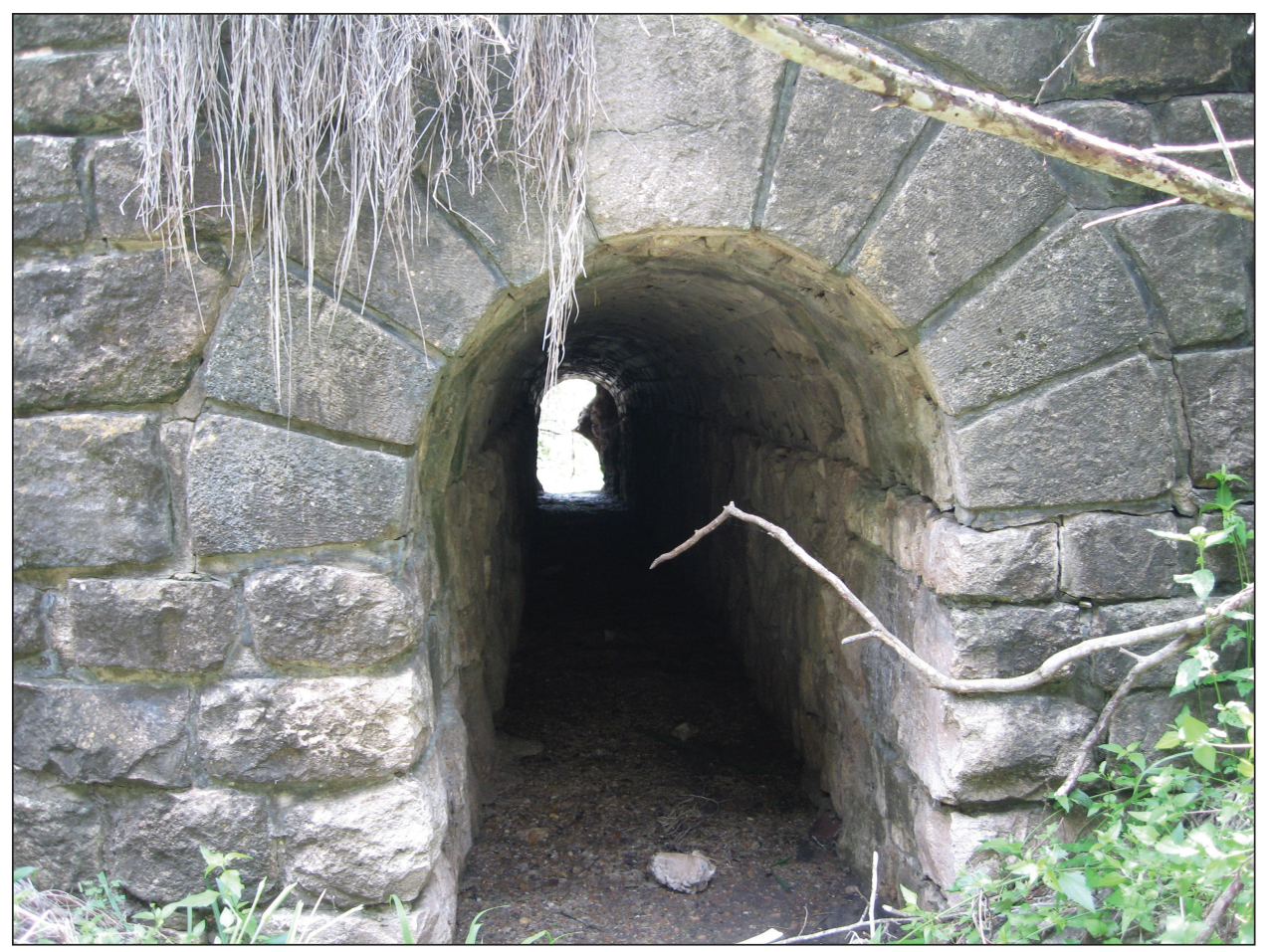

Figure 5-27. Exterior of north side of culvert; facing southwest.

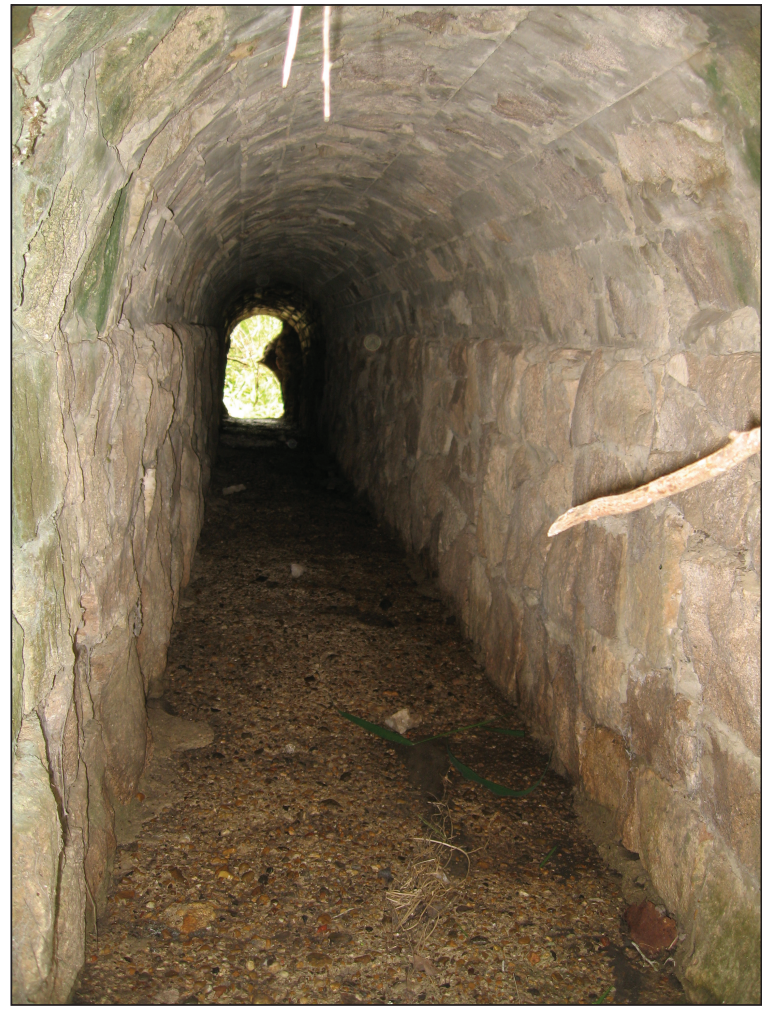

Figure 5-28. Culvert interior; facing southwest.

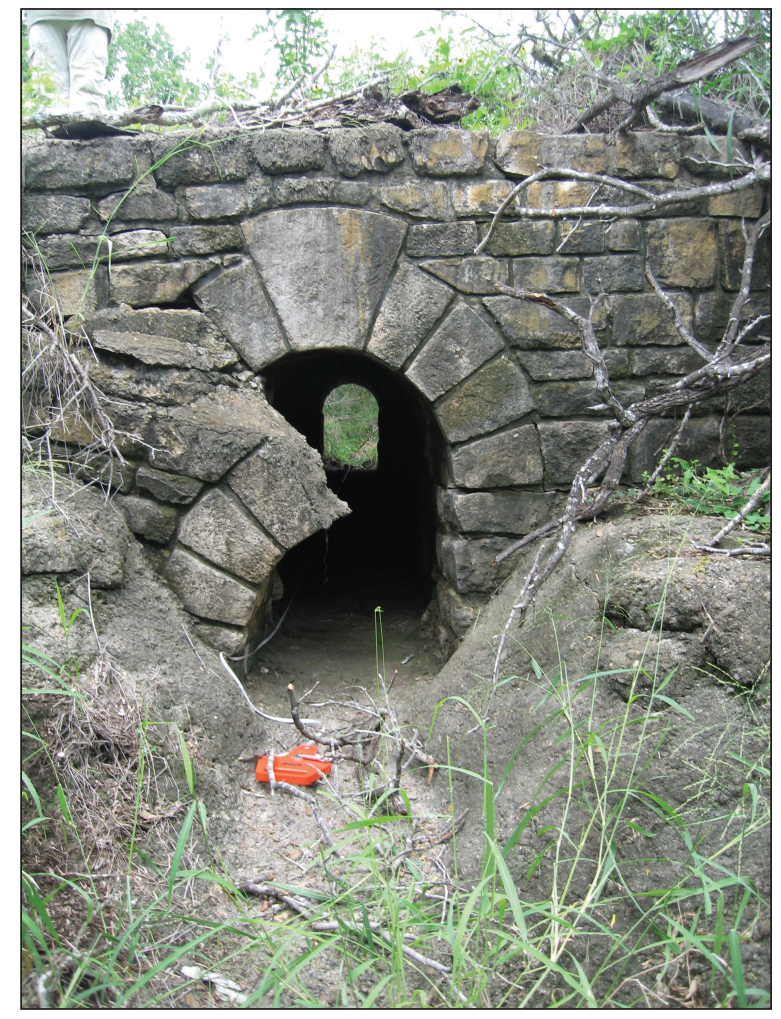

Figure 5-29. Exterior of south side of culvert; facing northeast. 


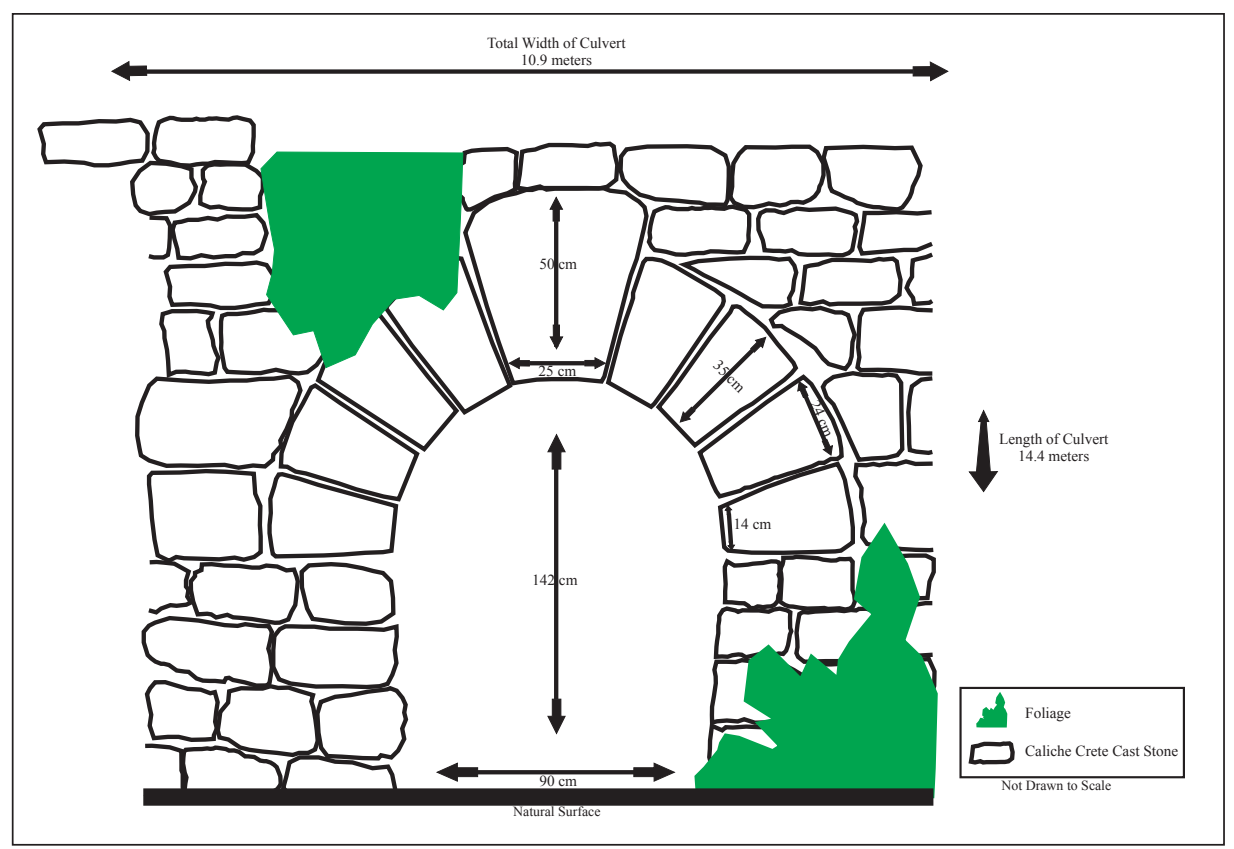

Figure 5-30. Detailed illustration of culvert.

during investigations. The opening of the northern side of the culvert is $90 \mathrm{~cm}$ wide and $142 \mathrm{~cm}$ tall and the entire construction of the northern side of the culvert extends approximately 10.9 m along Park Road 25 . Its unique construction includes a key stone above the entrances to both the northern and southern culverts.

The newly encountered culvert appears to be a previously unknown $\mathrm{CCC}$ feature within the park's boundaries. The report produced by Quimby and McCoy did not list this feature among those inventoried during their assessment of CCC Structures in Lake Corpus Christi State Park (Quimby McCoy 2008). The location of this feature was recorded with a submeter handheld GPS unit and plotted on a universal map of the project area. A review of the CCC Master Plan map of Lake Corpus Christi, clearly displays the location of this recently uncovered feature (Figure D-4, Appendix D).

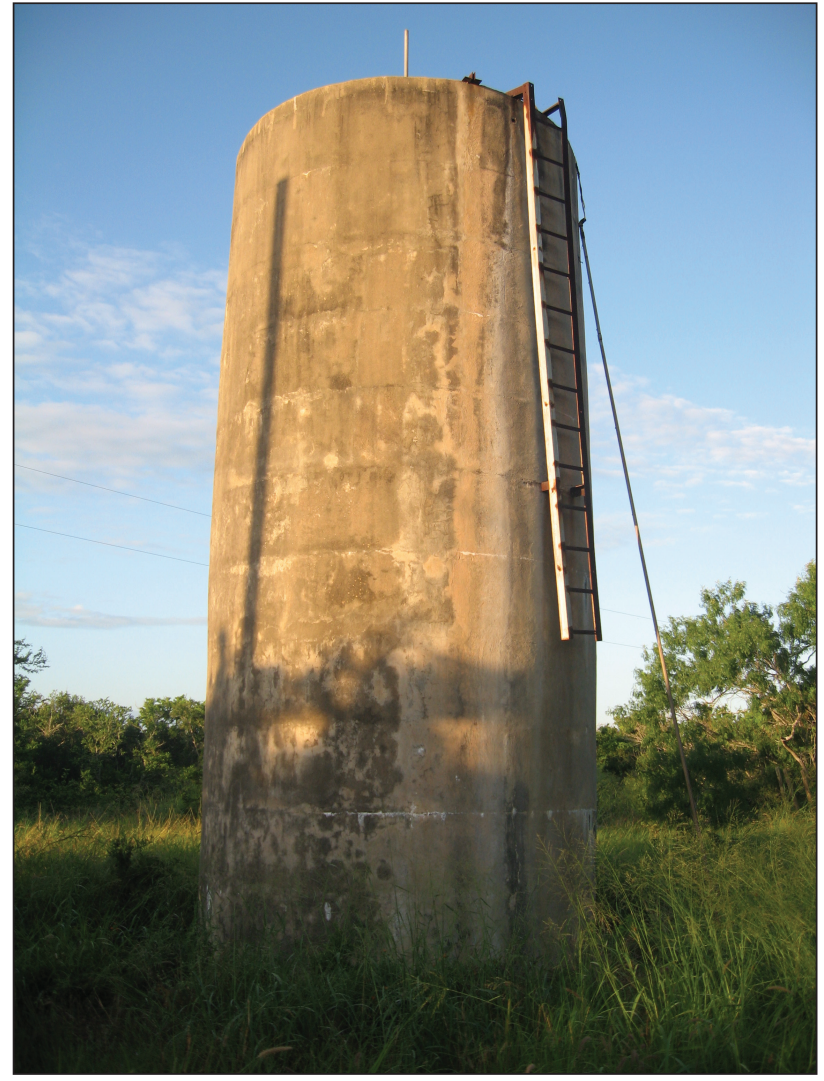

Figure 5-31. Possible CCC water tower; facing south. 


\section{Investigations of Possible CCC Features}

\section{Water Tower}

$\begin{array}{ccc}\text { Investigations } & \text { at } & \text { Lake } \\ \text { Corpus Christi State Park }\end{array}$ also included investigations of a Water Tower located approximately $170 \mathrm{~m}$ north of the CCC Refectory Building (Figure 5-31). The Water Tower appears to be similar to the concrete water tower identified at the Park Superintendent's Residence in the Quimby McCoy Report (Quimby McCoy 2008:22). The Quimby McCoy report describes the Superintendent's Residence water tower as constructed of poured concrete, standing approximately $25 \mathrm{ft}$ tall, and 10 $\mathrm{ft}$ in diameter. The report states that the water tower does not appear in the CCC drawings, but its construction may date to the construction of the residence in 1931 (Quimby McCoy 2008:22).

Current investigations of the Water Tower north of the CCC Refectory included mapping, photograph documentation and shovel test excavations (ST 88 and ST 87). Glass and road base materials were recovered from the shovel tests. During a visual inspection of the area surrounding the water tower, a pump house (Figure 5-32), a stock pile of metal BBQ grills (Figure 5-33) and a pile of chert stone road base (Figure 5-34) were discovered. The locations of these items were also recorded by a handheld submeter GPS unit and plotted on a universal map of the project area. Since the water tower northwest.

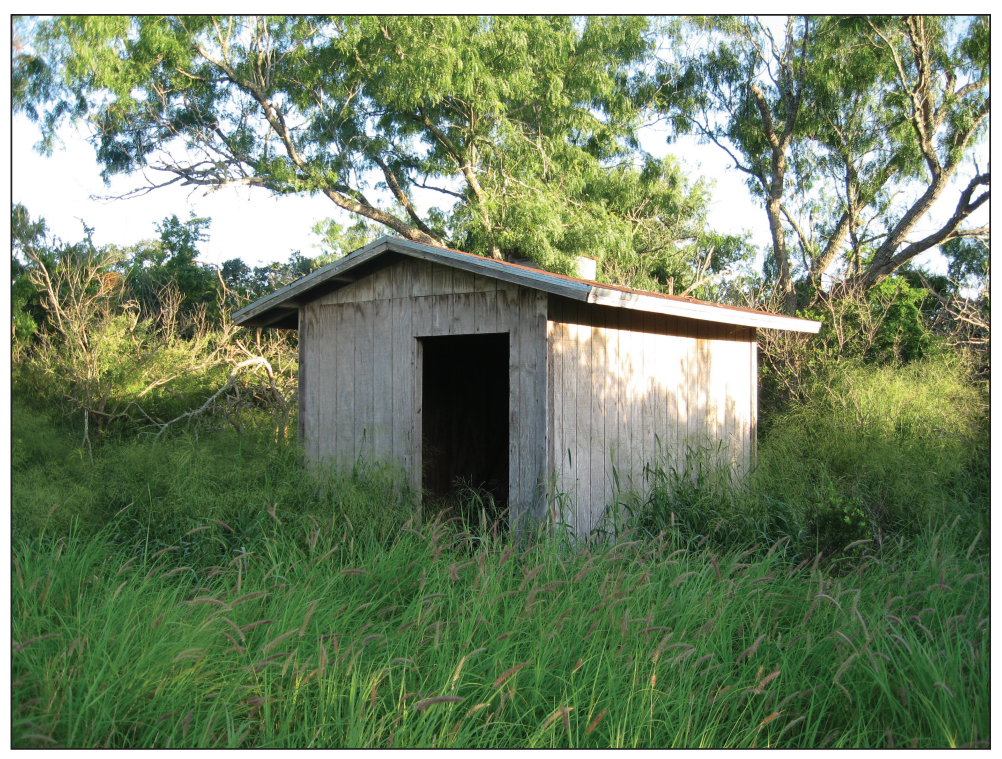

Figure 5-32. Pump house associated with water tower; facing

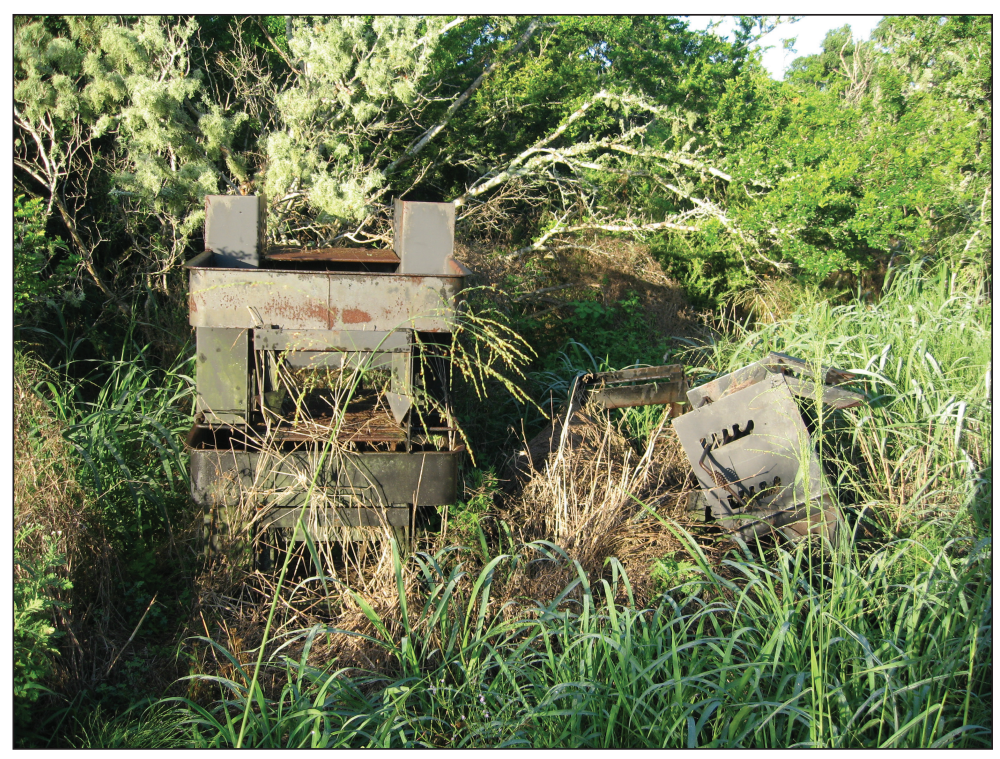

Figure 5-33. Stock pile of BBQ grills; facing northwest.

appears to be constructed in the same manner of the Superintendent's water tower, it is believed that the two are contemporaneous.

\section{Road in NW Corner}

During investigations, the remains of a set of roadways were uncovered in the far northwest corner of the park (see Figure 


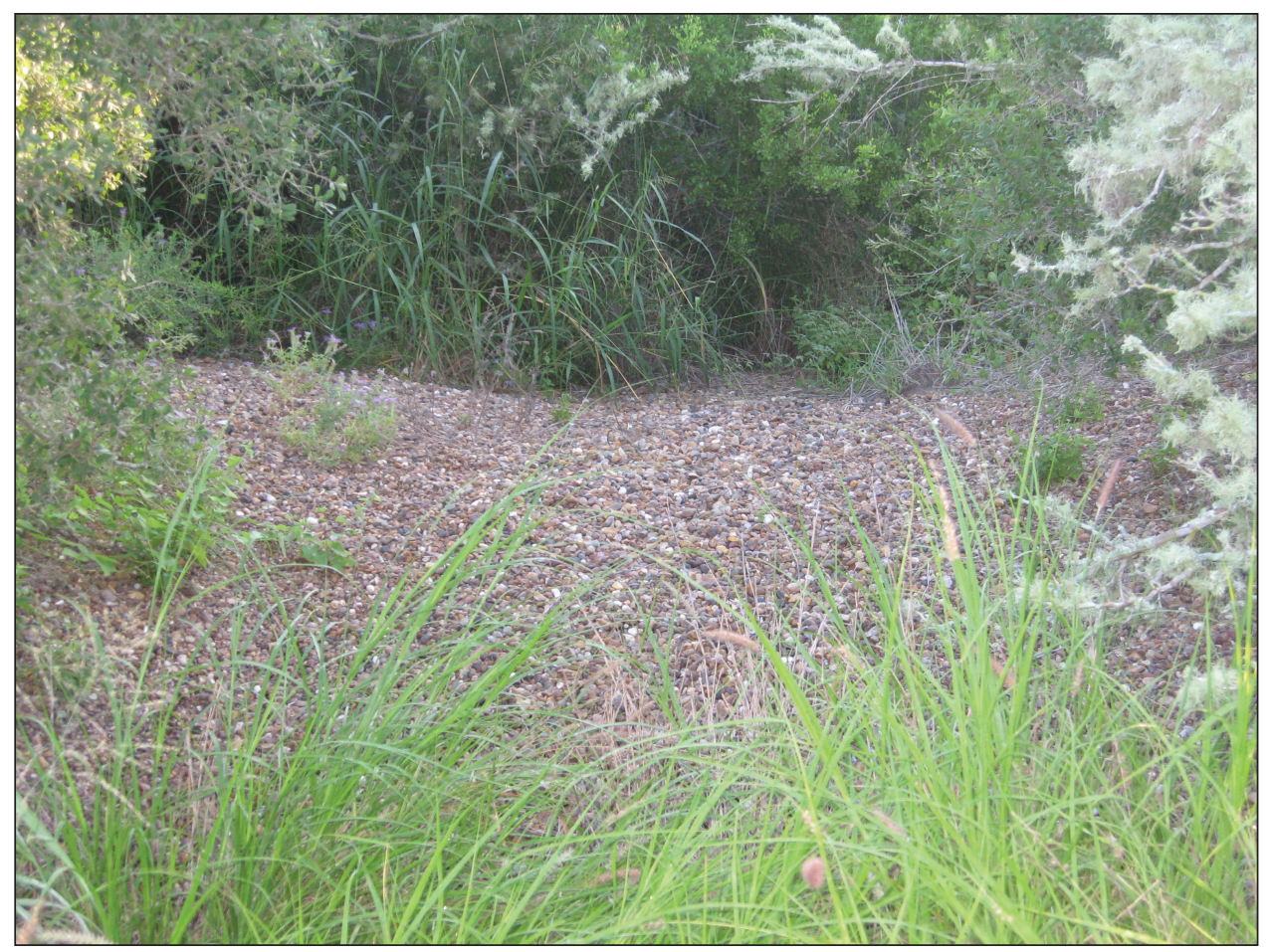

Figure 5-34. Chert stone road base pile; facing northeast.

E-10). This area was subject to intensive pedestrian survey as a structure (foundation) is noted on the 1979 topographic quadrangle map. Despite thorough investigations, no remains of a structure were located. A "Y" road segment was, however, uncovered during investigations of this area. A shovel test was also excavated next to the uncovered road segment (ST 120). This shovel test was excavated to a depth of 50 cmbs through sandy loams. With the exception of asphalt fragments that were recovered from the top level, no cultural material was encountered. As the road segment is not noted on the 1979 quad map, it most likely predates the late 1970s, and may possibly be a CCC era feature that may be evidence of the original park entryway as envisioned by CCC planners. 


\section{Chapter 6}

\section{Artifacts}

In total, 455 artifacts weighing 3,448.2 grams (g) were collected during cultural resources investigations of Lake Corpus Christi State Park. Collected artifacts were classified as building materials, ${ }^{14} \mathrm{C}$ samples, glass, lithics, metal, shell, and other (Appendix B). All artifacts encountereded during the excavation of shovel tests were collected, while only diagnostic artifacts encounter on the surface were retained. All artifacts were processed according to the stipulations set forth in the TPWD Archeology Laboratory Manual (Texas Parks and Wildlife Department 1995). Collected cultural materials were temporarily housed at CAS, with final curation at TPWD.

\section{Building Materials}

Artifacts classified as building materials included asphalt, brick fragments, calichecrete fragments, and mortar fragments. The majority of these building materials were collected from shovel test ST 105, excavated approximately $5 \mathrm{~m}$ to the east of the concrete foundation identified at archaeological site 41SP178. A fragment of road asphalt was collected from ST 120, excavated adjacent to the identified road feature and a fragment of calichecrete was collected from the surface of site 41SP234, the CCC Complex.

\section{${ }^{14}$ C Samples}

Collected ${ }^{14} \mathrm{C}$ samples consisted of charcoal and burned roots. Approximately $8.7 \mathrm{~g}$ of charcoal and/or burned root fragments were collected from all levels of ST 88, excavated approximately $10 \mathrm{~m}$ northwest of the identified Water Tower feature. This may be indicative of a burning event occurring in this location in the past and/or the remains of burned tree and associated root system. An additional $5.7 \mathrm{~g}$ of charcoal were collected from ST 105, excavated in association with the concrete feature identified at 41SP178. The samples collected from ST 105 were from the upper levels (0-10 and 10-20 cmbs), and are possibly the remains of cooking fires from the adjacent campsite. However, previous investigations of this site state the foundation structure was subjected to burning in the past. Collected ${ }^{14} \mathrm{C}$ samples were not subject to radiocarbon or AMS dating.

\section{Glass}

Fifteen whole or fragments of bottle and/or shaped glass were collected during investigations. Two complete bottles were recovered, including a small, amber, patinated medicine bottle recovered from ST 75 within site 41SP228 (Figure 6-1), and a machine-made, Ball art deco bottle collected from the surface of 41SP234 (Figure 6-2).

The small, amber bottle is part of a throat and nasal atomizer, known as the "Holmespray" produced by T. J. Homes Co., Inc., in the 1930s. A review of United States patents indicated that design patent No. 92148 (embossed on the bottom of the amber bottle), was applied for by a Stanley J. McGiveran, of Toledo, Ohio, assignor to the Owens-Illinois Glass Company of Toledo, 


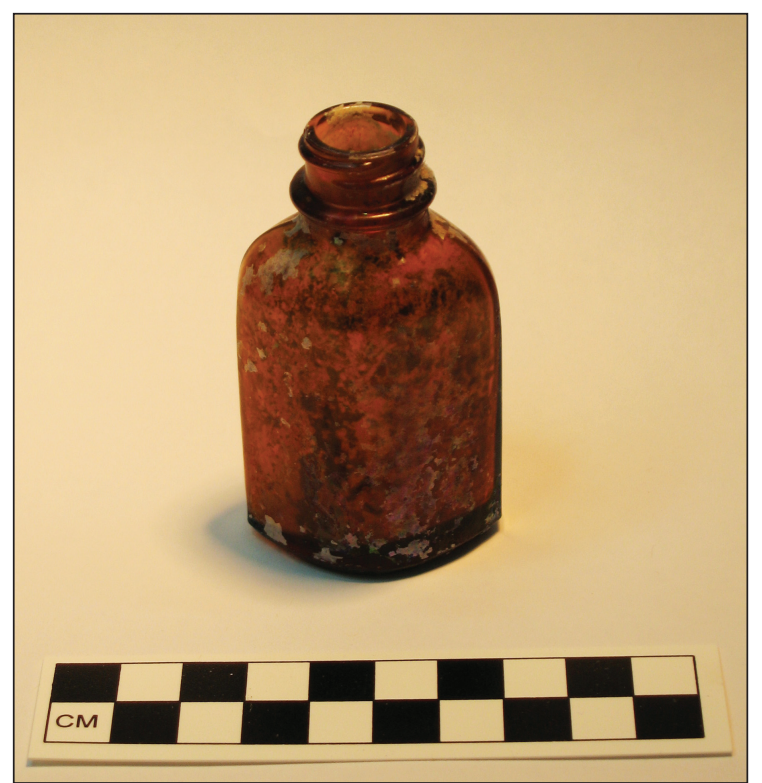

Figure 6-1. Amber atomizer bottle recovered from ST 75, 41SP228.

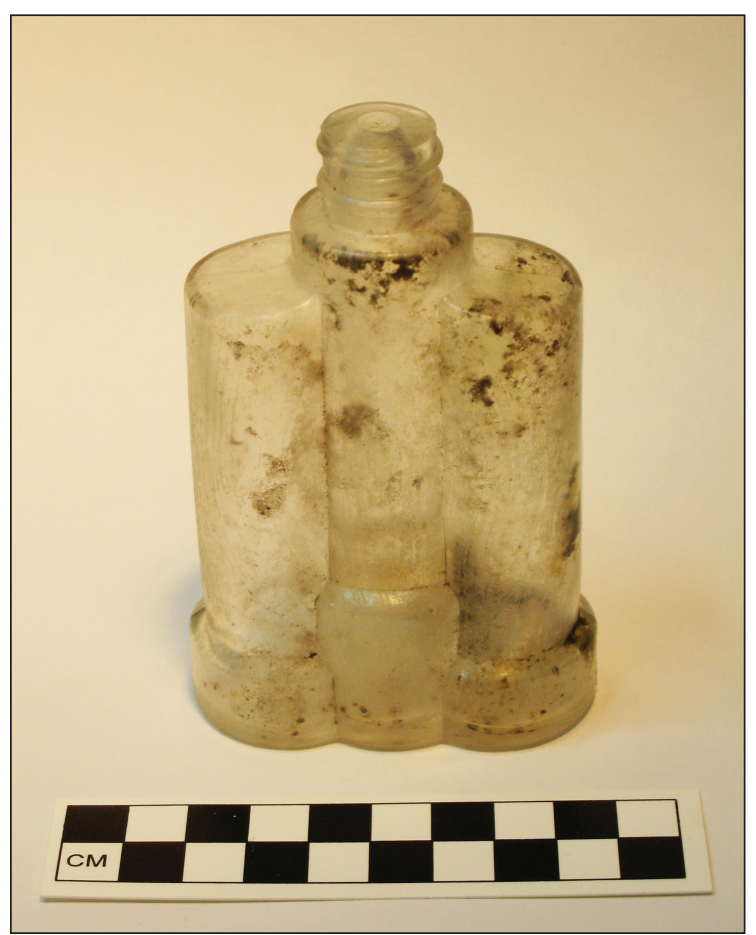

Figure 6-2. Clear art deco bottle recovered from surface, 41SP234.

Ohio, on March 16, 1933. A sketch attached to the design patent application matches the bottle recovered from ST 75 (United States Patent and Trademark Office 2010).
The recovered art deco style bottle contains a script "Ball" maker's mark on the bottom. The Ball Bros. Manufacturing Company, also known as the Ball Bros. Glass Company and after 1969 as the Ball Corporation, was headquartered in Muncie, Indiana, between 1888 and 1996. Originally located in Buffalo, NY (1880-1888), this company relocated to Muncie in 1888 as a result of the natural gas boom in the late 1880s. Best known for its fruit jar manufacturing, Ball also made a variety of other glass items for the packaging industry. The majority of glass containers manufactured by Ball carry the name "Ball" embossed in cursive script either on the side or bottom of the container, although some fruit jars made during certain periods of time also had the name in simple, block letters. The script "Ball" was discontinued in 1988 as a result of their merger with Indianhead Container Corporation, resulting in the company name change to BallInCon Glass Packaging Corp (Toulose 1971). As the collected bottle has a script "Ball" maker's mark, it is most likely manufactured prior to 1988. Its art deco style originated in the 1920s and continued through World War II, suggesting an early to mid-twentieth-century manufacturing date. This is also supported by presences of machine-made molds and the finished lip with screw threads on the bottle.

The remaining shaped glass fragments were collected from ST 87, excavated approximately $8 \mathrm{~m}$ southwest of the identified Water Tower feature, and from ST 104 and ST 105, excavated adjacent to the concrete foundation identified at 41SP178. The fragments collected from the Water Tower feature area included two clear glass fragments and four clear fragments displaying patination, while those collected from 41SP178 consist of both clear (four fragments) and amber (three fragments) glass fragments also containing patintion. Patination is a process of weathering resulting in a decomposition of the glass surface. 
Some glass types are more prone to patination than others, and some environments produce patination more readily than others. The presence or absence of patination does not imply anything about the age of the glass. The process is also known as staining, opalization, opalescence, iridescence, or devitrificaiton (Dumbrell 1983; Kendrick 1963; Tooley 1953).

\section{Metal}

Collected metal artifacts consisted of round wire nails, with the exception of 35 unidentifiable fragments $(25.5 \mathrm{~g})$ of ferrous metal. All metal artifacts were collected from shovel tests (STs 104, 105, and 106) excavated adjacent to the identified concrete foundation at 41SP178. Wire or round nails are the most common used nail in North America today. These nail types were first manufactured in France between 1830 and 1855 by a semi-automated process. By 1855 , the process became fully automated. While some of these fully automated wire nail production machines were first exported to the United States in 1873 , this nail type did not become popular in the US until the late 1880s (Sutton and Askush 1996).

\section{Shell}

Collected shell artifacts consisted of the snail shell of identifiable (Rabdotus sp., Helicina sp.) and unknown species. In all, 104 snail shells (73.9 g) were collected during investigations. Shell artifacts were examined for cultural modification, but none was noted. No dense concentrations of snail shell deposits were noted during field excavations. While it has been argued (Malof 2000) that an analysis of snail shells will provide data useful for dating methods, climate and environmental reconstruction, and aboriginal subsistence, further analysis of the snail shell collected during this project was not conducted.

\section{Lithics}

In all, 158 pieces $(581.9 \mathrm{~g})$ of lithic material were collected during investigations. These materials were further divided into debitage, cores, tools, and other. Lithic artifacts recovered during investigations were assessed based on the following definitions and attributes:

Cores-Cores are defined as chert nodules that possess faceted platforms from which flakes have been removed. Tested cores are chert nodules with a single flake removed from an unprepared cortical platform at one or more location on the chert nodule.

Debitage/Flakes - The term debitage is used to refer to lithic by-products of core and tool production such as flakes and angular debris (Crabtree 1972). Flakes are pieces of lithic material that have been removed from a core or tool through percussion or pressure. Debitage is divided into flakes and flake fragments. Flakes (proximal and complete), consist of all flake debitage with a discernable striking platform or notable point of applied pressure. Flake fragments (incomplete and/or distal flakes) include flake debitage that does not display a recognizable striking platform (Crabtree 1972). Exterior flakes (or cortical) are flakes with exterior cortex resulting from initial tool reduction and primary trimming stages of tool manufacturing. Interior flakes lack cortex and are primarily produced during the secondary finishing stage of lithic tool production (Collins 1998). Non-flake debris lack definable flake characteristics such as a bulb of percussion and platform.

Tools-Lithic tools are chipped stone artifacts that have been intentionally modified or modified by use. These may be modified bifaces, unifaces, flakes, or cores (Andrefsky 1998). Projectile points are modified bifacial 
tools. Scrapers are specialized forms of unifaces that possess secondary retouched edges, resulting in edges shaped to a $60-80$ percent angle (Vierra 1998:119). Untilized flake tools are distinguishable by the presence of one or more edge of a lithic flake that has been modified either through intentional retouching or through the result of use (Andrefsky 1998:79).

Other-This category contains lithic material that cannot be classified into the above-presented categories. The majority of this classification contains non-flake debris. Non-flake debris is characterized by a lack of both a ventral and dorsal side, and it lacks a visible striking platform and/ or bulb of percussion (Andrefsky 1998:81). Nonflack debris is often referred to as angular shatter (Andrefsky 1998:82). It is difficult to determine if these lithic artifact types are the result of cultural modification or natural processes without taking into consideration the context from which the materials were recovered.

\section{Lithic Artifact Descriptions by Provenience}

Nine pieces of lithic materials were collected from shovel tests not associated with known or recently identified archaeological sites. These consisted of one tested core (ST 66), three chert flakes (ST 05, ST 09, ST 70), and five pieces of non-flake debris. The culturally modified lithic materials (tested core and chert flakes) were isolated occurrences and were not found in association with other cultural deposits.

\section{SP178}

Twenty-one pieces (23.9 g) of non-flake debris were collected from shovel tests (ST 104 and ST 105) excavated adjacent to the identified concrete foundation. Based on their context (found in association with a historic/modern concrete feature), and because they lack characteristics indicating that they were culturally modified, it is assumed that these lithic materials are representative of chert road base once present in this location.

\section{SP202}

During reinvestigations of 41SP202, five pieces $(26.8 \mathrm{~g})$ of lithic material were collected from the site surface and consisted of one chert flake and four lithic tools. Lithic tools were further divided into scapers $(n=3$; see Figures 5-14, 5-16, and Figure 5-17) and utilized flake $(n=1$; see Figure 5-15). No lithic materials were recovered from subsurface contexts.

\section{SP228}

Ten lithic pieces (45.9 g) were collected during revisit investigations of 41SP228. One tool (scraper; see Figure 5-23) and one large flake were collected from the surface. Two lithic debitage flakes, three pieces of non-flake debris, and one burned limestone fragment were collected from ST 75 between 10 and $50 \mathrm{cmbs}$. This shovel test was excavated in an area of dense concentration of surface lithic artifacts. Two riverworn pebbles were collected from ST 77 excavated at the far northeastern edge of 41SP228. The low quantities of lithic material collected from subsurface investigations suggest that cultural deposits in this area are shallow and may be subject to erosion.

\section{SP234}

Two pieces of lithic material (one lithic core and one chert flake), were collected from ST 99, which was excavated in association with 41SP234. ST 99 was excavated in a flat, cleared area, approximately $20 \mathrm{~m}$ southwest of the Refectory Building adjacent to the site boundary of 41SP227. The recovery of these types of prehistoric lithic artifacts from this location may be the result of the location of the shovel tests 
next to the site boundary of 41SP227, a probable Late Archaic lithic procurement site and open campsite.

\section{SP235}

In total, 29 pieces $(222.5 \mathrm{~g})$ of lithic material were collected during investigations of 41SP235. Lithic material was further classified into debitage $(n=24)$, cores $(n=3)$, and other (non-flake debris, $\mathrm{n}=1$; riverworn chert shatter, $\mathrm{n}=1)$. All lithic material, with the exception of one tested core, was collected from subsurface contexts. The majority of lithic material (68 percent) was recovered from depths between 0 and $10 \mathrm{cmbs}$. Fourteen percent of the total recovered lithic material was at 10-20 cmbs and 20-30 cmbs. One flake was recovered from a depth of $50 \mathrm{cmbs}$. These data indicate that the cultural deposits in this area are also shallow and may be subject to erosion.

Site 41SP235 is located approximately 380 $\mathrm{m}$ northeast of 41SP227, a Late Archaic lithic procurement site and possible open campsite located atop a gravel-capped point. The lithic material recovered from site 41SP235, therefore, may be the result of early stage lithic reduction processes of cobbles and gravels removed from site 41SP227. With this in mind, the collected debitage flakes were then further delineated into flakes with cortex $(n=11)$ and flakes without cortex $(n=13)$. Flakes with exterior cortex are believed to result from the initial tool reduction and primary trimming stages of tool manufacturing. Only 45 percent of the collected debitage displayed cortex, while 54 percent present was without cortex. This somewhat even division of flakes with and without cortex does not clearly indicate if this deposit is the result of early-stage lithic reduction process. In fact, it has not been clearly demonstrated in the literature that flakes with more cortex are removed earlier in the reduction process than flakes with less to no cortex (Andresfky 1998:112; Mauldin and Amick 1989; Odell 1988). However, the location of this deposit in somewhat close association with a known outcrop of siliceous/cherty gravels and tested cobbles suggests some kind of relationship. The recovery of three cores (two tested cobbles and one core fragment) from this location further suggests some type of primary reduction process did occur in this location. This is additionally supported by the absence of recovered lithic tools, which may indicate a location of end-stage lithic processing.

\section{Water Tower}

In total, 82 pieces of lithic material were collected during excavations associated with the identified possible CCC Water Tower feature. Sixty-four of these pieces consisted of caliche gravels, while the remaining 18 pieces consisted of chert pebble gravels. During a visual inspection of the area surrounding the water tower, a pile of chert stone road base was encountered (see Figure 5-44). The recovered lithic materials, therefore, appear to be remains of a road base that must have been present in this location at one time. 


\section{Chapter 7}

\section{Conclusions ANd Recommendations}

CAS conducted a cultural resources inventory at the Lake Corpus Christi State Park, San Patricio County, Texas. The inventory was conducted on behalf of the TPWD under Texas Antiquities Permit 5652. In all, 368 acres of Lake Corpus Christi State Park were subject to cultural resources investigations. CAS archaeologists revisited and reassessed five previously identified archaeological sites (41SP116, 41SP178, 41SP202, 41SP227, and 41SP228) and recorded and assessed two new sites (41SP234 and 41SP235) and three
CCC-era features (culvert, water tower, and road). This inventory identified and evaluated cultural resources to determine eligibility for SAL designation and NRHP nomination. In addition, each identified and revisited site was given an assessment of the relative management priority on a scale from 1 (highest) to 4 (lowest). Sites were also given specific recommendations for management regardless of management priority (Table 7-1).

Table 7-1. Site Assessment and Recommendations.

\begin{tabular}{cccccc}
\hline Site No./Name & $\begin{array}{c}\text { Relative } \\
\text { Management } \\
\text { Priority }\end{array}$ & $\begin{array}{c}\text { Recommended } \\
\text { Management }\end{array}$ & $\begin{array}{c}\text { Research } \\
\text { Value }\end{array}$ & $\begin{array}{c}\text { SAL } \\
\text { Eligible }\end{array}$ & $\begin{array}{c}\text { NRHP } \\
\text { Eligible }\end{array}$ \\
41SP116 & 4 & No Further Work & None & No & No \\
41SP178 & 3 & Archival Research & Good & Unknown & Unknown \\
41SP227 & 4 & No Further Work & None & No & No \\
41SP228 & 2 & No Further Work & Minimal & Yes & No \\
41SP234 & 2 & Additional Investigations & Good & Yes & Unknown \\
41SP235 & 2 & Additional Investigations & Good & Yes & Unknown \\
CCC Culvert & 4 & No Further Work & None & No & No \\
CCC Water Tower & 3 & No Further Work & Minimal & Unknown & Unknown \\
CCC Road & 3 & No Further Work & Minimal & Unknown & Unknown \\
\hline
\end{tabular}




\section{Summary}

\section{SP116}

Lukowski (1984) orignially described 41SP116 as a light lithic scatter with modern/ historic remains of a fishing camp. During his 1985 investigations, Ralph (1997) recovered a Tortugas projectile point from the surface that dated the prehistoric componenet of the site to the Middle Archaic (2500 BC-400 BC). Ralph (1997) concluded that the fishing camp remains were too recent to be a by-product of $\mathrm{CCC}$ construction and most likely postdated WWII. Ralph (1997) stated that the area was used as a park dump and has been bulldozer-pushed and burned repeatedly in the past.

CAS's reassessment of this site included a review of previous investigations and additional field investigations. A 1933 CCC master plan map indicates that the area of site 41SP116 was within the boundaries of the CCC park, but no structures other than a planned road are discernable (see Appendix D, Figure D-4). Only one piece of lithic debitage was identified on the surface during CAS investigations. CAS excavated four shovel tests within the site's boundaries, but no subsurface cultural material was encountered.

Based on the findings of current field investigations and a review of previous investigations and CCC-era documents, archaeologists from CAS have concluded that site 41 SP116 should be reclassified as a multiplecomponent site that contains both historic and prehistoric components. While previous investigations dated the historic component of the site to post-WWII, the identification of a wind mill water pump with a patent date of 1933 suggests that the historic component may either predate or be contemporaneous with CCC-era construction in the park. CAS archaeologists do, however, concur with the statement that the area was not modified by $\mathrm{CCC}$, as no CCC-era features were noted during field investigations.

Due to the lack of subsurface cultural deposits and the ephemeral nature of the lithic scatter, the research value of the prehistoric component is minimal (see Table 7-1). The use of this area as a park dump and the resulting bulldozing and burning have greatly impacted and most likely destroyed any possible significant cultural remains. Therefore, the site is recommended as not eligible for SAL designation or or for nomination to the NRHP based on the lack of site integrity, significance, and its ability to provide new/unique information. Site 41SP116 is classified as a Level 4 site (Low Management Priority; see Table 7-1), and no further management work is recommended.

\section{SP178}

The "Farm House" site was identified by TPWD archaeologists in 1991 and consisted of the remains of what were believed to be foundations of a domestic structure. While historic debris (brick, glass, and ceramic sherds) was recovered, no temporally diagnostic artifacts were encountered. The site was classified as a “1920s Farm House," based on heresay about a similar-type structure that once stood in the area, but whose whereabouts are now unknown.

During the current investigations, shovel tests excavated next to the foundation recovered brick, glass, gravels, nails, and charcoal. A visual inspection of the surrounding surface identified a piece of metal and associated cement block 75 $m$ to the southwest of the exposed foundation. As no current boundaries of the site existed, a site boundary was drafted that included the metal and cement block and the partially exposed cement foundation. 
Archival research uncovered a CCC sketch map that suggests a $\mathrm{CCC}$ structure may have once been located in the area of the exposed foundation (see Figure D-2, Appendix D). However, due to the poor quality of the CCC sketch, CAS archaeologists are unable to definitively conclude that a CCC structure once stood in this place, but believe that a strong possibility exists that the "Farm House" foundation may be a CCC-era structure.

CAS archaeologists concur with the designation of the site as an early twentiethcentury historic site. However, the designation of the site as a "Farm House" is questionable due to the lack of supporting documentation and the the speculation generated by the $\mathrm{CCC}$ sketch map. Thus, CAS recommends additional archival research to determine the nature and prior use of the partially exposed foundation and surrounding area, as it is possible that it may be a CCC-era feature. The eligibility status of the site is therefore unknown at this time, pending additional archival research. The site may be eligible for SAL designation and/or nomination to the NRHP if it can be shown that the site is indeed a $\mathrm{CCC}$-era feature of significance. If the foundation is a CCC-era feature, it will provide additional information on the distribution and construction of facilities at the park during this time. Site $41 \mathrm{SP} 178$ is classified as a Level 3 Management Priority (Medium to Low Management Priority; see Table 7-1). CAS recommends that this area be avoided until the issue concerning the nature and prior function of the foundation and surrounding area can be resolved.

\section{SP202}

Site 41SP202 was identified during an archaeological survey of a 50 -acre addition to the park in 2002, and was described as a large lithic scatter located in a plowed agricultural field (Marek 2002). During that survey, lithic material was recovered from the site's surface down to $20 \mathrm{cmbs}$. Artifcacts included numerous flakes (some heat treated), cores, and two biface fragments (Marek 2002). Marek suggested that the site extended to the south into a wooded section, although she did not examine that area. Therefore, the southern boundary of the site was not fully determined (Marek 2002).

CAS confirmed the presence of the light lithic scatter within the previously determined site boundaries. Four lithic tools (see Figures 5-14 through 5-17) were noted and collected from surface context. A single shovel test was excavated in the location of two of the collected tools (Scraper A and Utilized Flake B), but no subsurface cultural deposits were encountered. A visual inspection of the surface of the wooded area to the south of the site did not identify any cultural deposits on the surface. Five shovel tests (STs 107, 108, 109, 123, and 125) were excavated within this wooded area, but no subsurface cultural deposits were encountered.

CAS archaeologists concur with the designation of the site as a lithic scatter of indeterminate age. Due to the negative shovel tests in the wooded area to the south of the existing site boundary, it is believed that the site does not extend further into this region. Therefore, site boundaries remain as they were drafted by the previous investigation.

The research value of this site is low due to the lack of subsurface cultural deposits and the ephemeral nature of the surface lithic scatter compromised by repeated plowing of the area (see Table 7-1). The site is recommended as not eligible for SAL designation and/or NRHP nomination based on the lack of site integrity, significance, and its inability to provide new/ unique information. Site 41SP202 is classified as a Level 4 site (Low Management Priority; see 
Table 7-1), and no further management work is recommended.

\section{SP227}

Site 41SP227 was recorded by Ringstaff (2007a) as a prehistoric lithic procurement site of indeterminate age and possible open campsite. However, an Ensor point was recovered during Ringstaff's investigations that suggested a Late Archaic (400 BC-AD 800) age. Additional artifacts noted during the his investigations included lithic debitage, biface fragments, and tested cobbles. Ringstaff concluded that the site was primarily used as a lithic procurement site (Ringstaff 2007a).

CAS archaeologists traversed the peninsula, visually inspecting the surface of the site. The site is bisected by a heavily utilized trail that runs north to south from the Refectory building to the shore line. While siliceous/cherty gravels, tested cobbles, and lithic debitage were observed on visible surface areas, no diagnostic artifacts were observed or collected. No shovel tests were excavated in this area due to exposed bedrock and the lack of soil deposition. An area of possible bedrock grinding mortars was identified, but determined to be solution cavities upon closer inspection.

CAS concurs with the designation of this site as a lithic procurement site and possible open campsite. However, the inclusion of a Late Archaic date should be added to this site based on the recovery of an Ensor point during Ringstaffs investigations. The current boundary of the site was also expanded to encompass the entire peninsula, conforming to the area of surface artifact distribution noted during the CAS's investigation.

No further investigations of this site are recommended. The site is recommended as not eligible for NRHP nomination due to its lack of integrity and inability to provide new and unique information. However, the site does appear to be endangered by the heavily traversed trail bisecting the site and may warrant the designation of this site as an SAL based on Criterion 5:

the high likelihood that vandalism and relic collecting has occurred or could occur, and official landmark designation is needed to insure maximum legal protection, or alternatively further investigations are needed to mitigate the effects of vandalism and relic collecting when the site cannot be protected.

Based on these conclusions, site 41SP227 is given a Medium to Low Management Priority (Level 3; see Table 7-1).

\section{SP228}

A multiple-component prehistoric lithic scatter/open camp site and scatter of historicera artifacts was recorded by Ringstaff in 2007 (2007b). Ringstaff noted an area of dense lithic debitage in the southern portion of the site during his investigations. Recovered prehistoric artifacts included, chert cores, biface fragments, lithic debitage, and a possible Martindale point suggesting an Early Archaic (6000-2500 BC) age. Historic artifacts consisted of solarized glass shards and whiteware ceramic sherds.

CAS archaeologists visually inspected the surface area of the south camping loop, the roads surrounding the camping area, the wooded area to the north and northwest, and the areas just outside the site boundaries. Three shovel tests (ST 75, ST 76, and ST 77) were also excavated in the area. Several pieces of chert debitage were observed on the surface of the cleared camping area, appearing most dense along the top of the ridge extending from the northeast to 
the southwest through the camping loop area. Several lithics were recovered from ST 75 in this area. A cut bank was noted during examination of the wooded area to the northwest of the site, and two profiles were recorded. No cultural materials were eroding out of the cut bank. While no prehistoric artifacts were noted during examination of the wooded area, three cement blocks (one with an iron protrusion, see Figure 5-22) were observed and recorded in addition to various non-diagnostic historic/modern debris. Site boundaries were redrafted to include the profiled cut banks and the observed historic/ modern debris.

Archaeologists from CAS concur with the designation of this as a multiple-component site (historic and prehistoric). The inclusion of an Early Archaic date should be added to this site based on the recovery in 2007 of the possible Martindale point. Further investigations of this site are recommended to determine the nature of these deposits and potential eligibility for nomination to the NRHP. The site may be eligible for nomination recommendation if further testing investigations indicate it possesses integrity and the potential to provide important information on prehistory, specifically, Early Archaic occupation and use under NRHP Criterion D. Additionally, the nature (high visibility of lithic materials on the ground surface) and location (within the cleared, central area adjacent to the restroom facilities of the heavily used south camping loop) of this site compel the recommendation for SAL status base on SAL Criterion 5:

the high likelihood that vandalism and relic collecting has occurred or could occur, and official landmark designation is needed to insure maximum legal protection, or alternatively further investigations are needed to mitigate the effects of vandalism and relic collecting when the site cannot be protected.
Based on the above observations, site 41SP228 has been given a Management Priority ranking of 2 (see Table 7-1).

\section{SP234}

CAS revisited the Refectory Complex and recorded, photographed, and mapped the features and structures in the area (Refectory building, Grand Stair Case, and Pump House). Three shovel tests were excavated on the grounds of the Refectory Building: ST 98, ST 99, and ST 100. An exhausted core and a large lithic flake were recovered from ST 99, which was excavated adjacent to the site boundary of 41SP227. A complete, small, art deco-style bottle (see Figure 6-2) was recovered from the surface. A site boundary for the Refectory Complex was drafted to include the Refectory Building, the Grand Staircase, the Pump House, and the excavated shovel tests. The site was classified as a multiplecomponent site (historic and prehistoric). A TexSite form (Appendix C) was completed for this site complex and a site designation number, 41SP234, was given.

Site 41SP234 may be eligible for nomination to the NRHP under Criteria A, C, and D, contingent on results of further testing investigations. The buildings and structures of site 41SP234 were constructed between 1934 and 1936 by CCC Company 886 during the Depression era (TPWD 2010b). The CCC was established by President Roosevelt in 1933 to protect land resources and provide employment opportunities for the jobless. This program was utilized by the State of Texas to develop the core of its parks system (TPWD 2010b). Therefore, this site and in particular these structures represent an important period and event not only in the history of the United States, but in the history of Texas and the development of its park system. 
The construction and craftsmanship of the buildings and structures that are a part of 41SP234 are distinctive, displaying detailed characteristics of CCC-era building techniques. The primary building material is "calichecrete" cast blocks. These blocks were manufactured on-site and consist of 15 percent concrete and 85 percent locally quarried caliche. The blocks were cast in various sizes, individually tooled to give them the appearance of cut stone, and laid in a random-ashlar pattern (Quimby McCoy 2008; Steely 1999)). Additional character-defining features include arched entries, short buttresses flanking some of the arches, exposed timber trusses, and a wood shingle roof with a clay tile ridge on the Refectory Building (Quimby McCoy 2008).

CAS recommends further testing investigations to gather additional information on both the prehistoric and historic components of this site. A more thorough historic and archival study of the site will provide additional information regarding CCC activities in Texas during the Depression and on the early use of the site as a recreational component of Lake Corpus Christi State Park.

The site is also recommended for SAL designation based on Criterion 5. This site and its associate structures and features appeared to be a popular visitor destination; several park guests were encountered during the cultural resources inventory at this location. Two of the features within this site, the Grand Stair Case and the Pump House, are in immediate need of assessment and stabilization. Erosion and landform weakening has compromised the foundation of the Pump House and the Grand Stair Case. This, coupled with the visitor use and the potential for vandalism, lends itself to concerns about site preservation. Based on these observations, site $41 \mathrm{SP} 234$ has been given a Management Priority ranking of 2 (see Table 7-1).

\section{SP235}

CAS archaeologists recorded a lithic scatter in a densely wooded area along the southern park road. Fourteen shovel tests (eight of which contained prehistoric lithic materials) were excavated in the area and were used to define the site. The site measures $23 \times 10 \mathrm{~m}\left(193 \mathrm{~m}^{2}\right)$. The site was classified as a prehistoric lithic scatter of unknown age, and a TexSite form (Appendix C) was completed. A trinomial, 41SP235, was then assigned.

No further research is recommended for this site (see Table 7-1). The research value of this site is low due to a lack of diagnotic cultural deposits and identifiable cultural features. CAS recommends that the site is not eligible for nomination to the NRHP or for designation as an SAL based on the lack of site significance and its inability to provide new/unique information. Site 41SP235, therefore, is classified as a Level 4 site (Low Management Priority; see Table 7-1), and no further management work is recommended.

\section{Culvert}

During investigations, what appears to be a CCC-constructed culvert was encountered along Park Road 25 (see Figures 5-35 through 5-39). This culvert is composed of materials similar to other CCC structures located within the park. The northern portion of the culvert appears to be in good condition, while the southern side appears to have suffered some damage, and attempts at stabilizing the structure and adjacent bank with concrete were noted. The culvert was not listed by Quimby and McCoy assessment; however, the feature is clearly indicated on a CCC Master Plan Map of the park (see Figure D-4, Appendix D). 
The culvert is an additional example of the type of cast calichecrete block construction employed by the CCC during the depression era. Additional investigations of this culvert are not recommended as this feature type has been previously documented by the Quimby and McCoy assessment (Quimby and McCoy 2008). The NHRP and SAL eligibility status of this feature is currently undetermined. It may qualify under the same criteria as those proposed for the CCC Complex (41SP234) or it may be included as a component/element of NHRP/SAL-eligible CCC-era structures/features located within Lake Corpus Christi State Park. The feature, therefore, has been given a Medium to Low Management Priority (Level 3; see Table 7-1).

\section{Water Tower}

A water tower located approximately $170 \mathrm{~m}$ north of the CCC Refectory Building (see Figure 5-32) was also examined during investigations. As the water tower appeared to be similar in design and construction to the CCC-era concrete water tower identified at the Park Superintendent's Residence (Quimby McCoy 2008:22), it was also classified as a CCC-era building. Glass and road base materials were recovered from the shovel tests excavated adjacent to the water tower. A pump house (see Figure 5-33), and a pile of chert road base (see Figure 5-35) were also noted nearby.

The research potential of this feature is considered to be minimal beyond the inclusion of this feature with other CCC-era features located in Lake Corpus Christi State Park. As with the CCC Culvert, the NHRP and SAL eligibility recommendations of this feature are currently undetermined. It may also qualify under the same criteria as those proposed for the CCC Complex (41SP234) or it may be included as a component/ element of NHRP/SAL-eligible CCC-era structures/features. The water tower, therefore, has been given a Medium to Low Management Priority (Level 3; see Table 7-1).

\section{Road in NW Corner}

The remains of a set of roadways (forming a $\mathrm{Y}$ intersection) were uncovered in the far northwest corner of the park during investigations. Asphalt fragments were recovered from a shovel test (ST 120) excavated adjacent to a portion of this feature. The road segment is not noted on the 1979 quad map of the area and therefore most likely predates the late 1970 s. It may be a possible CCC-era feature and may be evidence of the original park entryway as envisioned by $\mathrm{CCC}$ planners. This determination is inconclusive, as this road segment cannot be clearly discerned on the CCC Master Plan Map of Lake Corpus Christi State Park. Further archival and possible archaeological research is recommended to determine the nature and age of this feature. As with the above-listed possible CCC features, the NHRP and SAL eligibility recommendations of this feature are currently undetermined. It may qualify under the same criteria as those proposed for the CCC Complex (41SP234), or it may be included as a component/element of NHRP/ SAL-eligible CCC-era structures/features located within Lake Corpus Christi State Park. The feature, therefore, has been given a Medium to Low Management Priority (Level 3; see Table 7-1).

\section{Conclusions}

\section{Prehistoric Sites}

Prehistoric sites and/or sites with prehistoric components (41SP116, 41SP227, 41SP228, 41SP234, and 41SP235) identified during cultural resources investigations at Lake Corpus Christi State Park generally consisted of surface or 
shallow subsurface lithic deposits. It is clear from the distribution of surface lithic artifacts and the geological formation of site 41SP227 that this was once a prehistoric lithic procurement site. Sites 41SP116, 41SP202, 41SP228, and 41SP235 may have been prehistoric occupation/ use sites; however, further evidence to support this contention is needed before such a designation can be determined for these sites. The shallow ephemeral nature of the lithic deposits encountered at sites 41SP116, 41SP202, and 41SP235 rule out the need for additional investigations in these locations to determine the nature of these deposits. However, the dense nature and somewhat deeper depositional characteristic of the lithic deposits encountered at 41SP228 suggest that additional investigations at this location may reveal further information on the use of the area in the prehistoric past.

\section{Historic Sites}

Sites and/or site components (41SP116, 41SP178, 41SP228, and 41SP234) identified during cultural resources investigations that can be dated to historic and/or modern periods generally consist of CCC-era features and structures. CCC-era construction within the park has been clearly documented. Lake Corpus Christi State Park Project SP-32 was developed by CCC Company 886 on an initial 288 -acre tract. This tract was leased from the City of Corpus Christi in 1934 for duration of 99 years. "Camp Kleberg" was established on April 27, 1934, by the CCC. CCC-constructed structures and features include a concession building (Refectory Building) designed by architect Olin Boese that was built of cast calichecrete blocks, a dance terrace, a calichecrete stone staircase to the water's edge, roads, bridges, two boathouses, a bathhouse, and a residence (Steely 1999). A nearby dam was constructed concurrently by the city. While documentation on the CCC-era construction activities exists, testing investigations at site
41SP234 are warranted as an aid not only in determining NRHP nomination eligibility, but also to provide additional information regarding CCC activities in Texas during the Depression and the early use of the site as a recreational component of Lake Corpus Christi State Park.

\section{Recommendations}

Cultural resource managers should not consider all areas of the park covered by this survey to be cleared for all future construction. The purpose of these investigations were an identification-level survey, with data collected to be utilized in determining NRHP nomination and SAL listing eligibility and future management practices. Management recommendations and recommendations for further work on each individual site identified and/or revisited are presented in Table 7-1 and discussed in the above section. While several archaeological sites were identified and/or revisited during investigations, TPWD cultural resources managers need to take into account the effects of specific construction and maintenance practices on the sites discussed in this report. More intensive investigations may be needed depending on the impact of park development or maintenance. Many of the identified features and archaeological sites within Lake Corpus Christi State Park are in frequent and direct contact with park visitors. It is important that all park visitors be made aware of the significance of these identified features and archaeological sites in the park, and of the penalties carried for vandalizing them. Archaeological sites 41SP227, 41SP228, and 41SP234 in particular have been recommended for SAL listing based on the high likelihood that vandalism or relic hunting have occurred or are likely to occur at these locations. It is recommended that all sites be monitored at least biennially for evidence of vandalism or damage from park visitation or maintenance activities. 


\section{References Cited}

Andrefsky, William, Jr.

1998 Lithics: Macroscopic Approaches to Analysis. 2nd ed. University of Cambridge Press, Cambridge.

Black, Stephen L.

1989 South Texas Plains. In From the Gulf to the Rio Grande: Human Adaptation in Central, South and Lower Pecos Texas, by T. R. Hester, S. L. Black, D. G. Steele, B. W. Olive, A. A. Fox, K. Reinhard, and L. C. Bement, pp. 39-62. Research Series No. 33. Arkansas Archeological Survey, Fayetteville.

Boes, Thomas C.

1991 Letter dated September 11, 1991, to Mark Denton, Texas Antiquities Committee. Document on File, Cultural Resources Program, Texas Parks and Wildlife, Austin.

Brown, Kenneth L.

1984 An Assessment of the Impact on Archaeological/Historical Resources of a Proposed Oil Well on Camp Karankawa, Lake Corpus Christi State Recreation Area, San Patricio County, Texas (Draft). Document on file, Cultural Resources Program, Texas Parks and Wildlife, Austin.

Collins, Michael B., assembler and editor

1998 Wilson-Leonard: An 11,000-Year Archeological Record in Central Texas. 6 Vols. Studies in Archeology 31, Texas Archeological Research Laboratory, The University of Texas at Austin. Archeology Studies Program Report 10, Texas Department of Transportation, Environmental Affairs Division, Austin.

Crabtree, Don E.

1972 An Introduction to Flintworking. Occasional Papers No. 28. Idaho State University, Pocatello.

Dumbrell, Roger

1983 Understanding Antique Wine Bottles. Antique Collectors Club, printed by Baron Publishing, Suffolk, England.

Guthrie, Keith

2010a Handbook of Texas Online, s.v. "San Patricio County," http://www.tshaonline.org/handbook/ online/articles/SS/hcs4.html (accessed April 14, 2010).

2010b Handbook of Texas Online, s.v. "Mathis, Texas," http://www.tshaonline.org/handbook/online/ articles/MM/hfm3.html (accessed April 14, 2010). 
Hester, T. R.

1975 Evaluation of the Archeological Resources in the Area of the Proposed Prime Project to Modify the Corpus Christi Ship Channel. US Army Corps of Engineers, Galveston District, Galveston, Texas.

Jones, Fred B.

1982 The Flora of the Texas Coastal Bend. Welder Wildlife Foundation, Sinton, Texas.

Kendrick, Grace

1963 The Antique Bottle Collector. Western Printing \& Publishing Co., Sparks, NV.

Lukowski, Paul D.

1984 An Archaeological Survey of a Proposed Well Pad in the Vicinity of Lake Corpus Christi, State Recreation Park, San Patricio County, Texas (Draft). Archaeological Survey Report, No. 134. Center for Archaeological Research, The University of Texas at San Antonio.

Malof, Andrew F.

2000 Texas Snails in Archaeological Context. Electronic document, http://www.dirtbrothers.org/ editorial/malof.htm (accessed November 2010).

Marek, Marianne

2002 Archaeological Survey at Lake Corpus Christi State Park, San Patricio County, Texas. Marianne Marek, Archaeological Consultant, Wallis.

Mercado-Allinger, Patricia A., Nancy A. Kenmotuso, and Timothy K. Pettula (editors)

1996 Archaeology in the Central and Southern Planning Region, Texas: A Planning Document. Office of the State Archeologist, Special Report 35 and the Department of Antiquities Protection, Cultural Resource Management Report 7. Texas Historical Commission, Austin.

Mercado-Allinger, Patricia A., and Robert A. Ricklis

1996 Introduction. Section II: Regional Preservation Plan for Archeological Sites, Southern Coastal Corridor Archeological Region, Central and Southern Planning Region. In Archaeology in the Central and Southern Planning Region, Texas: A Planning Document, edited by Patricia A. Mercado-Allinger, Nancy A. Kenmotuso, and Timothy K. Pettula, pp. 47-76. Office of the State Archeologist, Special Report 35 and the Department of Antiquities Protection, Cultural Resource Management Report 7. Texas Historical Commission, Austin.

Mauldin, Raymond P., and Daniel S. Amick

1989 Comments on Sullivan and Rozen's "Debitage Analysis and Archaeological Interpretation." American Antiquity 54(1):166-168.

Odell, G. H.

1988 Addressing Prehistoric Hunting Practices through Stone Tool Analysis. American Antiquity 90:335-356. 
Quimby McCoy Preservation Architecture, LLP

2008 Inventory and Assessment of Civilian Conservation Corps Structures in Lake Corpus Christi State Park, San Patricio, Jim Wells, and Live Oak Counties, Texas. Texas Parks and Wildlife Department, Infrastructure Division, Austin.

Ralph, Ron

1997 An Inventory of Cultural Resources within the Texas Park System: November 1981 through October 1986. Texas Parks and Wildlife, Austin.

Ringstaff, Christopher

2007a TexSite Site Survey Form. Texas Historical Commission Texas Archeological Sites Atlas, s.v. “41SP227," http://nueces.thc.state.tx.us/ (accessed April 12, 2010).

2007b TexSite Site Survey Form. Texas Historical Commission Texas Archeological Sites Atlas, s.v. “41SP228," http://nueces.thc.state.tx.us/ (accessed April 12, 2010).

Scott, R. F., IV, and D. E. Fox

1981 Excavations at Sites 41LK31/32 and 41LK202 in the Choke Canyon Reservoir, South Texas. Choke Canyon Series 8. Center for Archaeological Research, The University of Texas at San Antonio.

Steely, James Wright

1999 Parks of Texas: Enduring Landscapes of the New Deal. University of Texas Press, Austin.

Sutton, Mark Q., and Brooke S. Arkush

1996 Archaeological Laboratory Methods: An Introduction. Kendall/Hunt Publishing Company, Dubuque, Iowa.

Texas Parks and Wildlife

1995 Archeology Lab Manual. Cultural Resources Program, Texas Parks and Wildlife Department, Austin.

2010 Lake Corpus Christi State Park website, http://www.tpwd.state.tx.us/spdest/findadest/parks/ lake_corpus_christi/\#hist (accessed April 14, 2010).

Tooley, Fay V. (editor)

1953 Handbook of Glass Manufacture: A Book of Reference for the Factory Engineer, Chemist and Plant Executive. Ogden Publishing Company, New York.

Toulouse, Julian Harrison

1971 Bottle Makers and Their Marks. Blackburn Press, New Jersey.

United States Congress

2004 National Register of Historic Places. 36CFR Part 60. 
USDA Natural Resources Conservation Service

2009 Map Unit Description: San Patricio and Aransas Counties, Version 6. Electronic document, http://websoilsurvey.nrcs.usda.gov (accessed April 12, 2010).

US Patent and Trademark Office

2010 US Patent and Trademark Office website, htttp://www.uspto.gov (accessed July 2010).

Vierra, Bradley J., with contributions C. Britt Bousman, John R. Cross, J. Philip Dering, Wulf Gose, Anne A. Fox, Robert G. Howells, Johanna Hunziker, David L. Nickels, Artie L. Metcalf, Barbara A. Meissner, and Lee C. Nordt

1998 41MV120: A Stratified Late Archaic Site in Maverick County, Texas. Archaeological Survey Report No. 251. Center for Archaeological Research, The University of Texas at San Antonio.

Warren, James E.

1984 A Cultural Resources Survey of Four Water Well Drilling Sites at Lake Corpus Christi, Live Oak, San Patricio and Jim Wells Counties, Texas (Draft). Submitted to the City of Corpus Christi, Nueces County, Texas. Document on file, Cultural Resources Program, Texas Parks and Wildlife, Austin. 
Appendix A

LCCSP Archaeological Survey Shovel Test Results 
Center for Archeological Studies
Texas State University - San Marcos

LCCSP Archaeological Survey Shovel Test Results

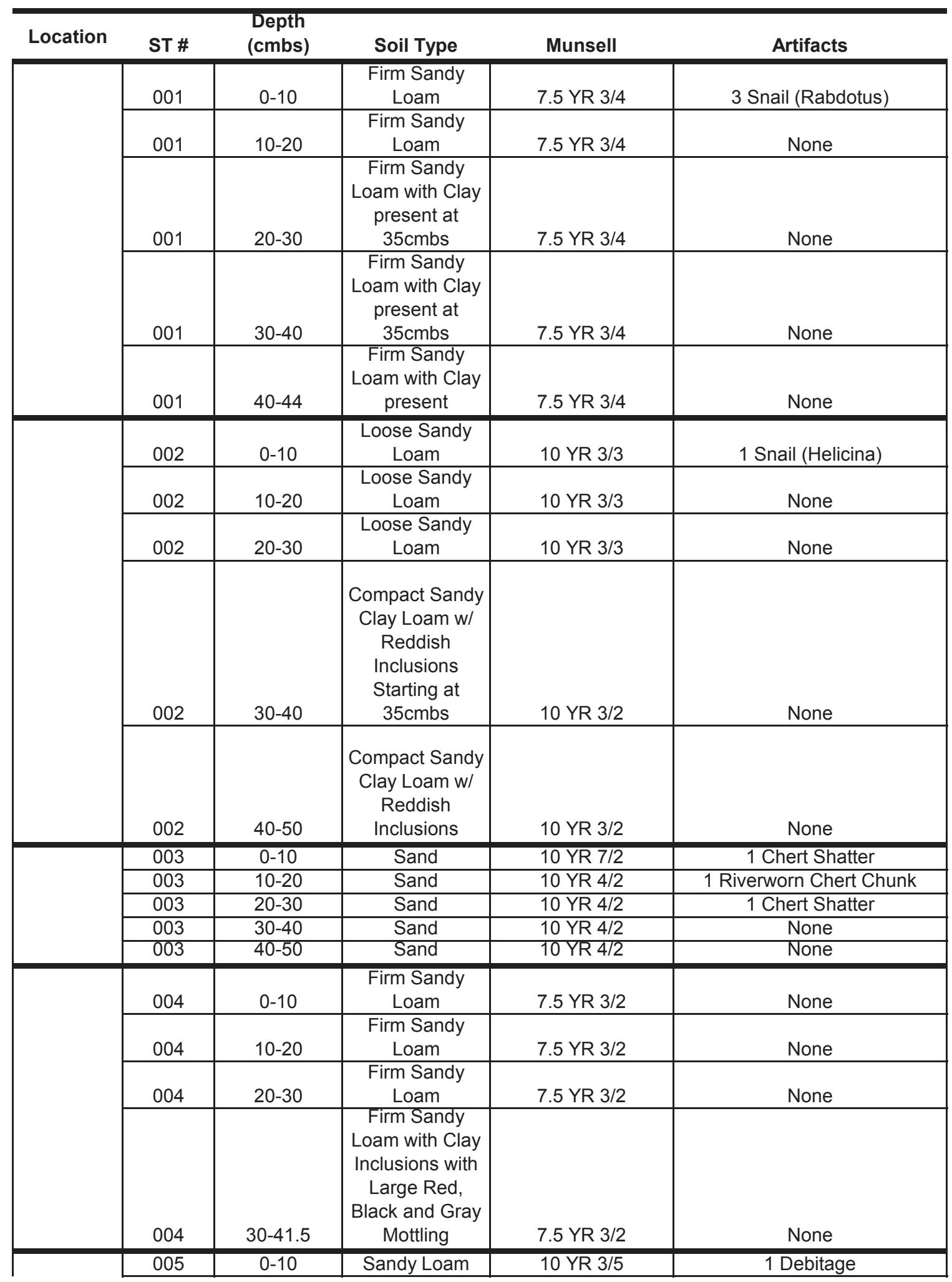




\section{LCCSP Archaeological Survey Shovel Test Results}

\begin{tabular}{|c|c|c|c|c|c|}
\hline Location & ST \# & $\begin{array}{l}\text { Depth } \\
\text { (cmbs) }\end{array}$ & Soil Type & Munsell & Artifacts \\
\hline & 005 & $10-20$ & $\begin{array}{l}\text { Sandy Clay } \\
\text { Loam }\end{array}$ & 10 YR 3/2 & None \\
\hline & 005 & $20-30$ & $\begin{array}{l}\text { Sandy Clay } \\
\text { Loam }\end{array}$ & $10 \mathrm{YR} 3 / 2$ & None \\
\hline & 005 & $30-40$ & $\begin{array}{l}\text { Sandy Clay } \\
\text { Loam }\end{array}$ & 10 YR 3/2 & None \\
\hline & 005 & $40-50$ & $\begin{array}{l}\text { Sandy Clay } \\
\text { Loam }\end{array}$ & 10 YR 3/2 & None \\
\hline & 006 & $0-10$ & Sandy Loam & $10 \mathrm{YR} 6 / 2$ & 1 Snail (Rabdotus) \\
\hline & 006 & $10-20$ & Sandy Loam & 10 YR 6/2 & $\begin{array}{c}2 \text { Snail (1 Rabdotus, } 1 \\
\text { Helicina) }\end{array}$ \\
\hline & 006 & $20-30$ & Sandy Loam & $10 \mathrm{YR} 6 / 2$ & None \\
\hline & 006 & $30-40$ & Sandy Loam & 10 YR $6 / 2$ & None \\
\hline & 006 & $40-50$ & Sandy Loam & $10 \mathrm{YR} 6 / 2$ & None \\
\hline & 007 & $0-10$ & $\begin{array}{l}\text { Sandy Loam, } \\
\text { Few Instances } \\
\text { of Clay but } \\
\text { Dense when } \\
\text { Present } \\
\text { (red/gray } \\
\text { mottling) }\end{array}$ & 7.5 YR 3/4 & None \\
\hline & 007 & $10-20$ & $\begin{array}{l}\text { Sandy Loam, } \\
\text { Few Instances } \\
\text { of Clay but } \\
\text { Dense when } \\
\text { Present } \\
\text { (red/gray } \\
\text { mottling) } \\
\end{array}$ & 7.5 YR 3/4 & None \\
\hline & 007 & $20-30$ & $\begin{array}{c}\text { Sandy Loam, } \\
\text { Clay Becoming } \\
\text { more Dense, } \\
\text { Displaying Red, } \\
\text { Gray and Black } \\
\text { Mottling } \\
\end{array}$ & 7.5 YR 3/4 & None \\
\hline & 007 & $30-40$ & $\begin{array}{l}\text { Sandy Loam, } \\
\text { Clay Becoming } \\
\text { more Dense, } \\
\text { Displaying Red, } \\
\text { Gray and Black } \\
\text { Mottling }\end{array}$ & 7.5 YR $3 / 4$ & None \\
\hline & 008 & $0-10$ & Silty Loam & 7.5 YR 3/2 & 1 Snail (Rabdotus) \\
\hline & 008 & $10-20$ & $\begin{array}{c}\text { Silty Loam, Clay } \\
\text { Inclusions begin } \\
\text { at } 17 \mathrm{cmbs}\end{array}$ & 7.5 YR 3/2 & None \\
\hline & 008 & $20-30$ & $\begin{array}{c}\text { Silty Loam, } \\
\text { More Clay at } \\
\text { this Depth }\end{array}$ & 7.5 YR 4/4 & None \\
\hline & 008 & $30-40$ & $\begin{array}{l}\text { Silty Loam, } \\
\text { More Clay at } \\
\text { this Depth }\end{array}$ & 7.5 YR 4/4 & None \\
\hline & 008 & $40-42$ & $\begin{array}{l}\text { Silty Loam, } \\
\text { More Clay at } \\
\text { this Depth }\end{array}$ & 7.5 YR 4/4 & None \\
\hline
\end{tabular}




\section{LCCSP Archaeological Survey Shovel Test Results}

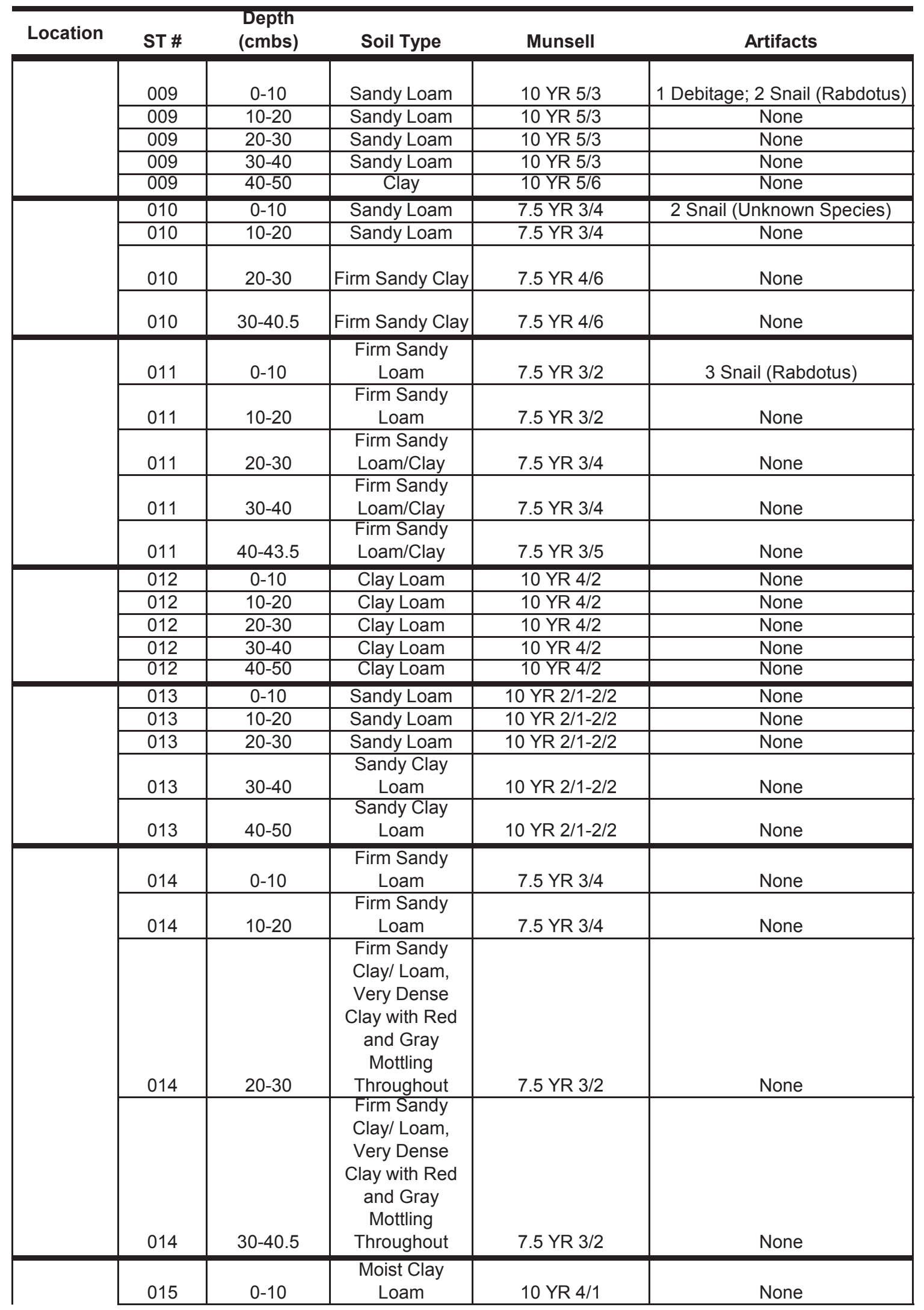




\section{LCCSP Archaeological Survey Shovel Test Results}

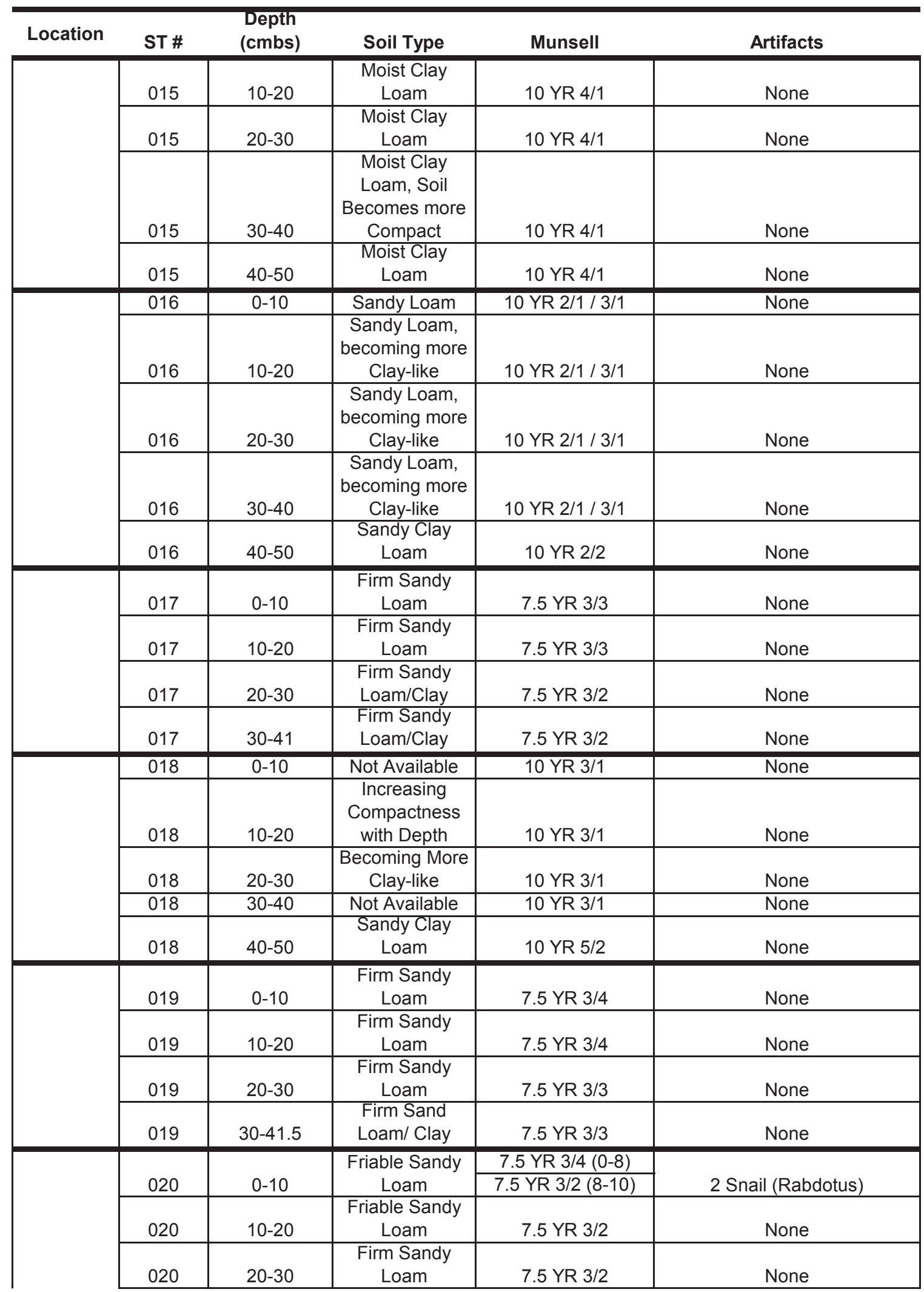




\section{LCCSP Archaeological Survey Shovel Test Results}

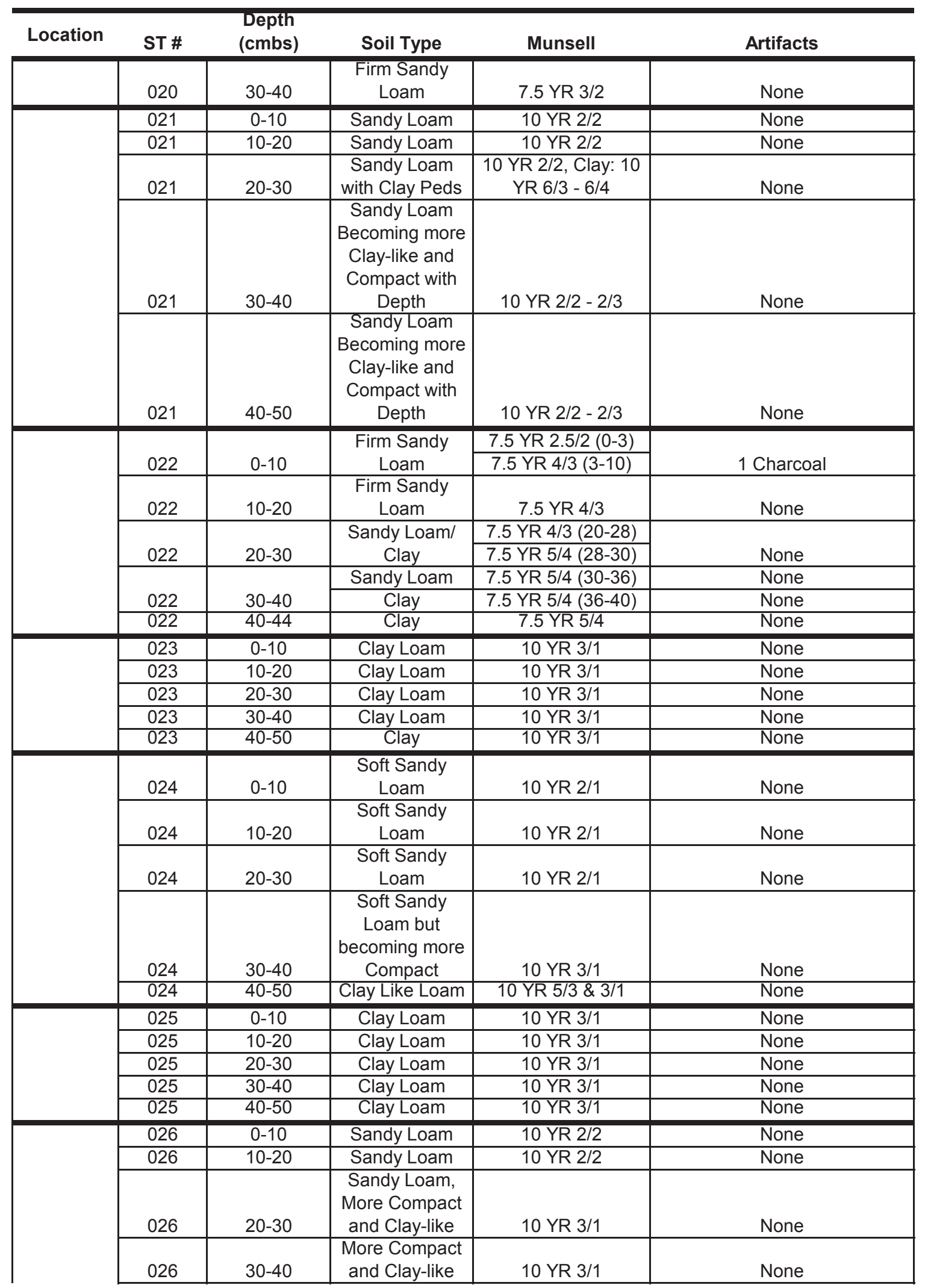




\section{LCCSP Archaeological Survey Shovel Test Results}

\begin{tabular}{|c|c|c|c|c|c|}
\hline \multirow[t]{2}{*}{ Location } & ST \# & $\begin{array}{l}\text { Depth } \\
\text { (cmbs) }\end{array}$ & Soil Type & Munsell & Artifacts \\
\hline & 026 & $40-50$ & $\begin{array}{l}\text { More Compact } \\
\text { and Clay-like }\end{array}$ & $\begin{array}{c}10 \mathrm{YR} 3 / 1 \& 10 \mathrm{YR} \\
5 / 2\end{array}$ & None \\
\hline & 027 & $0-10$ & Not Available & $\begin{array}{c}\text { Soil: } 7.5 \text { YR } 3 / 3 \\
\text { Mottles: } 7.5 \text { YR 5/6 }\end{array}$ & 1 Snail (Rabdotus) \\
\hline & 027 & $10-20$ & Not Available & $\begin{array}{c}\text { Soil: } 7.5 \text { YR } 3 / 3 \\
\text { Mottles: } 7.5 \text { YR 5/6 }\end{array}$ & None \\
\hline & 027 & $20-30$ & Not Available & $\begin{array}{c}\text { Soil: } 7.5 \text { YR 4/1 } \\
\text { Mottles: } 7.5 \text { YR 6/1 }\end{array}$ & 1 Snail (Rabdotus) \\
\hline & 027 & $30-41$ & Not Available & $\begin{array}{c}\text { Soil: } 7.5 \text { YR 4/1 } \\
\text { Mottles: } 7.5 \text { YR 6/1 }\end{array}$ & None \\
\hline & 028 & $0-10$ & $\begin{array}{l}\text { Loose Sandy } \\
\text { Loam }\end{array}$ & 7.5 YR 5/2 & 5 Snail (Rabdotus) \\
\hline & 028 & $10-20$ & $\begin{array}{l}\text { Loose Sandy } \\
\text { Loam }\end{array}$ & 7.5 YR 5/2 & None \\
\hline & 028 & $20-30$ & $\begin{array}{c}\text { Firm Sandy } \\
\text { Loam }\end{array}$ & 7.5 YR 6/3 & None \\
\hline & 028 & $30-41$ & $\begin{array}{l}\text { Firm Sandy } \\
\text { Loam }\end{array}$ & 7.5 YR 6/3 & None \\
\hline & 029 & $0-10$ & $\begin{array}{c}\text { Moist Clay } \\
\text { Loam }\end{array}$ & 10 YR 3/1 & None \\
\hline & 029 & $10-20$ & $\begin{array}{l}\text { Moist Clay } \\
\text { Loam }\end{array}$ & 10 YR 3/1 & None \\
\hline & 029 & $20-30$ & $\begin{array}{l}\text { Moist Clay } \\
\text { Loam }\end{array}$ & 10 YR 3/1 & None \\
\hline & 029 & $30-40$ & $\begin{array}{c}\text { Moist Clay } \\
\text { Loam }\end{array}$ & 10 YR 3/1 & None \\
\hline & 030 & $0-10$ & $\begin{array}{l}\text { Organic Sandy } \\
\text { Loam }\end{array}$ & 10 YR 2/1 & None \\
\hline & 030 & $10-20$ & $\begin{array}{c}\text { Organic Sandy } \\
\text { Loam }\end{array}$ & 10 YR 2/1 & None \\
\hline & 030 & $20-30$ & $\begin{array}{c}\text { Organic Sandy } \\
\text { Loam }\end{array}$ & 10 YR 2/1 & None \\
\hline & 030 & $30-40$ & Sandy Loam & $10 \mathrm{YR} 3 / 2$ & None \\
\hline & 030 & $40-50$ & Sandy Loam & $10 \mathrm{YR} 3 / 2$ & None \\
\hline & 030 & $50-60$ & Sandy Loam & $10 \mathrm{YR} 3 / 2$ & None \\
\hline & 031 & $0-10$ & $\begin{array}{l}\text { Moist Sandy } \\
\text { Loam }\end{array}$ & 10 YR 4/2 & None \\
\hline & 031 & $10-20$ & $\begin{array}{l}\text { Moist Sandy } \\
\text { Loam }\end{array}$ & 10 YR 4/2 & None \\
\hline & 031 & $20-30$ & $\begin{array}{c}\text { Moist Sandy } \\
\text { Loam }\end{array}$ & 10 YR 4/2 & None \\
\hline & 031 & $30-40$ & $\begin{array}{c}\text { Moist Sandy } \\
\text { Loam with Clay } \\
\text { Dobbs }\end{array}$ & 10 YR 4/2 & None \\
\hline & & & & 10 YR 4/2 (40-45) & None \\
\hline & 031 & $40-50$ & Clay & 10 YR 5/6 (45-50) & None \\
\hline & 032 & $0-10$ & $\begin{array}{l}\text { Friable Sandy } \\
\text { Loam }\end{array}$ & $7.5 \mathrm{YR} 3 / 2$ & None \\
\hline & 032 & $10-20$ & $\begin{array}{c}\text { Friable Sandy } \\
\text { Loam }\end{array}$ & 7.5 YR 3/2 & None \\
\hline & 032 & $20-30$ & $\begin{array}{l}\text { Loose Sandy } \\
\text { Loam }\end{array}$ & 7.5 YR 3/3 & None \\
\hline & 032 & $30-41$ & $\begin{array}{l}\text { Loose Sandy } \\
\text { Loam }\end{array}$ & $7.5 \mathrm{YR} 3 / 3$ & None \\
\hline
\end{tabular}




\section{LCCSP Archaeological Survey Shovel Test Results}

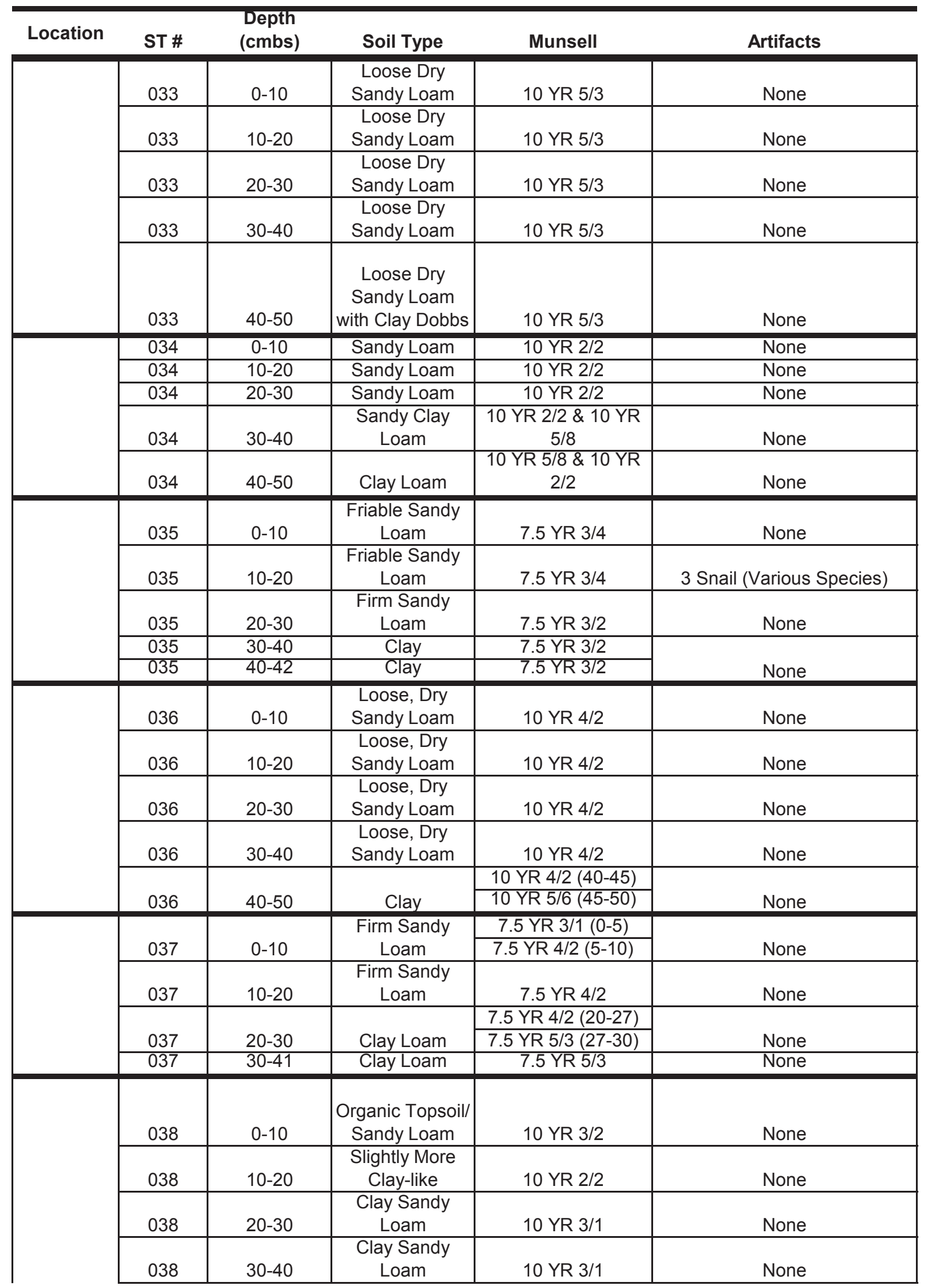


LCCSP Archaeological Survey Shovel Test Results

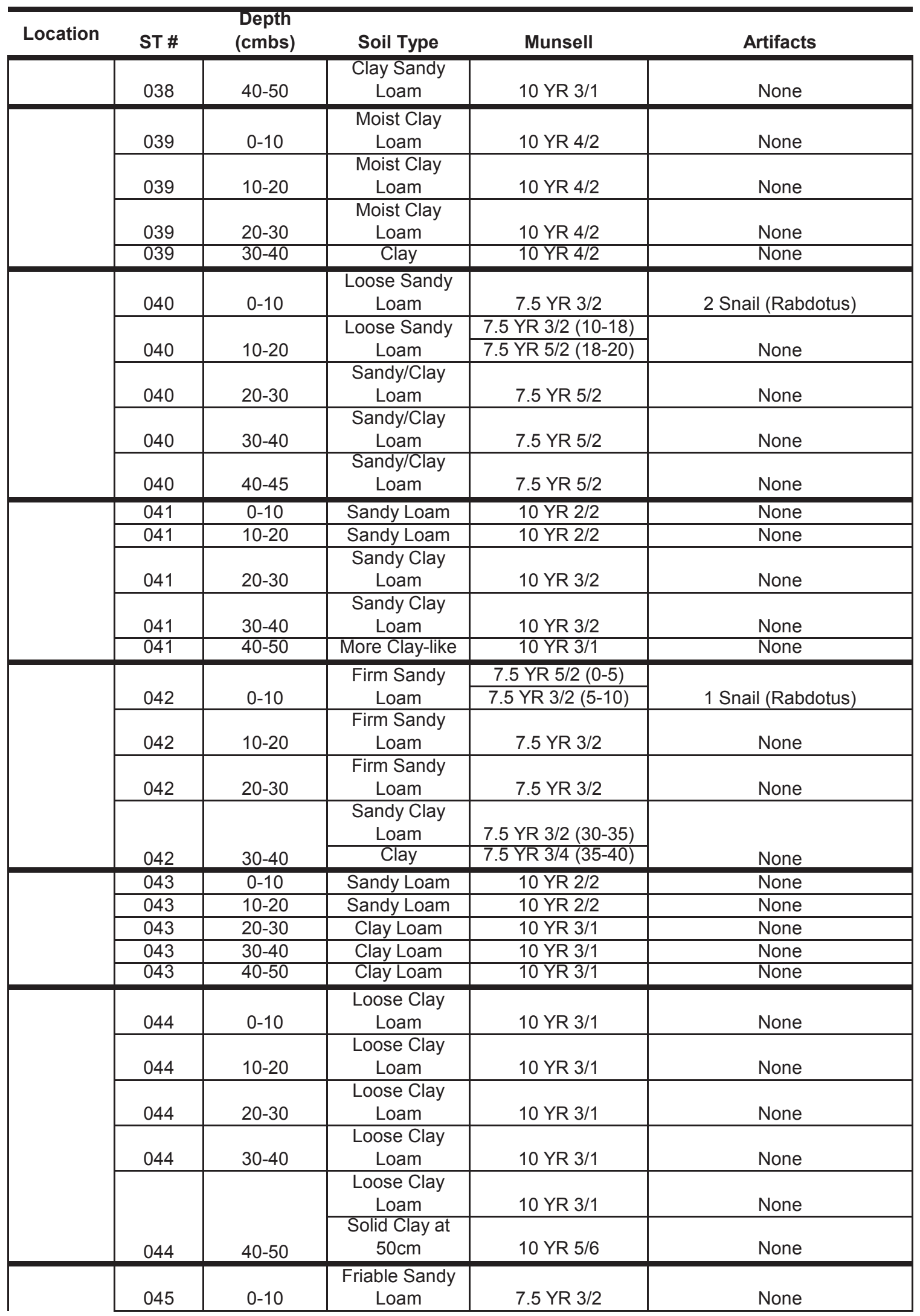




\section{LCCSP Archaeological Survey Shovel Test Results}

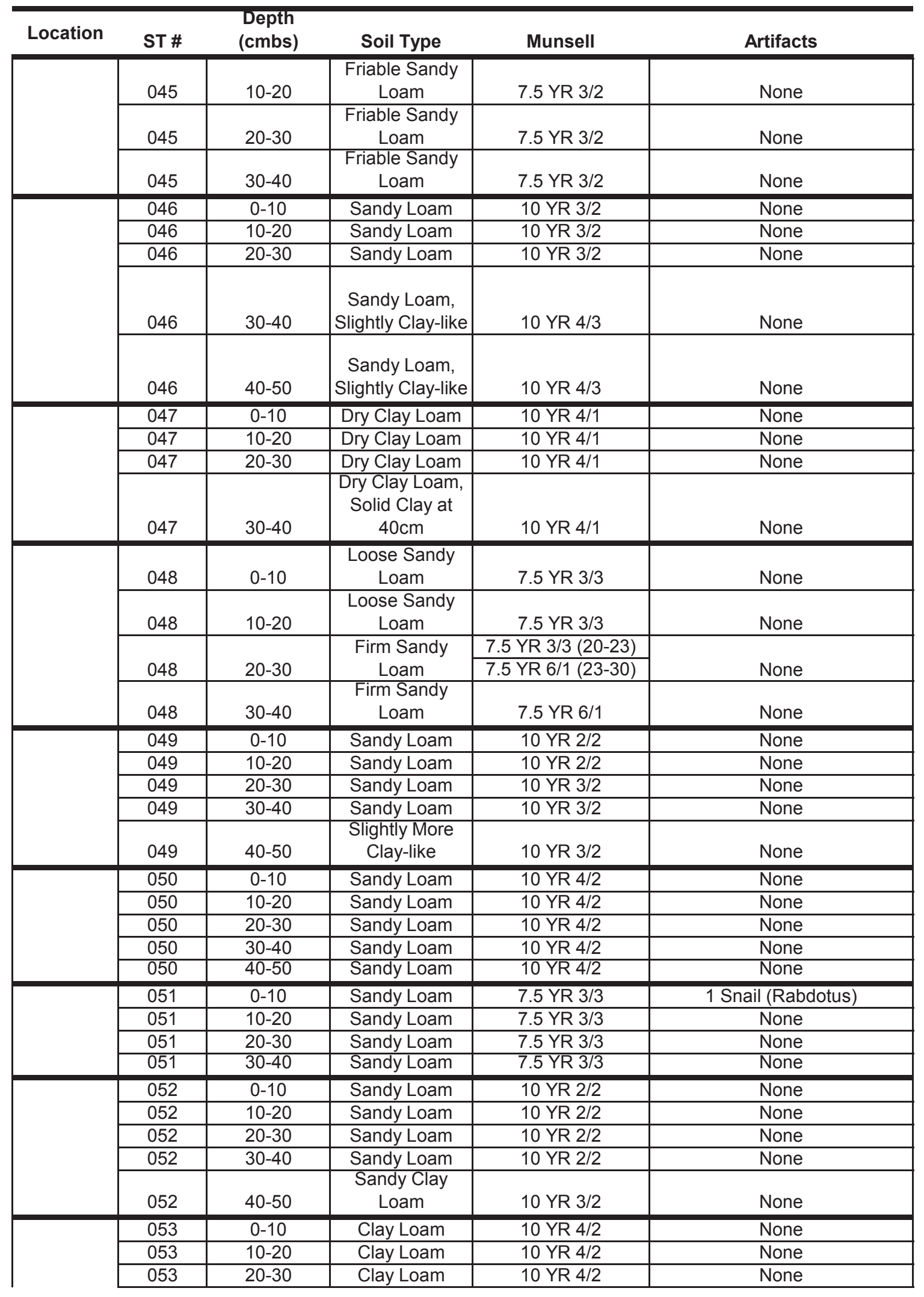




\section{LCCSP Archaeological Survey Shovel Test Results}

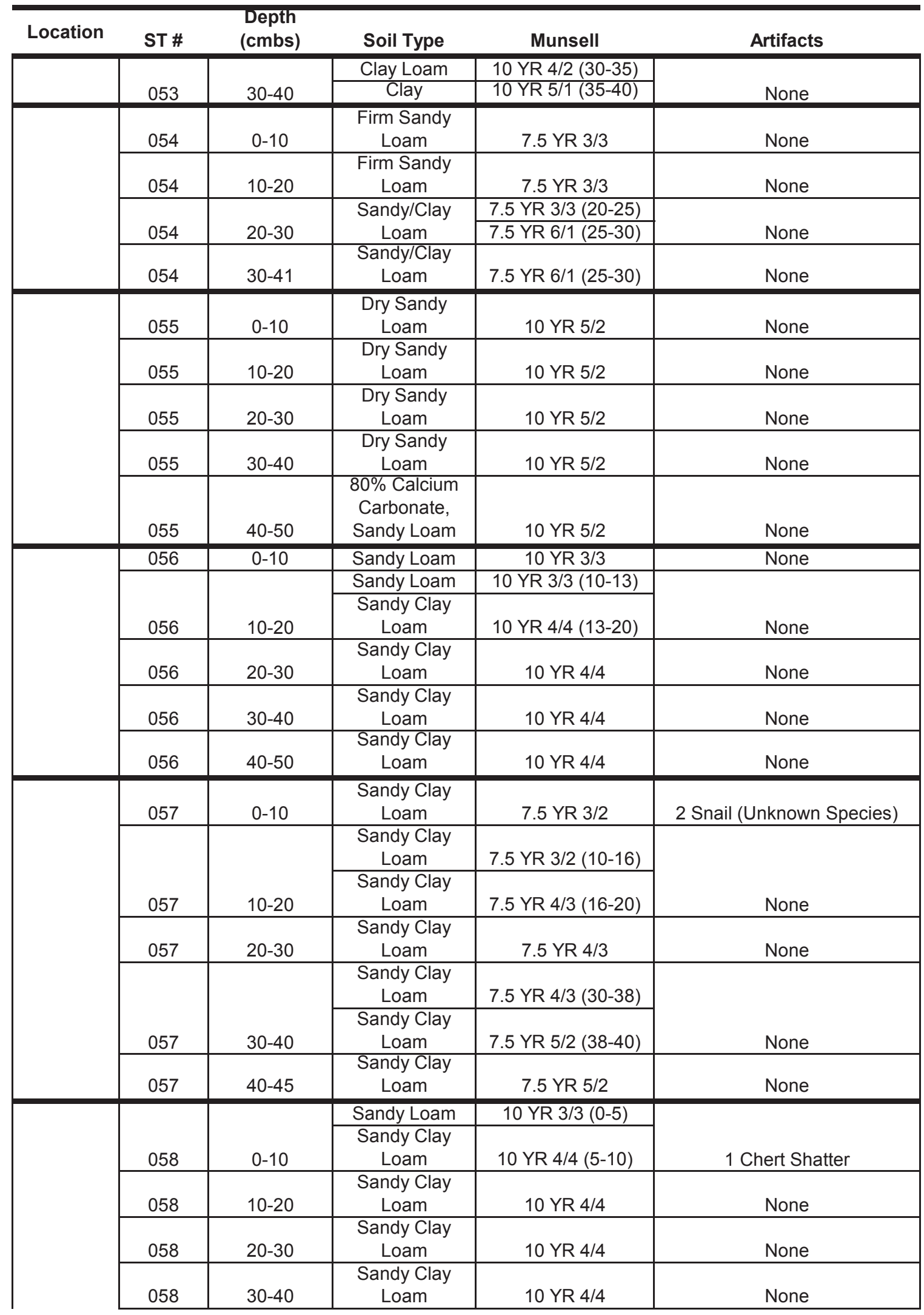


LCCSP Archaeological Survey Shovel Test Results

\begin{tabular}{|c|c|c|c|c|c|}
\hline \multirow[t]{2}{*}{ Location } & ST \# & $\begin{array}{l}\text { Depth } \\
\text { (cmbs) }\end{array}$ & Soil Type & Munsell & Artifacts \\
\hline & 058 & $40-50$ & $\begin{array}{l}\text { Sandy Clay } \\
\text { Loam }\end{array}$ & 10 YR 4/4 & None \\
\hline & 059 & $0-10$ & $\begin{array}{l}\text { Dry Sandy } \\
\text { Loam }\end{array}$ & 10 YR 5/2 & None \\
\hline & 059 & $10-20$ & $\begin{array}{l}\text { Dry Sandy } \\
\text { Loam }\end{array}$ & 10 YR 5/2 & None \\
\hline & 059 & $20-30$ & $\begin{array}{l}\text { Dry Sandy } \\
\text { Loam }\end{array}$ & 10 YR 5/2 & None \\
\hline & 059 & $30-40$ & $\begin{array}{c}\text { Dry Sandy } \\
\text { Loam }\end{array}$ & 10 YR 5/2 & None \\
\hline & 059 & $40-50$ & $\begin{array}{l}\text { Dry Sandy } \\
\text { Loam }\end{array}$ & 10 YR 5/2 & None \\
\hline & 060 & $0-10$ & $\begin{array}{c}\text { Friable Sandy } \\
\text { Loam }\end{array}$ & 7.5 YR $3 / 3$ & 7 Snail (Various Species) \\
\hline & 060 & $10-20$ & $\begin{array}{l}\text { Friable Sandy } \\
\text { Loam }\end{array}$ & 7.5 YR $3 / 3$ & 5 Snail (Various Species) \\
\hline & & & Firm Sandy & 7.5 YR 3/3 (20-25) & \multirow[b]{2}{*}{1 Snail (Rabdotus) } \\
\hline & 060 & $20-30$ & Loam & 7.5 YR 3/2 (25-30) & \\
\hline & 060 & $30-41$ & $\begin{array}{l}\text { Firm Sandy } \\
\text { Loam }\end{array}$ & $\begin{array}{l}7.5 \text { YR 3/2 (30-36) } \\
7.5 \text { YR 6/1 (36-40) }\end{array}$ & None \\
\hline & 061 & $0-10$ & Sandy Loam & 10 YR $3 / 3$ & None \\
\hline & & & Sandy Loam & 10 YR 3/3 (10-14) & \multirow[b]{2}{*}{ None } \\
\hline & 061 & $10-20$ & $\begin{array}{l}\text { Sandy Clay } \\
\text { Loam }\end{array}$ & 10 YR 4/4 (14-20) & \\
\hline & 061 & $20-30$ & $\begin{array}{c}\text { Sandy Clay } \\
\text { Loam }\end{array}$ & 10 YR 4/4 & None \\
\hline & 061 & $30-40$ & $\begin{array}{c}\text { Sandy Clay } \\
\text { Loam }\end{array}$ & 10 YR 4/4 & None \\
\hline & & & $\begin{array}{l}\text { Sandy Clay } \\
\text { Loam }\end{array}$ & 10 YR 4/4 (40-47) & \multirow[b]{2}{*}{ None } \\
\hline & 061 & $40-50$ & $\begin{array}{c}\text { Sandy Clay } \\
\text { Loam }\end{array}$ & 10 YR 5/3 (47-50) & \\
\hline & 062 & $0-10$ & $\begin{array}{c}\text { Dry Sandy } \\
\text { Loam }\end{array}$ & 10 YR 5/2 & None \\
\hline & 062 & $10-20$ & $\begin{array}{l}\text { Dry Sandy } \\
\text { Loam }\end{array}$ & 10 YR 5/2 & None \\
\hline & 062 & $20-30$ & $\begin{array}{c}\text { Dry Sandy } \\
\text { Loam }\end{array}$ & 10 YR 5/2 & None \\
\hline & 062 & $30-40$ & $\begin{array}{c}\text { Dry, Firm Sandy } \\
\text { Loam, with Clay } \\
\text { Dobbs }\end{array}$ & 10 YR 5/2 & None \\
\hline & 062 & $40-50$ & $\begin{array}{c}\text { Dry. Firm Sandy } \\
\text { Loam, with Clay } \\
\text { Dobbs }\end{array}$ & 10 YR 5/2 & None \\
\hline & 063 & $0-10$ & Sandy Loam & 10 YR 3/3 & None \\
\hline & 063 & $10-20$ & Sandy Loam & 10 YR $3 / 3$ & None \\
\hline & 063 & $20-30$ & $\begin{array}{c}\text { Sandy Clay } \\
\text { Loam }\end{array}$ & 10 YR 5/3 & None \\
\hline & 063 & $30-40$ & $\begin{array}{l}\text { Sandy Clay } \\
\text { Loam }\end{array}$ & 10 YR 5/3 & None \\
\hline & 063 & $40-50$ & $\begin{array}{l}\text { Sandy Clay } \\
\text { Loam }\end{array}$ & 10 YR 5/3 & None \\
\hline
\end{tabular}


LCCSP Archaeological Survey Shovel Test Results

\begin{tabular}{|c|c|c|c|c|c|}
\hline Location & ST \# & $\begin{array}{l}\text { Depth } \\
\text { (cmbs) }\end{array}$ & Soil Type & Munsell & Artifacts \\
\hline & 064 & $0-10$ & $\begin{array}{l}\text { Firm Sandy } \\
\text { Loam }\end{array}$ & 7.5 YR 3/4 & None \\
\hline & 064 & $10-20$ & $\begin{array}{c}\text { Firm Sandy } \\
\text { Loam }\end{array}$ & 7.5 YR 3/4 & None \\
\hline & 064 & $20-30$ & $\begin{array}{l}\text { Extremely Firm } \\
\text { Sandy Loam }\end{array}$ & 7.5 YR 3/4 & None \\
\hline & 064 & $30-41$ & $\begin{array}{l}\text { Extremely Firm } \\
\text { Sandy Loam }\end{array}$ & 7.5 YR 3/4 & None \\
\hline & 065 & $0-10$ & $\begin{array}{l}\text { Moist Clay } \\
\text { Loam }\end{array}$ & 10 YR 3/1 & None \\
\hline & 065 & $10-20$ & $\begin{array}{l}\text { Moist Clay } \\
\text { Loam }\end{array}$ & 10 YR 3/1 & None \\
\hline & 065 & $20-30$ & $\begin{array}{c}\text { Moist Clay } \\
\text { Loam }\end{array}$ & 10 YR 3/1 & None \\
\hline & 065 & $30-40$ & $\begin{array}{c}\text { Moist Clay } \\
\text { Loam, with Clay } \\
\text { Dobbs }\end{array}$ & 10 YR 3/1 & None \\
\hline & 065 & $40-50$ & $\begin{array}{c}\text { Moist Clay } \\
\text { Loam, with Clay } \\
\text { Dobbs }\end{array}$ & 10 YR 3/1 & None \\
\hline & 066 & $0-10$ & Sandy Loam & $10 \mathrm{YR} 3 / 2$ & None \\
\hline & 066 & $10-20$ & Sandy Loam & $10 \mathrm{YR} 3 / 2$ & None \\
\hline & 066 & $20-30$ & Sandy Loam & $10 \mathrm{YR} 3 / 2$ & 1 Core \\
\hline & & & & 10 YR 3/2 (30-35) & \\
\hline & 066 & $30-40$ & Sandy Loam & 10 YR 4/4 (35-40) & None \\
\hline & 066 & $40-50$ & Sandy Loam & $10 \mathrm{YR} 4 / 4$ & None \\
\hline & 066 & $50-60$ & Sandy Loam & 10 YR 4/4 & None \\
\hline & 067 & $0-10$ & $\begin{array}{l}\text { Friable Sandy } \\
\text { Loam }\end{array}$ & 7.5 YR 3/2 & $\begin{array}{c}1 \text { Snail (Helicina); } 3 \text { Snail } \\
\text { (Rabdotus) }\end{array}$ \\
\hline & 067 & $10-20$ & $\begin{array}{l}\text { Friable Sandy } \\
\text { Loam }\end{array}$ & 7.5 YR 3/2 & None \\
\hline & 067 & $20-30$ & $\begin{array}{l}\text { Loose Sandy } \\
\text { Loam }\end{array}$ & 7.5 YR 3/2 & None \\
\hline & 067 & $30-40$ & $\begin{array}{l}\text { Loose Sandy } \\
\text { Loam }\end{array}$ & 7.5 YR 3/2 & None \\
\hline \multirow{5}{*}{ 41SP116 } & 068 & $0-10$ & Sand & $10 \mathrm{YR} 4 / 2$ & None \\
\hline & 068 & $10-20$ & Sand & 10 YR 4/2 & None \\
\hline & 068 & $20-30$ & Sand & 10 YR 4/2 & None \\
\hline & 068 & $30-40$ & Sand & 10 YR 4/2 & None \\
\hline & 068 & $40-50$ & Sand & 10 YR 4/2 & None \\
\hline \multirow{7}{*}{ 41SP116 } & 069 & $0-10$ & Sandy Loam & $10 \mathrm{YR} 4 / 3$ & None \\
\hline & 069 & $10-20$ & Sandy Loam & $10 \mathrm{YR} 4 / 3$ & None \\
\hline & 069 & $20-30$ & Sandy Loam & $10 \mathrm{YR} 4 / 3$ & None \\
\hline & 069 & $30-40$ & Sandy Loam & $10 \mathrm{YR} 4 / 3$ & None \\
\hline & 069 & $40-50$ & Sandy Loam & $10 \mathrm{YR} 4 / 3$ & None \\
\hline & 069 & $50-60$ & Sandy Loam & $10 \mathrm{YR} 4 / 3$ & None \\
\hline & 069 & $60-70$ & Sandy Loam & $10 \mathrm{YR} 4 / 3$ & None \\
\hline \multirow{7}{*}{ 41SP116 } & 070 & Surface & NA & NA & 1 Debitage \\
\hline & 070 & $0-10$ & Loose Sand & 10 YR 6/4 & None \\
\hline & 070 & $10-20$ & Loose Sand & 10 YR 6/4 & None \\
\hline & 070 & $20-30$ & Loose Sand & 10 YR 6/4 & None \\
\hline & 070 & $30-40$ & Loose Sand & 10 YR 6/4 & None \\
\hline & 070 & $40-50$ & Loose Sand & 10 YR 6/4 & None \\
\hline & 070 & $50-60$ & Loose Sand & 10 YR 6/4 & None \\
\hline
\end{tabular}




\section{LCCSP Archaeological Survey Shovel Test Results}

\begin{tabular}{|c|c|c|c|c|c|}
\hline Location & ST \# & $\begin{array}{l}\text { Depth } \\
\text { (cmbs) }\end{array}$ & Soil Type & Munsell & Artifacts \\
\hline & 070 & $60-70$ & Loose Sand & 10 YR 6/4 & None \\
\hline & 070 & $70-80$ & Loose Sand & 10 YR $6 / 4$ & None \\
\hline & 070 & $80-90$ & Loose Sand & 10 YR 6/4 & None \\
\hline & 070 & $90-100$ & Loose Sand & 10 YR 6/4 & None \\
\hline \multirow{10}{*}{ 41SP116 } & 071 & $0-10$ & Sandy Loam & 10 YR 3/3 & None \\
\hline & 071 & $10-20$ & Sandy Loam & 10 YR 3/3 & None \\
\hline & 071 & $20-30$ & Sandy Loam & $10 \mathrm{YR} 3 / 3$ & None \\
\hline & 071 & $30-40$ & Sandy Loam & $10 \mathrm{YR} 3 / 3$ & None \\
\hline & 071 & $40-50$ & Sandy Loam & $10 \mathrm{YR} 3 / 3$ & None \\
\hline & 072 & $0-10$ & Sand & 10 YR 7/4 & None \\
\hline & 072 & $10-20$ & Sand & 10 YR 7/4 & None \\
\hline & 072 & $20-30$ & Sand & 10 YR 7/4 & None \\
\hline & 072 & $30-40$ & Sand & 10 YR $7 / 4$ & None \\
\hline & 072 & $40-50$ & Sand & 10 YR 7/4 & None \\
\hline & 073 & $0-10$ & $\begin{array}{l}\text { Firm Sandy } \\
\text { Loam }\end{array}$ & 7.5 YR 3/3 & None \\
\hline & 073 & $10-20$ & $\begin{array}{c}\text { Firm Sandy } \\
\text { Loam }\end{array}$ & 7.5 YR 3/3 & None \\
\hline & 073 & $20-30$ & $\begin{array}{l}\text { Firm Sandy } \\
\text { Loam }\end{array}$ & 7.5 YR 3/3 & None \\
\hline & 073 & $30-40$ & $\begin{array}{c}\text { Firm Sandy } \\
\text { Loam }\end{array}$ & 7.5 YR $3 / 3$ & None \\
\hline & 074 & $0-10$ & Sandy Loam & 10 YR $3 / 3$ & None \\
\hline & 074 & $10-20$ & Sandy Loam & $10 \mathrm{YR} 3 / 3$ & None \\
\hline & 074 & $20-30$ & Sandy Loam & $10 \mathrm{YR} 3 / 3$ & None \\
\hline & 074 & $30-40$ & Sandy Loam & $10 \mathrm{YR} 3 / 3$ & None \\
\hline & 074 & $40-50$ & Sandy Loam & $10 \mathrm{YR} 3 / 3$ & None \\
\hline & 074 & $50-60$ & Sandy Loam & $10 \mathrm{YR} 3 / 3$ & None \\
\hline & 074 & $60-70$ & Sandy Loam & $10 \mathrm{YR} 3 / 3$ & None \\
\hline \multirow{8}{*}{ 41SP228 } & 075 & $0-10$ & Dry Sand & 10 YR $6 / 3$ & 1 Chert Shatter \\
\hline & 075 & $10-20$ & Dry Sand & 10 YR $6 / 3$ & $\begin{array}{c}1 \text { Debitage; } 1 \text { Bottle; } 2 \text { Chert } \\
\text { Shatter }\end{array}$ \\
\hline & 075 & $20-30$ & Dry Sand & $10 \mathrm{YR} 6 / 3$ & 1 FCR; 1 Chert Shatter \\
\hline & 075 & $30-40$ & Dry Sand & 10 YR $6 / 3$ & None \\
\hline & 075 & $40-50$ & Dry Sand & 10 YR $6 / 3$ & 1 Debitage; 1 Snail (Rabdotus) \\
\hline & & & & 10 YR 6/3 (50-55) & \\
\hline & 075 & $50-60$ & Dry Sand & 10 YR 7/3 (55-60) & None \\
\hline & 075 & $60-70$ & Dry Sand & $10 \mathrm{YR} 7 / 3$ & None \\
\hline \multirow{7}{*}{ 41SP228 } & 076 & $0-10$ & Sandy Loam & $10 \mathrm{YR} 3 / 3$ & None \\
\hline & 076 & $10-20$ & Sandy Loam & $10 \mathrm{YR} 3 / 3$ & None \\
\hline & 076 & $20-30$ & Sandy Loam & $10 \mathrm{YR} 3 / 3$ & None \\
\hline & 076 & $30-40$ & Sandy Loam & $10 \mathrm{YR} 3 / 3$ & None \\
\hline & 076 & $40-50$ & Sandy Loam & $10 \mathrm{YR} 3 / 3$ & None \\
\hline & 076 & $50-60$ & Sandy Loam & $10 \mathrm{YR} 3 / 3$ & None \\
\hline & 076 & $60-70$ & Sandy Loam & 10 YR $3 / 3$ & None \\
\hline \multirow{4}{*}{ 41SP228 } & 077 & $0-10$ & $\begin{array}{l}\text { Dense Sandy } \\
\text { Clay }\end{array}$ & 7.5 YR 5/2 & None \\
\hline & 077 & $10-20$ & $\begin{array}{l}\text { Dense Sandy } \\
\text { Clay }\end{array}$ & 7.5 YR 5/2 & None \\
\hline & 077 & $20-30$ & $\begin{array}{l}\text { Dense Sandy } \\
\text { Clay }\end{array}$ & 7.5 YR 4/3 & None \\
\hline & 077 & $30-40$ & $\begin{array}{l}\text { Dense Sandy } \\
\text { Clay }\end{array}$ & 7.5 YR 4/3 & 2 Pebbles \\
\hline
\end{tabular}




\section{LCCSP Archaeological Survey Shovel Test Results}

\begin{tabular}{|c|c|c|c|c|c|}
\hline Location & ST \# & $\begin{array}{l}\text { Depth } \\
\text { (cmbs) }\end{array}$ & Soil Type & Munsell & Artifacts \\
\hline & 078 & $0-10$ & $\begin{array}{l}\text { Dry Sandy } \\
\text { Loam }\end{array}$ & $10 \mathrm{YR} 4 / 2$ & None \\
\hline & 078 & $10-20$ & $\begin{array}{c}\text { Dry Sandy } \\
\text { Loam }\end{array}$ & $10 \mathrm{YR} 4 / 2$ & None \\
\hline & 078 & $20-30$ & $\begin{array}{l}\text { Dry Sandy } \\
\text { Loam }\end{array}$ & 10 YR 4/2 & None \\
\hline & 078 & $30-40$ & $\begin{array}{l}\text { Dry Sandy } \\
\text { Loam }\end{array}$ & $10 \mathrm{YR} 4 / 2$ & None \\
\hline & 078 & $40-50$ & $\begin{array}{l}\text { Dry Sandy } \\
\text { Loam }\end{array}$ & 10 YR 4/2 & None \\
\hline & 079 & $0-10$ & $\begin{array}{l}\text { Firm Sandy } \\
\text { Loam }\end{array}$ & 7.5 YR 3/4 & None \\
\hline & 079 & $10-20$ & $\begin{array}{c}\text { Firm Sandy } \\
\text { Loam }\end{array}$ & 7.5 YR 3/4 & None \\
\hline & 079 & $20-30$ & $\begin{array}{l}\text { Extremely Firm } \\
\text { Sandy Loam }\end{array}$ & 7.5 YR 3/4 & None \\
\hline & 079 & $30-40$ & $\begin{array}{l}\text { Extremely Firm } \\
\text { Sandy Loam }\end{array}$ & 7.5 YR 3/4 & None \\
\hline & 079 & $40-42$ & $\begin{array}{l}\text { Extremely Firm } \\
\text { Sandy Loam }\end{array}$ & 7.5 YR 3/4 & None \\
\hline & 080 & $0-10$ & $\begin{array}{l}\text { Loose Sandy } \\
\text { Loam }\end{array}$ & 10 YR 3/3 & None \\
\hline & 080 & $10-20$ & $\begin{array}{l}\text { Loose Sandy } \\
\text { Loam }\end{array}$ & 10 YR 3/3 & None \\
\hline & 080 & $20-30$ & $\begin{array}{c}\text { Loose Sandy } \\
\text { Loam }\end{array}$ & 10 YR 3/3 & None \\
\hline & 080 & $30-40$ & $\begin{array}{l}\text { Loose Sandy } \\
\text { Loam }\end{array}$ & 10 YR 3/3 & None \\
\hline & & & Loose Sandy & 10 YR 3/3 (40-45) & \\
\hline & 080 & $40-50$ & Loam & 10 YR 4/3 (45-50) & None \\
\hline & 080 & $50-60$ & $\begin{array}{l}\text { Loose Sandy } \\
\text { Loam }\end{array}$ & $10 \mathrm{YR} 4 / 3$ & None \\
\hline \multirow{10}{*}{ 41SP235 } & 081 & $0-10$ & Sandy Loam & $10 \mathrm{YR} 3 / 3$ & 4 Debitage \\
\hline & 081 & $10-20$ & Sandy Loam & $10 \mathrm{YR} 3 / 3$ & None \\
\hline & & & & 10 YR 3/3 (20-22) & \\
\hline & 081 & $20-30$ & Sandy Loam & 10 YR 5/4 (22-30) & None \\
\hline & 081 & $30-40$ & Sandy Loam & 10 YR $5 / 4$ & None \\
\hline & 081 & $40-50$ & Sandy Loam & 10 YR 5/4 & None \\
\hline & 082 & $0-10$ & $\begin{array}{l}\text { Loose Sandy } \\
\text { Loam }\end{array}$ & 7.5 YR 3/2 & None \\
\hline & 082 & $10-20$ & $\begin{array}{c}\text { Loose Sandy } \\
\text { Loam }\end{array}$ & 7.5 YR 3/2 & None \\
\hline & 082 & $20-30$ & $\begin{array}{l}\text { Firm Sandy } \\
\text { Loam }\end{array}$ & 7.5 YR 3/2 & None \\
\hline & 082 & $30-40$ & $\begin{array}{l}\text { Firm Sandy } \\
\text { Loam }\end{array}$ & 7.5 YR 3/2 & None \\
\hline \multirow{4}{*}{ 41SP235 } & 083 & $0-10$ & Sandy Loam & $10 \mathrm{YR} 3 / 3$ & 1 Debitage \\
\hline & 083 & $10-20$ & Sandy Loam & $10 \mathrm{YR} 3 / 3$ & 1 Debitage \\
\hline & 083 & $20-30$ & $\begin{array}{l}\text { Loose Sandy } \\
\text { Loam }\end{array}$ & 10 YR 5/2 & None \\
\hline & 083 & $30-40$ & $\begin{array}{l}\text { Loose Sandy } \\
\text { Loam }\end{array}$ & 10 YR 5/2 & None \\
\hline
\end{tabular}




\section{LCCSP Archaeological Survey Shovel Test Results}

\begin{tabular}{|c|c|c|c|c|c|}
\hline Location & ST \# & $\begin{array}{l}\text { Depth } \\
\text { (cmbs) }\end{array}$ & Soil Type & Munsell & Artifacts \\
\hline & 083 & $40-50$ & $\begin{array}{l}\text { Loose Sandy } \\
\text { Loam }\end{array}$ & 10 YR 5/2 & None \\
\hline \multirow{6}{*}{ 41SP235 } & 084 & $0-10$ & Sandy Loam & 10 YR 3/3 & 1 Debitage \\
\hline & \multirow[b]{2}{*}{084} & \multirow[b]{2}{*}{$10-20$} & \multirow[b]{2}{*}{ Sandy Loam } & 10 YR 3/3 (10-12) & \multirow[b]{2}{*}{ None } \\
\hline & & & & 10 YR 4/3 (12-20) & \\
\hline & 084 & $20-30$ & Sandy Loam & $10 \mathrm{YR} 4 / 3$ & None \\
\hline & 084 & $30-40$ & Sandy Loam & $10 \mathrm{YR} 4 / 3$ & None \\
\hline & 084 & $40-50$ & Sandy Loam & $10 \mathrm{YR} 4 / 3$ & None \\
\hline \multirow{8}{*}{ 41SP235 } & 085 & $0-10$ & Sandy Loam & $10 \mathrm{YR} 3 / 3$ & 5 Debitage \\
\hline & \multirow[b]{2}{*}{085} & \multirow[b]{2}{*}{$10-20$} & \multirow[b]{2}{*}{ Sandy Loam } & 10 YR 3/3 (10-11) & \multirow[b]{2}{*}{ None } \\
\hline & & & & 10 YR 4/3 (11-20) & \\
\hline & 085 & $20-30$ & Sandy Loam & $10 \mathrm{YR} 4 / 3$ & 1 Core \\
\hline & 085 & $30-40$ & Sandy Loam & $10 \mathrm{YR} 4 / 3$ & None \\
\hline & \multirow{3}{*}{$\begin{array}{l}085 \\
085\end{array}$} & \multirow{3}{*}{$\frac{40-50}{50-55}$} & \multirow{3}{*}{$\begin{array}{l}\text { Sandy Loam } \\
\text { Sandy Loam }\end{array}$} & 10 YR 4/3 (40-48) & \multirow{3}{*}{$\frac{\text { None }}{\text { None }}$} \\
\hline & & & & 10 YR 5/3 (48-50) & \\
\hline & & & & $10 \mathrm{YR} 5 / 3$ & \\
\hline \multirow{7}{*}{ 41SP235 } & 086 & $0-10$ & Sandy Loam & 10 YR 3/3 & 1 Debitage \\
\hline & 086 & $10-20$ & Sandy Loam & $10 \mathrm{YR} 3 / 3$ & 2 Debitage; 1 Snail (Rabdotus) \\
\hline & 086 & $20-30$ & Sandy Loam & $10 \mathrm{YR} 3 / 3$ & 1 Debitage \\
\hline & 086 & $30-40$ & Sandy Loam & $10 \mathrm{YR} 3 / 3$ & None \\
\hline & 086 & $40-50$ & Sandy Loam & $10 \mathrm{YR} 3 / 3$ & 1 Debitage \\
\hline & 086 & $50-60$ & Clay Loam & $10 \mathrm{YR} 5 / 3$ & None \\
\hline & 086 & $60-65$ & Clay Loam & 10 YR 5/3 & None \\
\hline \multirow{6}{*}{$\begin{array}{l}\text { Water } \\
\text { Tower }\end{array}$} & 087 & $0-10$ & Clay Loam & 10 YR $5 / 2$ & $\begin{array}{c}4 \text { Shaped Glass (Clear w/ } \\
\text { Patina), } 2 \text { Shaped Glass } \\
\text { (Clear) }\end{array}$ \\
\hline & & & & $\begin{array}{c}10 \text { YR 5/2 with } \\
\text { Calcium Carbonate } \\
(10-15) \\
\end{array}$ & \multirow[b]{2}{*}{ None } \\
\hline & 087 & $10-20$ & Clay Loam & 10 YR 4/2 (15-20) & \\
\hline & 087 & $20-30$ & Clay Loam & $10 \mathrm{YR} 4 / 2$ & None \\
\hline & 087 & $30-40$ & Clay Loam & $10 \mathrm{YR} 4 / 2$ & None \\
\hline & 087 & $40-50$ & Clay & $10 \mathrm{YR} 3 / 2$ & None \\
\hline \multirow{5}{*}{$\begin{array}{l}\text { Water } \\
\text { Tower }\end{array}$} & 088 & $0-10$ & $\begin{array}{l}\text { Loose Sandy } \\
\text { Loam }\end{array}$ & 7.5 YR 4/3 & $\begin{array}{c}5 \text { Charcoal; } 12 \text { Chert Pebbles; } \\
64 \text { Gravel - Calichecrete }\end{array}$ \\
\hline & 088 & $10-20$ & $\begin{array}{l}\text { Loose Sandy } \\
\text { Loam }\end{array}$ & 7.5 YR 4/3 & 4 Charcoal; 5 Chert Pebbles \\
\hline & \multirow[b]{2}{*}{088} & \multirow[b]{2}{*}{$20-30$} & $\begin{array}{l}\text { Calcium } \\
\text { Carbonate \& } \\
\text { Gravel }\end{array}$ & 7.5 YR 8/1 (20-25) & \multirow[b]{2}{*}{16 Charcoal } \\
\hline & & & $\begin{array}{l}\text { Friable Sandy } \\
\text { Loam }\end{array}$ & 7.5 YR 4/2 (25-30) & \\
\hline & 088 & $30-40$ & $\begin{array}{c}\text { Friable Sandy } \\
\text { Loam }\end{array}$ & 7.5 YR 4/2 & 2 Charcoal; 1 Pebble \\
\hline
\end{tabular}




\section{LCCSP Archaeological Survey Shovel Test Results}

\begin{tabular}{|c|c|c|c|c|c|}
\hline Location & ST \# & $\begin{array}{l}\text { Depth } \\
\text { (cmbs) }\end{array}$ & Soil Type & Munsell & Artifacts \\
\hline \multirow{4}{*}{ 41SP235 } & 089 & $0-10$ & $\begin{array}{c}\text { Friable Sandy } \\
\text { Loam }\end{array}$ & 7.5 YR 3/3 & None \\
\hline & 089 & $10-20$ & $\begin{array}{l}\text { Friable Sandy } \\
\text { Loam }\end{array}$ & $7.5 \mathrm{YR} 3 / 3$ & None \\
\hline & 089 & $20-30$ & $\begin{array}{l}\text { Firm Sandy } \\
\text { Loam }\end{array}$ & $7.5 \mathrm{YR} 3 / 3$ & None \\
\hline & 089 & $30-40$ & $\begin{array}{l}\text { Firm Sandy } \\
\text { Loam }\end{array}$ & $7.5 \mathrm{YR} 3 / 3$ & None \\
\hline \multirow{5}{*}{ 41SP235 } & 090 & $0-10$ & $\begin{array}{l}\text { Friable Sandy } \\
\text { Loam }\end{array}$ & 7.5 YR 3/2 & None \\
\hline & 090 & $10-20$ & $\begin{array}{l}\text { Friable Sandy } \\
\text { Loam }\end{array}$ & 7.5 YR 3/2 & None \\
\hline & 090 & $20-30$ & $\begin{array}{c}\text { Firm Sandy } \\
\text { Loam }\end{array}$ & 7.5 YR 3/2 & None \\
\hline & & & $\begin{array}{l}\text { Firm Sandy } \\
\text { Loam }\end{array}$ & 7.5 YR 3/2 (30-37) & \\
\hline & 090 & $30-40$ & $\begin{array}{l}\text { Very Firm } \\
\text { Sandy Clay }\end{array}$ & 7.5 YR 6/2 (37-40) & None \\
\hline \multirow{5}{*}{ 41SP235 } & 091 & $0-10$ & Sandy Loam & 10 YR $3 / 3$ & $\begin{array}{l}2 \text { Debitage; } 1 \text { Chert Chunk, } \\
\text { Riverworn; } 1 \text { Snail (Rabdotus) }\end{array}$ \\
\hline & 091 & $10-20$ & Sandy Loam & 10 YR 5/4 & None \\
\hline & 091 & $20-30$ & Sandy Loam & $10 \mathrm{YR} 5 / 4$ & None \\
\hline & 091 & $30-40$ & Sandy Loam & $10 \mathrm{YR} 5 / 4$ & None \\
\hline & 091 & $40-50$ & Sandy Loam & 10 YR 5/4 & None \\
\hline \multirow{5}{*}{ 41SP235 } & 092 & $0-10$ & Sandy Loam & $10 \mathrm{YR} 4 / 3$ & None \\
\hline & 092 & $10-20$ & Sandy Loam & $10 \mathrm{YR} 4 / 3$ & None \\
\hline & 092 & $20-30$ & Sandy Loam & $10 \mathrm{YR} 4 / 3$ & 1 Debitage \\
\hline & 092 & $30-40$ & Sandy Loam & $10 \mathrm{YR} 4 / 3$ & None \\
\hline & 092 & $40-50$ & Sandy Loam & 10 YR 4/3 & None \\
\hline \multirow{6}{*}{ 41SP235 } & 093 & $0-10$ & Sandy Loam & $10 \mathrm{YR} 3 / 3$ & None \\
\hline & & & & 10 YR 3/3 (10-15) & \\
\hline & 093 & $10-20$ & Sandy Loam & 10 YR 4/3 (15-20) & None \\
\hline & 093 & $20-30$ & Sandy Loam & $10 \mathrm{YR} 4 / 3$ & None \\
\hline & 093 & $30-40$ & Sandy Loam & $10 \mathrm{YR} 4 / 3$ & None \\
\hline & 093 & $40-50$ & Sandy Loam & $10 \mathrm{YR} 4 / 3$ & None \\
\hline \multirow{4}{*}{ 41SP235 } & 094 & $0-10$ & $\begin{array}{l}\text { Friable Sandy } \\
\text { Loam }\end{array}$ & 7.5 YR 3/3 & None \\
\hline & 094 & $10-20$ & $\begin{array}{l}\text { Friable Sandy } \\
\text { Loam }\end{array}$ & 7.5 YR 3/3 & None \\
\hline & 094 & $20-30$ & $\begin{array}{l}\text { Firm Sandy } \\
\text { Loam }\end{array}$ & 7.5 YR $3 / 3$ & 1 Core \\
\hline & 094 & $30-40$ & $\begin{array}{l}\text { Firm Sandy } \\
\text { Loam }\end{array}$ & 7.5 YR $3 / 3$ & None \\
\hline \multirow{5}{*}{ 41SP235 } & 095 & $0-10$ & Sandy Loam & 10 YR 4/3 & 1 Debitage \\
\hline & 095 & $10-20$ & Sandy Loam & 10 YR 4/3 & None \\
\hline & 095 & $20-30$ & Sandy Loam & $10 \mathrm{YR} 4 / 3$ & None \\
\hline & 095 & $30-40$ & Sandy Loam & $10 \mathrm{YR} 4 / 3$ & None \\
\hline & 095 & $40-50$ & Sandy Loam & $10 \mathrm{YR} 4 / 3$ & None \\
\hline \multirow{2}{*}{ 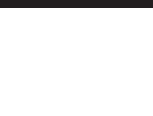 } & 096 & Surface & $\mathrm{NA}$ & $\mathrm{NA}$ & 1 Tested Cobble \\
\hline & 096 & $0-10$ & Sandy Loam & $10 \mathrm{YR} 3 / 3$ & 3 Debitage; 4 Snail (Rabdotus) \\
\hline
\end{tabular}


LCCSP Archaeological Survey Shovel Test Results

\begin{tabular}{|c|c|c|c|c|c|}
\hline Location & ST \# & $\begin{array}{l}\text { Depth } \\
\text { (cmbs) }\end{array}$ & Soil Type & Munsell & Artifacts \\
\hline \multirow{5}{*}{ 41SP235 } & & & & 10 YR $3 / 3(10-17)$ & \\
\hline & 096 & $10-20$ & Sandy Loam & 10 YR 4/3 (17-20) & 1 Debitage \\
\hline & 096 & $20-30$ & Sandy Loam & 10 YR 4/3 & None \\
\hline & 096 & $30-40$ & Sandy Loam & $10 \mathrm{YR} 4 / 3$ & None \\
\hline & 096 & $40-50$ & Sandy Loam & 10 YR 4/3 & None \\
\hline \multirow{4}{*}{ 41SP235 } & 097 & $0-10$ & $\begin{array}{l}\text { Firm Sandy } \\
\text { Loam }\end{array}$ & 7.5 YR 3/3 & None \\
\hline & 097 & $10-20$ & $\begin{array}{c}\text { Firm Sandy } \\
\text { Loam }\end{array}$ & 7.5 YR 3/3 & None \\
\hline & 097 & $20-30$ & $\begin{array}{c}\text { Firm Sandy } \\
\text { Loam }\end{array}$ & 7.5 YR 3/3 & None \\
\hline & 097 & $30-41$ & $\begin{array}{l}\text { Firm Sandy } \\
\text { Loam }\end{array}$ & 7.5 YR 3/3 & None \\
\hline \multirow{5}{*}{ 41SP234 } & 098 & $0-10$ & $\begin{array}{l}\text { Extremely Firm } \\
\text { Sandy Loam }\end{array}$ & 7.5 YR 4/2 & None \\
\hline & 098 & $10-20$ & $\begin{array}{l}\text { Extremely Firm } \\
\text { Sandy Loam }\end{array}$ & 7.5 YR 4/2 & None \\
\hline & 098 & $20-30$ & $\begin{array}{c}\text { Firm Sandy } \\
\text { Loam }\end{array}$ & 7.5 YR 3/3 & None \\
\hline & 098 & $30-40$ & $\begin{array}{c}\text { Firm Sandy } \\
\text { Loam }\end{array}$ & 7.5 YR 3/3 & None \\
\hline & 098 & $40-42$ & $\begin{array}{l}\text { Firm Sandy } \\
\text { Loam }\end{array}$ & 7.5 YR $3 / 3$ & None \\
\hline \multirow{6}{*}{ 41SP227 } & 099 & $0-10$ & Sand & 10 YR $5 / 3$ & None \\
\hline & 099 & $10-20$ & Sand & 10 YR 5/3 & None \\
\hline & 099 & $20-30$ & Sandy Clay & 10 YR 4/2 & 1 Core \\
\hline & 099 & $30-40$ & Sandy Clay & 10 YR 4/2 & None \\
\hline & 099 & $40-50$ & Sandy Clay & 10 YR 4/2 & 1 Debitage \\
\hline & 099 & $50-53$ & Bedrock & Bedrock & None \\
\hline \multirow{3}{*}{ 41SP234 } & 100 & $0-10$ & Sandy Loam & $10 \mathrm{YR} 3 / 3$ & None \\
\hline & \multirow[b]{2}{*}{100} & \multirow[b]{2}{*}{$10-20$} & Sandy Loam & $10 \mathrm{YR} 3 / 3$ & None \\
\hline & & & Caliche Bedrock & 7.5 YR 7/1 & None \\
\hline & 101 & $0-10$ & \begin{tabular}{|c|} 
Sandy Loam \\
Mixed with \\
Gravel Fill \\
\end{tabular} & 10 YR 4/3 & None \\
\hline & 101 & $10-20$ & $\begin{array}{c}\text { Sandy Loam } \\
\text { Mixed with } \\
\text { Gravel Fill } \\
\end{array}$ & 10 YR 4/3 & None \\
\hline & 101 & $20-30$ & $\begin{array}{c}\text { Sandy Loam } \\
\text { Mixed with } \\
\text { Gravel Fill } \\
\end{array}$ & 10 YR 4/3 & None \\
\hline & 101 & $30-40$ & $\begin{array}{l}\text { Sandy Loam } \\
\text { Mixed with } \\
\text { Gravel Fill }\end{array}$ & 10 YR 4/3 & None \\
\hline & 102 & Surface & $\mathrm{NA}$ & NA & 1 Bivalve (Freshwater Clam) \\
\hline & 102 & $0-10$ & $\begin{array}{c}\text { Firm Sandy } \\
\text { Loam }\end{array}$ & 7.5 YR $3 / 3$ & None \\
\hline & 102 & $10-20$ & $\begin{array}{l}\text { Firm Sandy } \\
\text { Loam }\end{array}$ & 7.5 YR 3/3 & None \\
\hline
\end{tabular}




\section{LCCSP Archaeological Survey Shovel Test Results}

\begin{tabular}{|c|c|c|c|c|c|}
\hline Location & ST \# & $\begin{array}{l}\text { Depth } \\
\text { (cmbs) }\end{array}$ & Soil Type & Munsell & Artifacts \\
\hline & 102 & $20-30$ & $\begin{array}{l}\text { Firm Sandy } \\
\text { Loam }\end{array}$ & 7.5 YR 3/3 & None \\
\hline & 102 & $30-40$ & $\begin{array}{l}\text { Firm Sandy } \\
\text { Loam }\end{array}$ & 7.5 YR 3/3 & 1 Snail (Rabdotus) \\
\hline & 102 & $40-42$ & $\begin{array}{l}\text { Firm Sandy } \\
\text { Loam }\end{array}$ & 7.5 YR $3 / 3$ & None \\
\hline & 103 & $0-10$ & Sandy Loam & 10 YR $3 / 3$ & None \\
\hline & 103 & $10-20$ & Sandy Loam & $10 \mathrm{YR} 3 / 3$ & None \\
\hline & 103 & $20-30$ & Sandy Loam & $10 \mathrm{YR} 3 / 3$ & None \\
\hline & 103 & $30-37$ & Sandy Loam & $10 \mathrm{YR} 3 / 3$ & None \\
\hline \multirow{6}{*}{$41 \mathrm{SP} 178$} & 104 & $0-10$ & Sand & $10 \mathrm{YR} 5 / 3$ & None \\
\hline & 104 & $10-20$ & Sand & $10 \mathrm{YR} 5 / 3$ & 1 Shaped Glass \\
\hline & 104 & $20-30$ & Sand & $10 \mathrm{YR} 5 / 3$ & 1 Debitage; 1 Round Nail \\
\hline & 104 & $30-40$ & Sand & $10 \mathrm{YR} 5 / 3$ & 3 Debitage \\
\hline & 104 & $40-50$ & Sand & $10 \mathrm{YR} 5 / 3$ & None \\
\hline & 104 & $50-60$ & Sand & $10 \mathrm{YR} 5 / 3$ & None \\
\hline \multirow{5}{*}{ 41SP178 } & 105 & $0-10$ & Sandy Loam & $10 \mathrm{YR} 4 / 2$ & $\begin{array}{c}\text { Brick; } 4 \text { Mortar; } 12 \\
\text { Calichecrete; } 15 \text { Charcoal; } 4 \\
\text { Clear w/ Patina Shaped Glass; } \\
2 \text { Amber w/ Patin Shaped } \\
\text { Glass; } 17 \text { Debitage; } 10 \text { Round } \\
\text { Nails; } 3 \text { Wire Round Nails; } 35 \\
\text { Metal Scrap; } 1 \text { Slag }\end{array}$ \\
\hline & 105 & $10-20$ & Sandy Loam & $10 \mathrm{YR} 3 / 3$ & $\begin{array}{c}9 \text { Brick; } 4 \text { Mortar; } 10 \\
\text { Calichecrete; } 1 \text { Charcoal; } 2 \\
\text { Round Nail }\end{array}$ \\
\hline & 105 & $20-30$ & Sandy Loam & 10 YR 3/3 & $\begin{array}{c}9 \text { Brick; } 6 \text { Mortar; } 6 \\
\text { Calichecrete }\end{array}$ \\
\hline & 105 & $30-40$ & Sandy Loam & $10 \mathrm{YR} 3 / 3$ & $\begin{array}{c}2 \text { Calichecrete; } 1 \text { Brick; } 1 \\
\text { Round Nail }\end{array}$ \\
\hline & 105 & $40-48$ & Sandy Loam & $10 \mathrm{YR} 3 / 3$ & 3 Brick \\
\hline \multirow{6}{*}{ 41SP178 } & 106 & $0-10$ & $\begin{array}{l}\text { Firm Sandy } \\
\text { Loam }\end{array}$ & 7.5 YR 5/4 & $\begin{array}{l}2 \text { Round Nail; } 1 \text { Wire Round } \\
\text { Nail; }\end{array}$ \\
\hline & 106 & $10-20$ & $\begin{array}{c}\text { Firm Sandy } \\
\text { Loam }\end{array}$ & 7.5 YR $5 / 4$ & None \\
\hline & \multirow[b]{2}{*}{106} & \multirow[b]{2}{*}{$20-30$} & \multirow[b]{2}{*}{$\begin{array}{c}\text { Firm Sandy } \\
\text { Loam \& Caliche }\end{array}$} & 7.5 YR 5/4 (Soil) & \multirow[b]{2}{*}{ None } \\
\hline & & & & 7.5 YR 7/1 (Caliche) & \\
\hline & & & & \begin{tabular}{|l|}
7.5 YR 5/4 (Soil) \\
\end{tabular} & \multirow[b]{2}{*}{2 Round Nail } \\
\hline & 106 & $30-40$ & $\begin{array}{c}\text { Firm Sandy } \\
\text { Loam \& Caliche }\end{array}$ & 7.5 YR 7/1 (Caliche) & \\
\hline \multirow{5}{*}{ 41SP202 } & 107 & $0-10$ & Sandy Loam & 10 YR $6 / 2$ & None \\
\hline & 107 & $10-20$ & Sandy Loam & $10 \mathrm{YR} 6 / 2$ & None \\
\hline & 107 & $20-30$ & Clay Loam & 10 YR $5 / 2$ & None \\
\hline & \multirow[b]{2}{*}{107} & \multirow[b]{2}{*}{$30-40$} & Clay Loam & 10 YR 5/2 (30-35) & \multirow[b]{2}{*}{ None } \\
\hline & & & Clay & 10 YR 3/1 (35-40) & \\
\hline \multirow{6}{*}{ 41SP202 } & & & Sandy Loam & 10 YR 3/2 (0-8) & \multirow[b]{2}{*}{ None } \\
\hline & 108 & $0-10$ & Loam & 10 YR 3/1 (8-10) & \\
\hline & 108 & $10-20$ & Loam & $10 \mathrm{YR} 3 / 1$ & None \\
\hline & 108 & $20-30$ & Loam & 10 YR 3/1 & None \\
\hline & 108 & $30-40$ & Loam & 10 YR 3/1 & None \\
\hline & 108 & $40-50$ & Loam & $10 \mathrm{YR} 3 / 1$ & None \\
\hline & 109 & $0-10$ & $\begin{array}{l}\text { Firm Sandy } \\
\text { Loam }\end{array}$ & 7.5 YR 3/2 & None \\
\hline
\end{tabular}


LCCSP Archaeological Survey Shovel Test Results

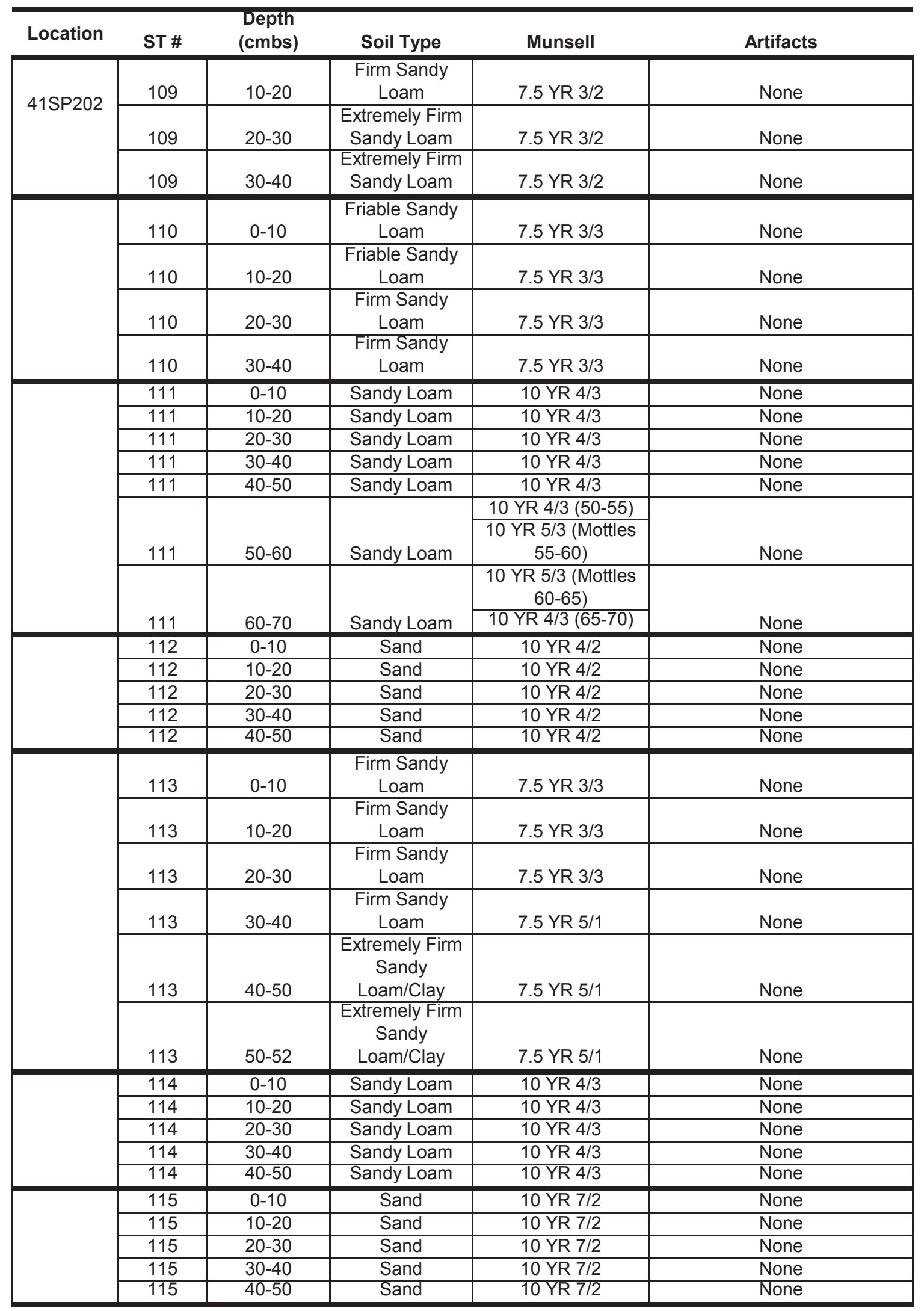




\section{LCCSP Archaeological Survey Shovel Test Results}

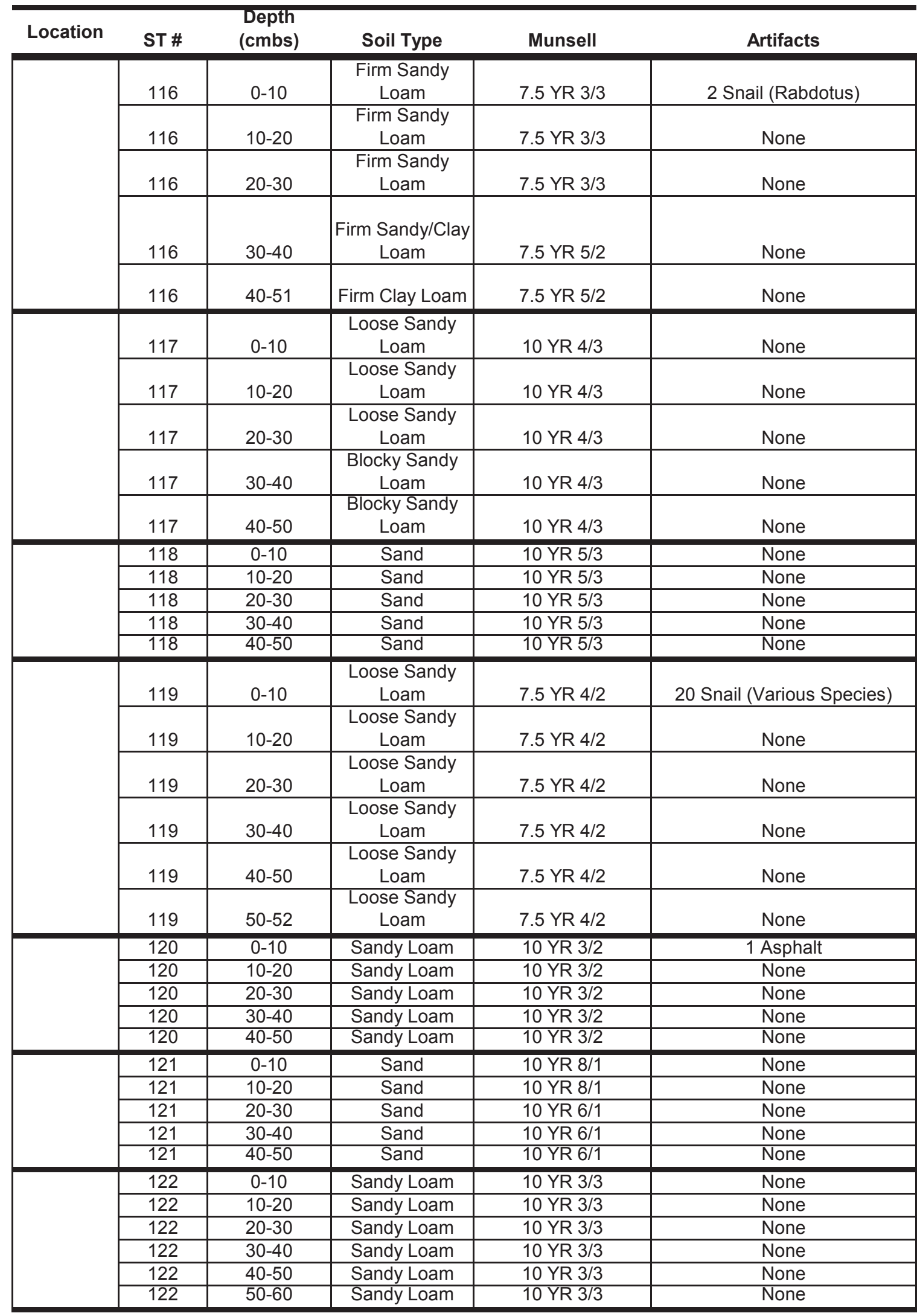




\section{LCCSP Archaeological Survey Shovel Test Results}

\begin{tabular}{|c|c|c|c|c|c|}
\hline Location & ST \# & $\begin{array}{l}\text { Depth } \\
\text { (cmbs) }\end{array}$ & Soil Type & Munsell & Artifacts \\
\hline \multirow{6}{*}{ 41SP202 } & 123 & $0-10$ & Sandy Loam & $10 \mathrm{YR} 5 / 3$ & None \\
\hline & 123 & $10-20$ & Sandy Loam & $10 \mathrm{YR} 5 / 3$ & None \\
\hline & 123 & $20-30$ & Sandy Loam & $10 \mathrm{YR} 5 / 3$ & None \\
\hline & \multirow{3}{*}{$\frac{123}{123}$} & \multirow{3}{*}{$\frac{30-40}{40-50}$} & Sandy Loam & 10 YR 5/3 (30-35) & \multirow[b]{2}{*}{ None } \\
\hline & & & Clay Loam & 10 YR 4/2 (35-40) & \\
\hline & & & Clay Loam & $10 \mathrm{YR} 4 / 2$ & None \\
\hline \multirow{8}{*}{ 41SP202 } & 124 & Surface & NA & NA & 1 Scraper; 2 Debitage \\
\hline & 124 & $0-10$ & Sandy Loam & 10 YR $6 / 2$ & None \\
\hline & \multirow[b]{2}{*}{124} & \multirow[b]{2}{*}{$10-20$} & \multirow[b]{2}{*}{ Sandy Loam } & 10 YR 6/2 (10-11) & \multirow[b]{2}{*}{ None } \\
\hline & & & & 10 YR 3/2 (11-20) & \\
\hline & 124 & $20-30$ & Sandy Loam & $10 \mathrm{YR} 3 / 2$ & None \\
\hline & 124 & $30-40$ & Sandy Loam & $10 \mathrm{YR} 3 / 2$ & None \\
\hline & \multirow[b]{2}{*}{124} & \multirow[b]{2}{*}{$40-50$} & Sandy Loam & 10 YR 3/2 (40-42) & \multirow[b]{2}{*}{ None } \\
\hline & & & $\begin{array}{l}\text { Sandy Loam w/ } \\
\text { Calcium } \\
\text { Carbonate } \\
\text { Nodules }\end{array}$ & 10 YR 3/2 (42-50) & \\
\hline \multirow{6}{*}{ 41SP202 } & \multirow[b]{2}{*}{125} & \multirow[b]{2}{*}{$0-10$} & \multirow{2}{*}{$\begin{array}{c}\text { Friable Sandy } \\
\text { Loam }\end{array}$} & 7.5 YR 3/3 (0-9) & \multirow[b]{2}{*}{ None } \\
\hline & & & & 7.5 YR 5/1 (9-10) & \\
\hline & 125 & $10-20$ & $\begin{array}{c}\text { Friable Sandy } \\
\text { Loam } \\
\end{array}$ & 7.5 YR 5/1 & None \\
\hline & 125 & $20-30$ & $\begin{array}{c}\text { Extremely Firm } \\
\text { Sandy Clay }\end{array}$ & 7.5 YR 5/1 & None \\
\hline & 125 & $30-40$ & $\begin{array}{l}\text { Extremely Firm } \\
\text { Sandy Clay }\end{array}$ & 7.5 YR 5/1 & None \\
\hline & 125 & $40-50$ & $\begin{array}{l}\text { Extremely Firm } \\
\text { Sandy Clay }\end{array}$ & 7.5 YR 5/1 & None \\
\hline & 126 & $0-10$ & Sand & $10 \mathrm{YR} 5 / 2$ & None \\
\hline & 126 & $10-20$ & Sand & $10 \mathrm{YR} 5 / 2$ & None \\
\hline & 126 & $20-30$ & Sand & 10 YR 5/2 & None \\
\hline & 126 & $30-40$ & Sand & 10 YR 5/2 & None \\
\hline & 126 & $40-50$ & Sand & 10 YR 5/2 & None \\
\hline & 127 & $0-10$ & Sandy Loam & $10 \mathrm{YR} 4 / 3$ & None \\
\hline & 127 & $10-20$ & Sandy Loam & 10 YR 4/3 & None \\
\hline & 127 & $20-30$ & Sandy Loam & 10 YR 4/3 & None \\
\hline & 127 & $30-40$ & Sandy Loam & $10 \mathrm{YR} 4 / 3$ & None \\
\hline & 127 & $40-50$ & Sandy Loam & $10 \mathrm{YR} 4 / 3$ & None \\
\hline & 127 & $50-55$ & Sandy Loam & 10 YR 4/3 & None \\
\hline & 128 & $0-10$ & $\begin{array}{l}\text { Loose Sandy } \\
\text { Loam }\end{array}$ & 7.5 YR 3/3 & $\begin{array}{l}14 \text { Snail (Rabdotus); } 7 \text { Snail } \\
\text { (Helicina) }\end{array}$ \\
\hline & 128 & $10-20$ & $\begin{array}{l}\text { Loose Sandy } \\
\text { Loam }\end{array}$ & 7.5 YR 3/3 & None \\
\hline & 128 & $20-30$ & $\begin{array}{l}\text { Friable Sandy } \\
\text { Loam }\end{array}$ & 7.5 YR 3/3 & None \\
\hline & 128 & $30-40$ & $\begin{array}{c}\text { Friable Sandy } \\
\text { Loam }\end{array}$ & 7.5 YR 3/3 & None \\
\hline & 128 & $40-50$ & $\begin{array}{l}\text { Friable Sandy } \\
\text { Loam }\end{array}$ & 7.5 YR 3/3 & None \\
\hline & 128 & $50-52$ & $\begin{array}{c}\text { Friable Sandy } \\
\text { Loam }\end{array}$ & 7.5 YR 3/3 & None \\
\hline 41SP234 & $\begin{array}{c}\text { CCC } \\
\text { Complex }\end{array}$ & Surface & NA & NA & 1 Calichecrete; 1 Bottle \\
\hline
\end{tabular}




\section{LCCSP Archaeological Survey Shovel Test Results}

\begin{tabular}{|c|c|c|c|c|c|}
\hline Location & ST \# & $\begin{array}{l}\text { Depth } \\
\text { (cmbs) }\end{array}$ & Soil Type & Munsell & Artifacts \\
\hline & $\begin{array}{c}\text { Site } \\
\text { 41SP202 }\end{array}$ & Surface & NA & NA & 1 Biface; 1 Scraper \\
\hline & $\begin{array}{c}\text { Site } \\
\text { 41SP228 }\end{array}$ & Surface & NA & NA & 1 Scraper; 1 Debitage \\
\hline
\end{tabular}


Appendix B

Artifact Catalog 


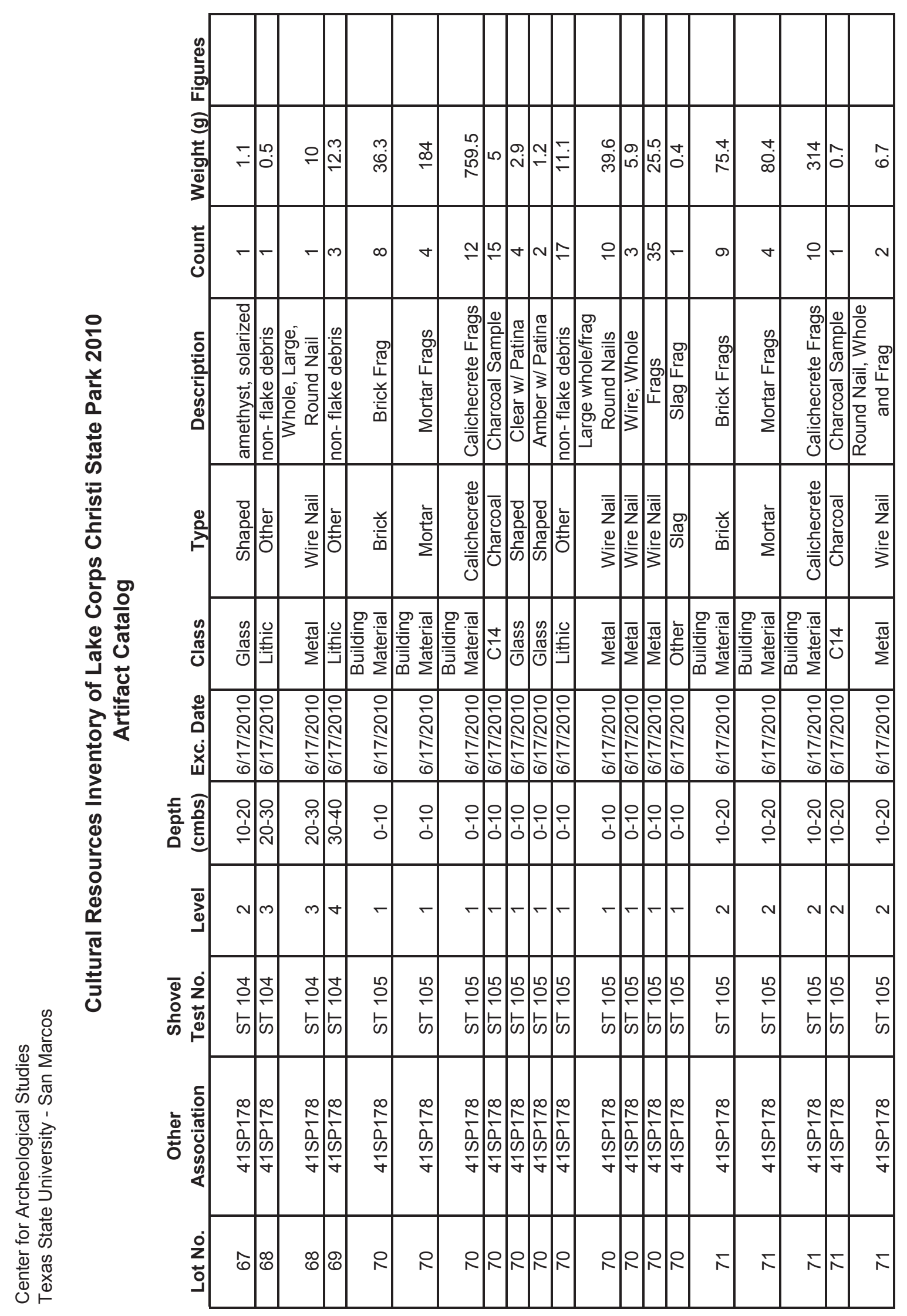




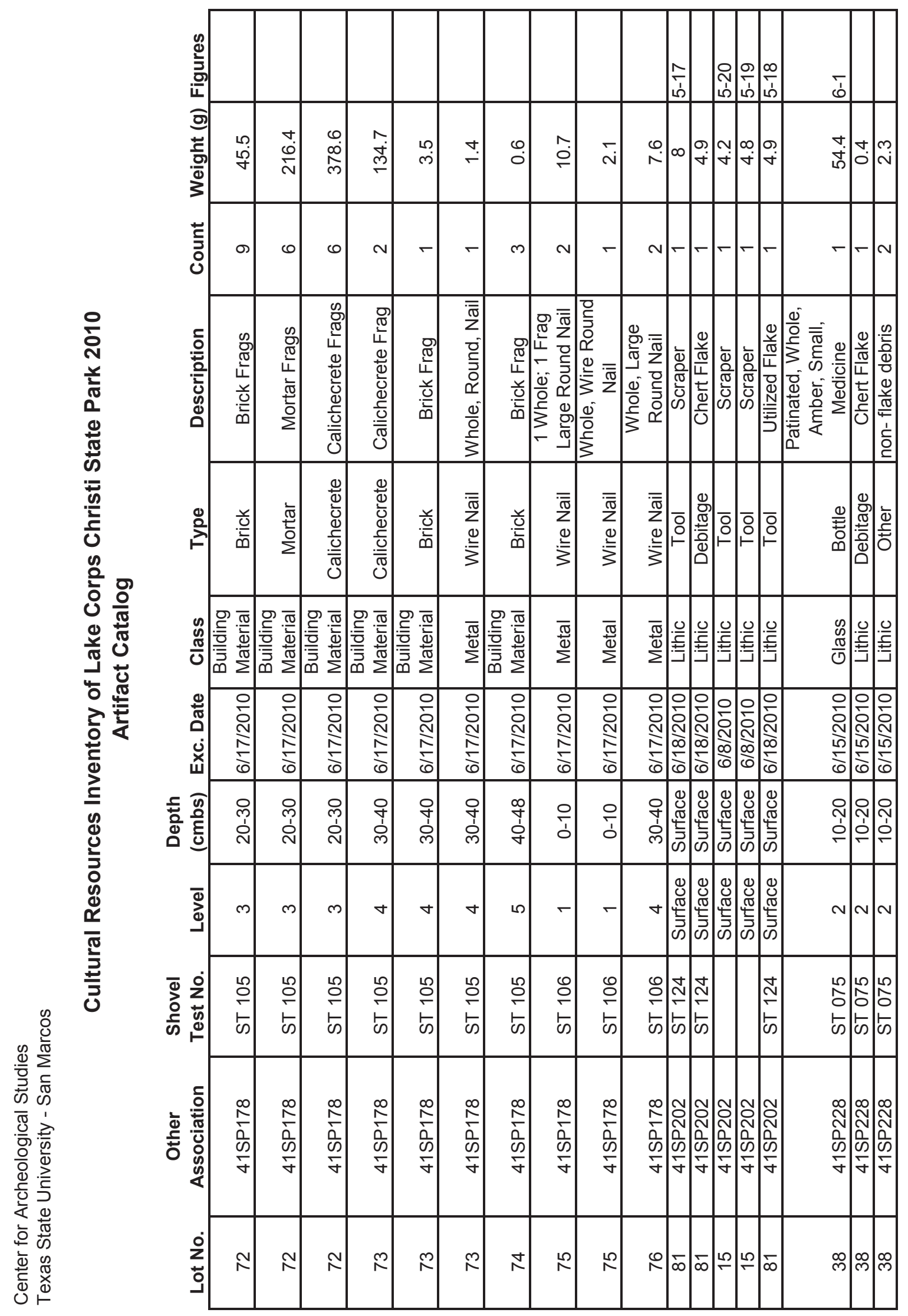




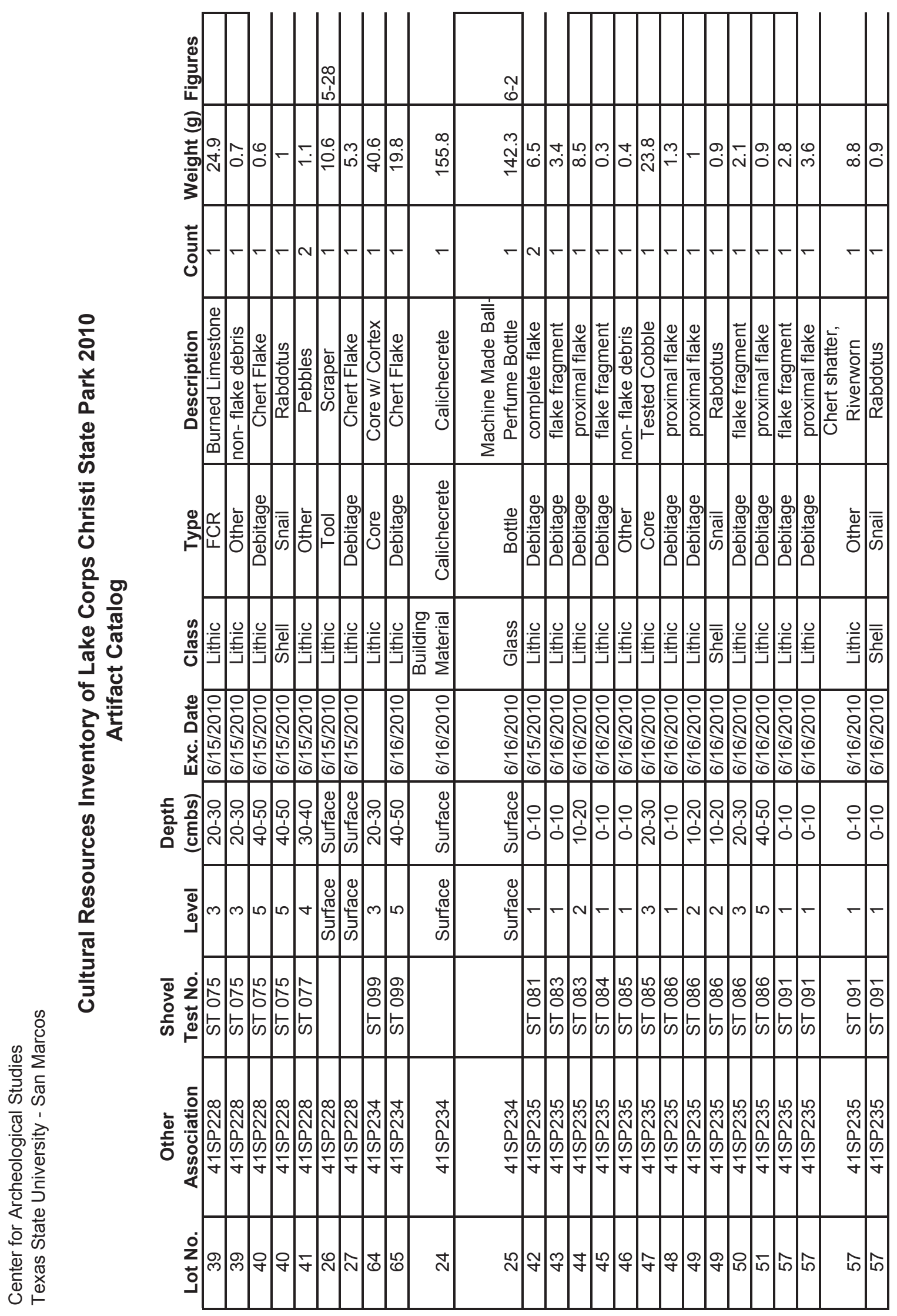




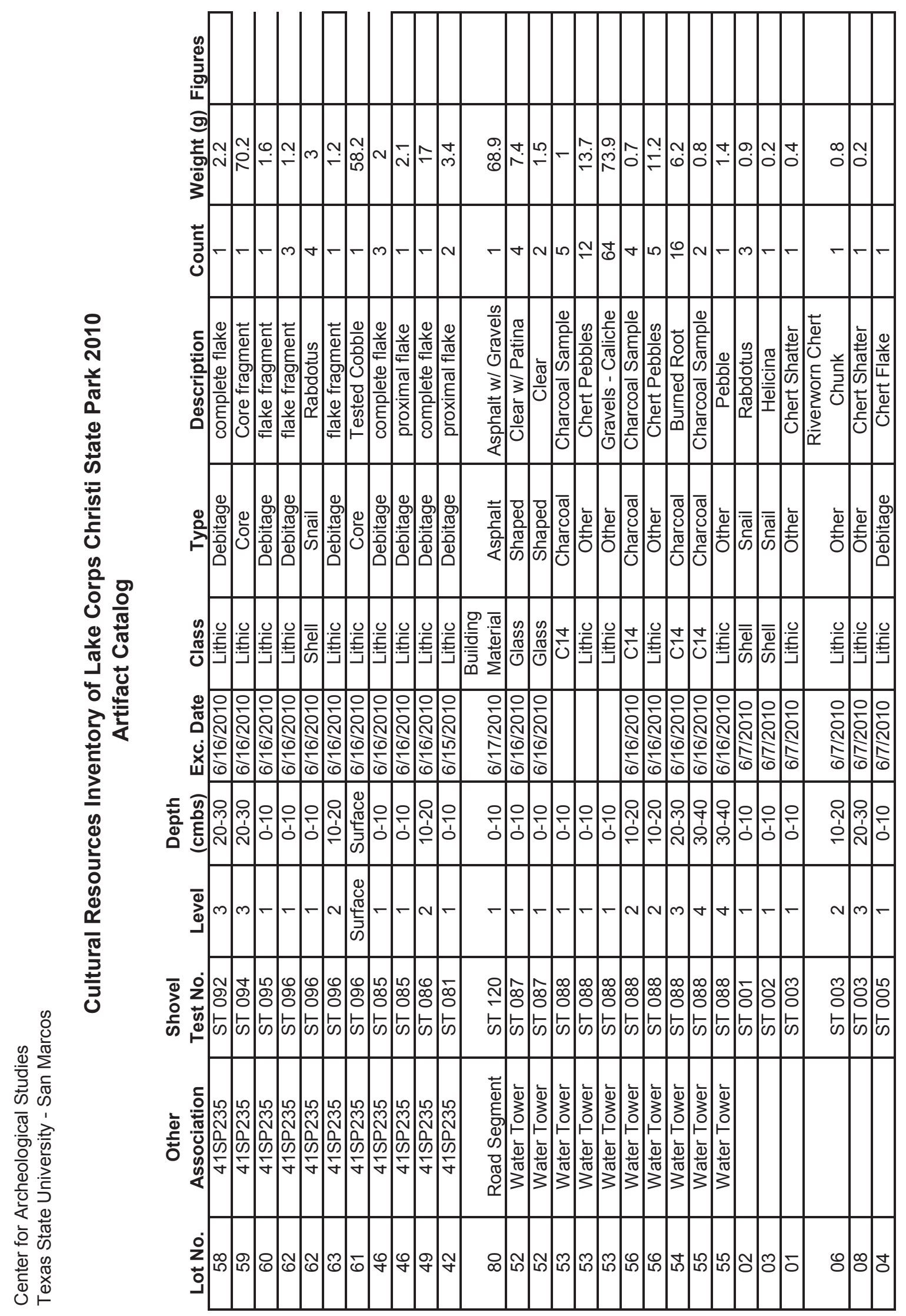




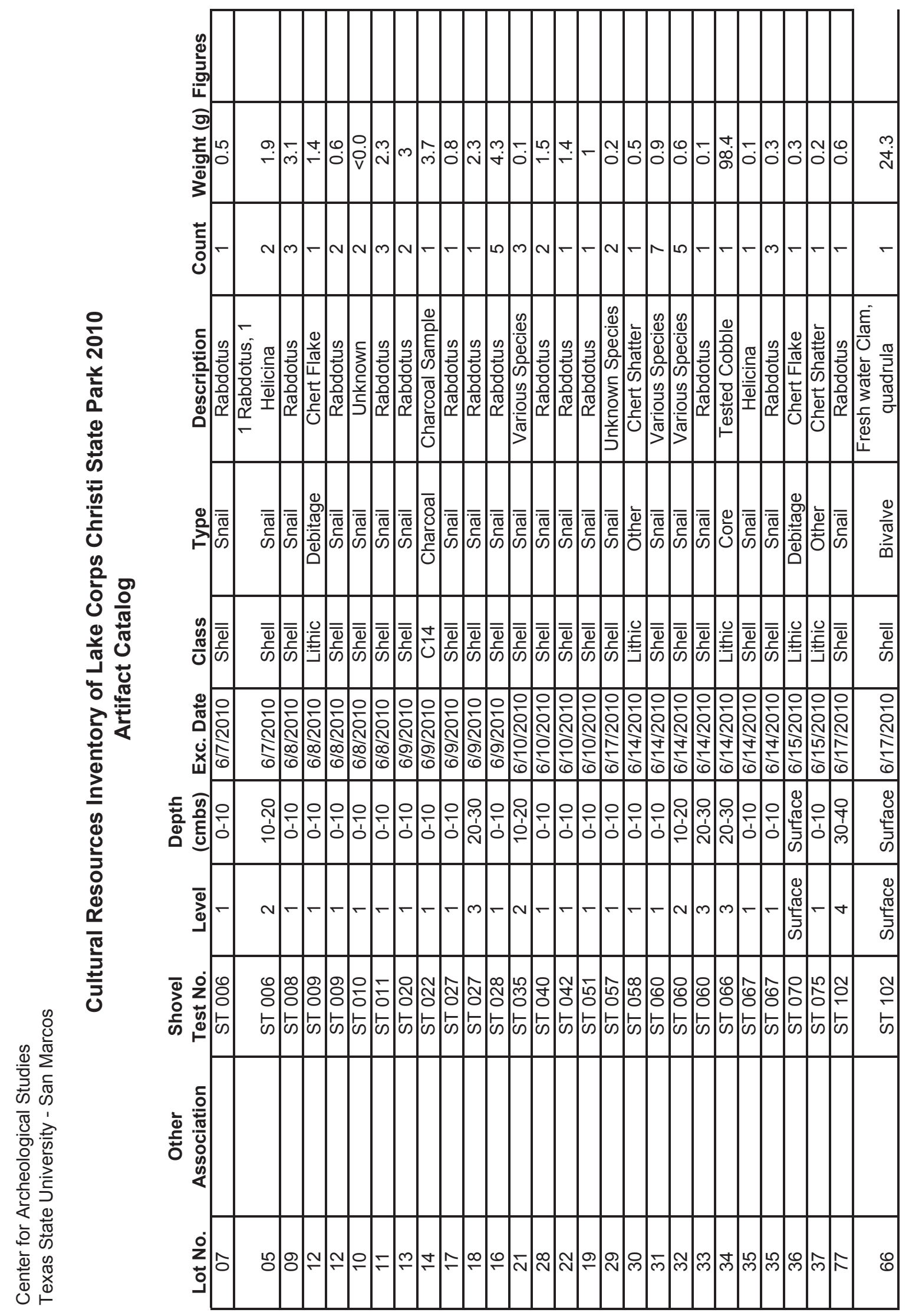




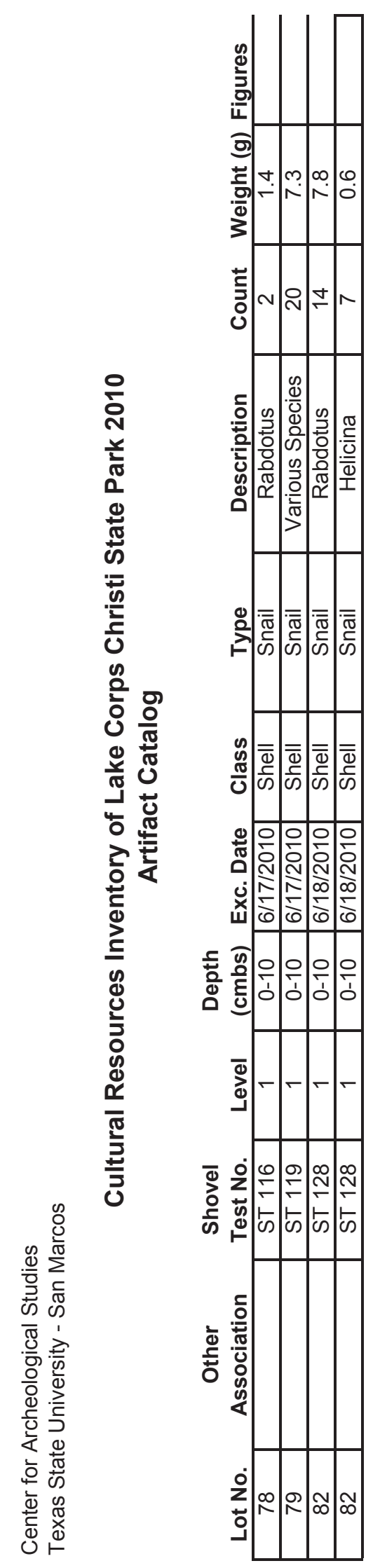




\section{Appendix C \\ State of Texas Archeological Site Data Forms \\ (Restricted Access Only)}


Appendix D

MAPS

(Restricted Access Only) 


Appendix E
Site Maps
(Restricted ACCESS ONly)


FIGURE D-1. REDACTED

Figure D-1. Previously recorded sites within Lake Corpus Christi State Park. 


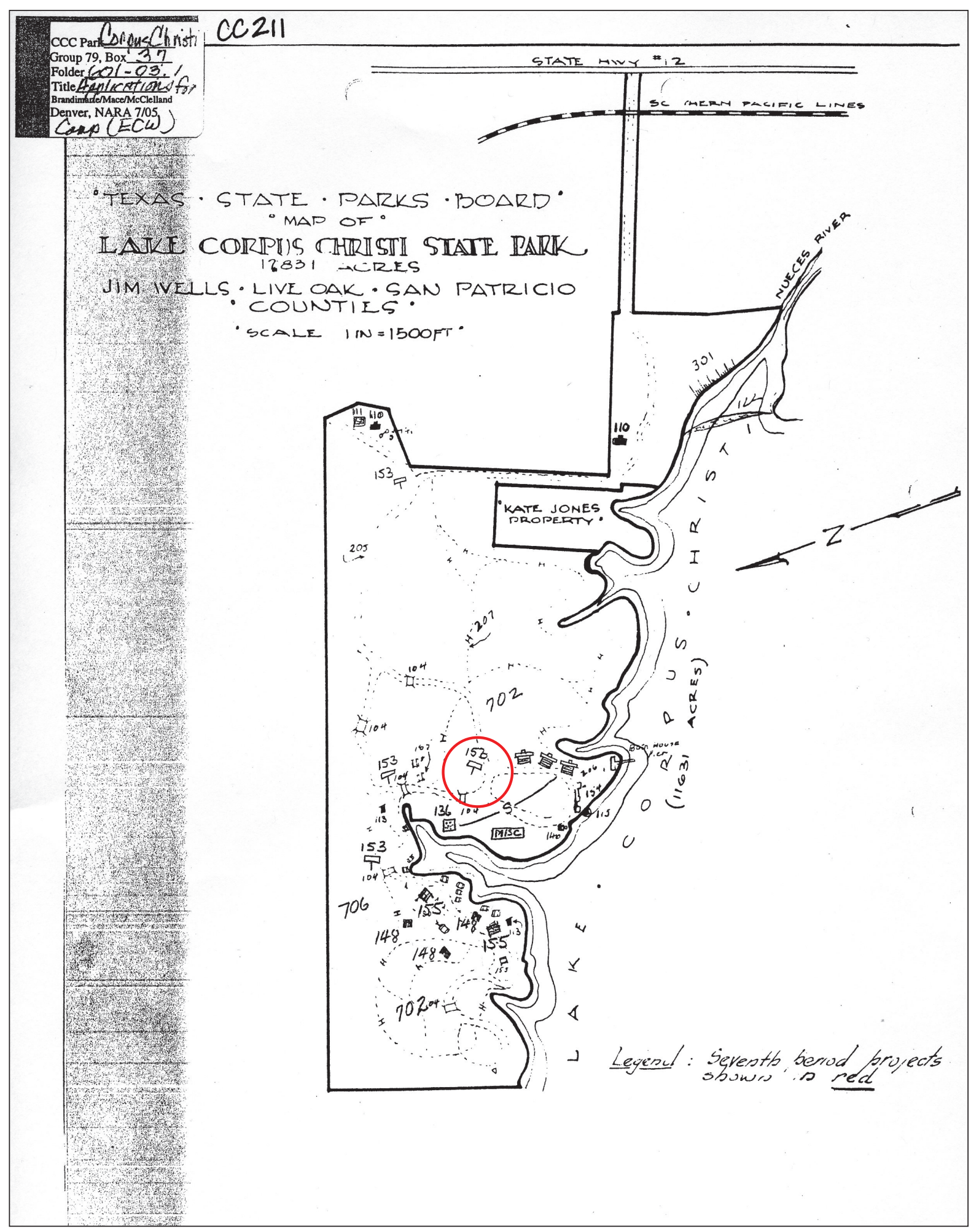

Figure D-2. CCC map suggesting a possible structure at 41SP178. 
FIGURE D-3. REDACTED

Figure D-3. Eastern portion of the surveyed area. 


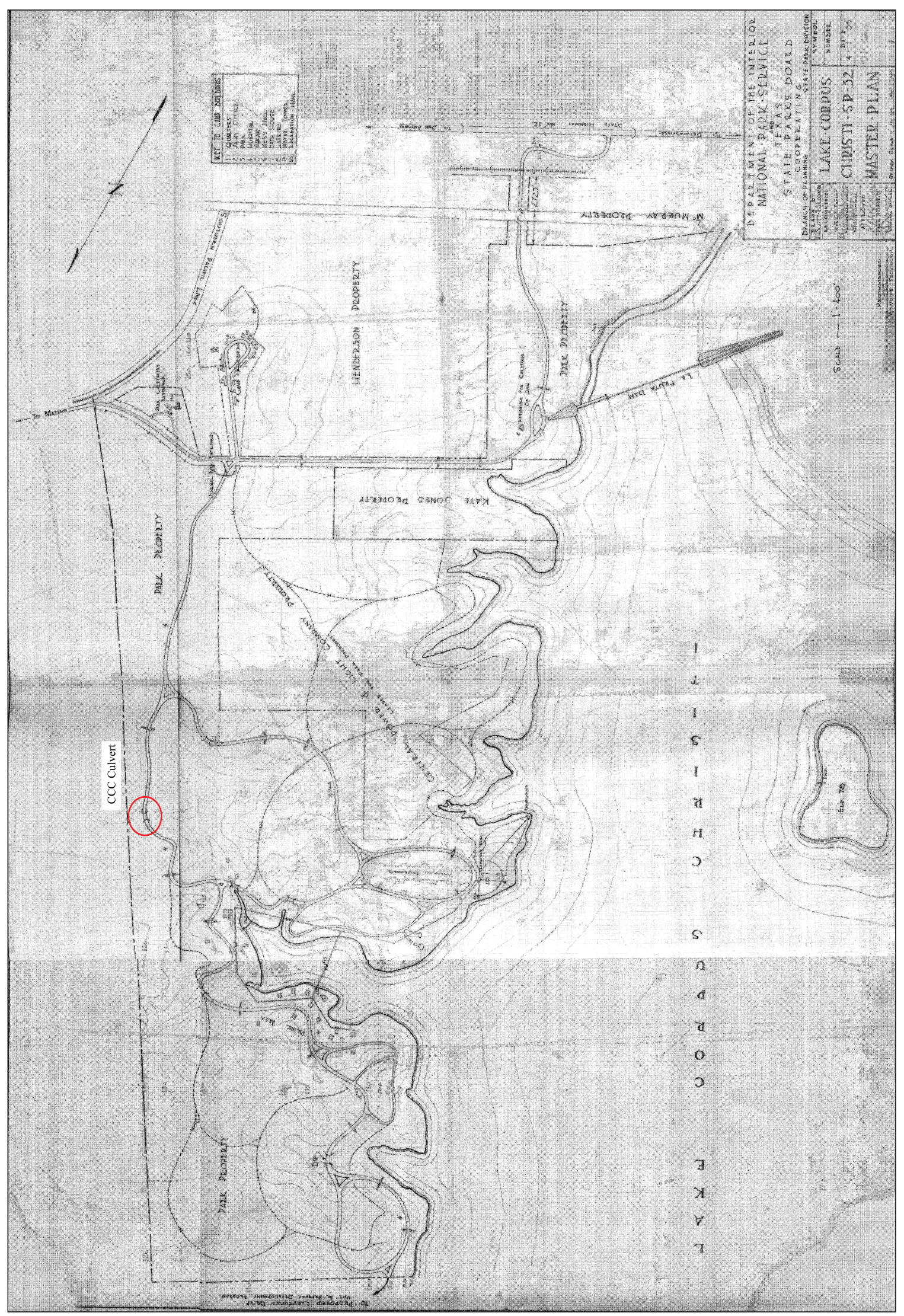

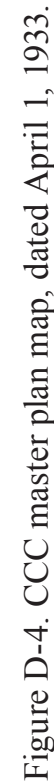


FIGURE D-5. REDACTED

Figure D-5. Western portion of surveyed area. 
FIGURE D-6. REDACTED

Figure D-6. Overlay of historic CCC Map (Item No. CC211 TPWD Lake Corpus Christi State Park CCC files) on current map of park with noted site boundaries. 

FIGURE E-1. REDACTED

Figure E-1. Site map of 41SP116. 
FIIGURE E-2. REDACTED

Figure E-2. Site map of 41SP178. 
FIGURE E-3. REDACTED

Figure E-3. Site map of 41SP202. 
FIGURE E-4. REDACTED

Figure E-4. Site map of 41SP227. 
FIGURE E-5. REDACTED

Figure E-5. Site map of 41SP228. 
FIGURE E-6. REDACTED

Figure E-6. Site map of 41SP235. 
FIGURE E-7. REDACTED

Figure E-7. Site map of 41SP234. 
FIGURE E-8. REDACTED

Figure E-8. Culvert location map. 
FIGURE E-9. REDACTED

Figure E-9. Water tower location map. 
FIGURE E-10. REDACTED

Figure E-10. Location map of possible CCC road. 
